\title{
Sistemas Tutores Inteligentes e sua Aplicação em Empresas
}

\author{
Mary Yorinori
}

\author{
DISSERTAÇÃO APRESENTADA AO \\ INSTITUTO DE MATEMÁTICA E ESTATÍSTICA DA \\ UNIVERSIDADE DE SÃO PAULO PARA \\ OBTENÇÃO DO GRAU DE MESTRE EM \\ MATEMÁTICA APLICADA
}

Área de Concentração: Ciência da Computação

Orientador: Flávio Soares Corrêa da Silva

São Paulo, março de 2000

Durante a elaboração deste trabalho, a autora recebeu apoio financeiro do CNPq 


\title{
Sistemas Tutores Inteligentes e sua Aplicação em Empresas
}

\author{
Este exemplar corresponde à redação final da dissertação \\ devidamente corrigida e defendida por Mary Yorinori \\ e aprovada pela comissão julgadora.
}

São Paulo, 30 de agosto de 2000.

Banca examinadora:

- Prof. Dr. Flávio Soares Corrêa da Silva (orientador) - MAC-IME / USP

- Profa. Dra. Leliane Nunes de Barros - MAC-IME / USP

- Profa. Dra. Iole de Freitas Druck - MAT-IME / USP 
Aos meus pais,

Akiko e Tadashi 


\section{Agradecimentos}

Aos meus pais, pelo apoio, amor e incentivo incondicionais que me permitiram batalhar para alcançar o mestrado.

Aos meus irmãos Marcos, Marcia e Mauricio, e ao meu cunhado Adilson pela força e pelo incentivo, mesmo estando distantes.

Ao professor Flávio Soares Corrêa da Silva, pela paciência e pela dedicação na orientação durante a elaboração desta dissertação.

Ao professor José Augusto, pela orientação no início do programa de mestrado.

Aos professores Arnaldo Mandel, Cristina e Yoshiko, pelo apoio no final do mestrado.

Às professoras Iole e Leliane, pela participação na banca de defesa, pelas sugestões e pelas críticas.

Ao Luis, por toda a força, apoio, companheirismo e pelos bons momentos que passamos.

Aos meus amigos do IME, Cao, Jorge, Flávio e Seiiti, pela ajuda que me deram e pelos momentos de descontração que tornaram o mestrado mais ameno.

Ao Pinho e à Francisca, pelo apoio em todos os momentos em que precisei.

Aos meus tios Artur e Rosa e aos meus primos Alessandro, Robson, Michelle e Jessica, que me receberam com carinho desde o início do mestrado.

Aos meus queridos amigos Maurício, Carla, Sérgio, Karina e Patricia, pela força e incentivo em todos os momentos.

À minha prima Harumi, pelos conselhos e pela força nos momentos mais difíceis.

Aos pesquisadores Tom Murray, Lucia Giraffa, Richard Blumenthal, Minoru Kiyama, Menachem Jona, Alex Kass e Randall Sparks, pela troca de informações e pelo envio de material. 


\section{Resumo}

Com a finalidade de superar as limitações impostas pelos métodos tradicionais de ensino, os STIs surgiram no meio acadêmico e mostraram-se capazes de oferecer instruções de maneira semelhante a um instrutor humano.

Na última década, passaram a ser utilizados para treinamento de funcionários em empresas, como forma de proporcionar o conhecimento e as habilidades necessárias ao aperfeiçoamento profissional.

A crescente demanda por formas cada vez mais eficientes de treinamento tem favorecido a entrada dos STIs neste meio, levando à busca por metodologias e ferramentas de autoria que visam facilitar o desenvolvimento destes sistemas.

Neste trabalho apresentamos o nosso estudo sobre os aspectos mais importantes a serem considerados no desenvolvimento de STIs, tais como usabilidade, independência de domínio, múltiplas estratégias de ensino, reusabilidade e interoperabilidade. Em seguida apresentamos alguns sistemas existentes e identificamos áreas de aplicação dentro de empresas.

Questões sobre a avaliação de STIs e de ferramentas de desenvolvimento são abordadas de maneira a apontar alguns parâmetros considerados na determinação de sua eficiência. Embora os métodos de avaliação não sigam padrões determinados, de uma maneira geral, seus resultados permitem avaliar tanto o desempenho do sistema no ensino quanto a eficiência das ferramentas de desenvolvimento. 


\begin{abstract}
With the purpose of overcoming the limitations imposed by traditional training methods, ITSs emerged in the academic environment and showed their ability to teach in a way similar to human instructors.

In the last decade, they had been used for in-company employee training as a means to provide knowledge and skills required on the job.The increasing need for more efficient methods of training contributed for placing ITSs in the business environment, which has lead to the search for methodologies and authoring tools which make system development easier.

In this study, we present our research on the most important aspects to be considered in ITSs' development, such as usability, domain independence, multiple teaching strategies, reusability and interoperability. Afterwards, we present some existing systems and identify application areas inside companies.

Issues about ITSs' and development tools' evaluation are covered in such a way that we point out a few parameters considered in determining their efficiency. Although evaluation methods usually do not follow standards, their outcomes allow evaluation of the system's performance in training and the development tools' efficiency.
\end{abstract}




\section{Conteúdo}

1 Introduçã

2 Evolução dos Sistemas baseados em IAC aos STIs................................................. 3

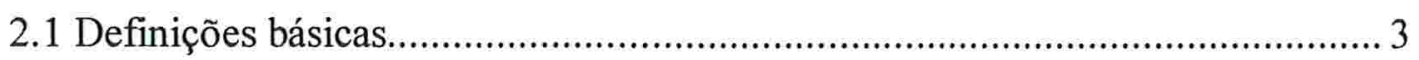

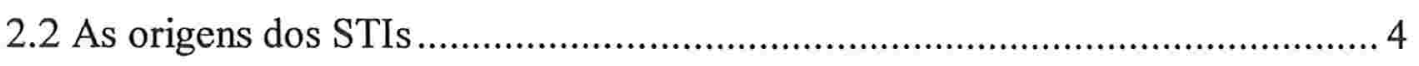

2.3 Surgimento dos Sistemas Tutores Inteligentes................................................ 6

2.4 STIs e Inteligência Artificial ...................................................................... 7

2.5 STIs e Sistemas Especialistas ................................................................... 9

2.6 Grupos de sistemas voltados a ensino e treinamento........................................ 10

3 Arquiteturas de STIs ..................................................................................................... 11

3.1 Arquitetura Básica de um STI .................................................................. 11

3.1.1 Conceito de Domínio ....................................................................... 13

3.1.2 Modelo do Especialista ou Modelo do Domínio ................................... 14

3.1.3 Modelo do Aluno ou Usuário ........................................................... 15

3.1.4 Modelo Tutorial ou Instrucional........................................................ 18

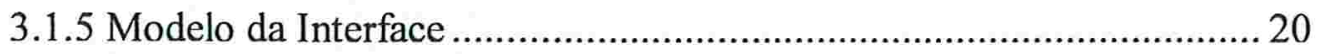

3.2 Variações na Arquitetura Básica de STIs ..................................................... 21

3.2.1 Arquitetura composta pelo Módulo de Controle …….......................... 21

3.2.2 Arquitetura contendo Módulo Multimídia ........................................... 22

3.2.3 Arquitetura para Agentes Tutores.................................................... 24

3.2.4 Considerações sobre a Arquitetura de STIs .......................................26

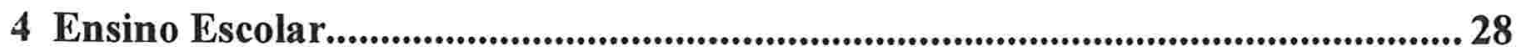

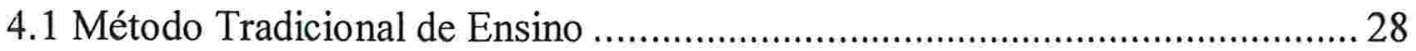




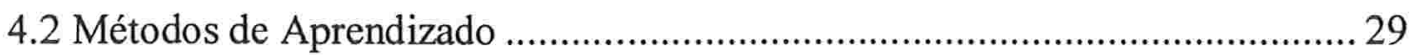

4.2.1 Aprendizado por Diversão ........................................................ 30

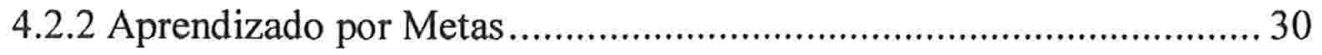

4.2.3 Aprendizado por Experiências ou Baseado em Casos......................... 31

4.2.4 Aprendizado por Simulações (Aprender Fazendo) ........................... 31

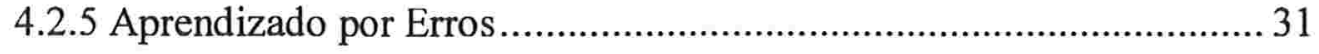

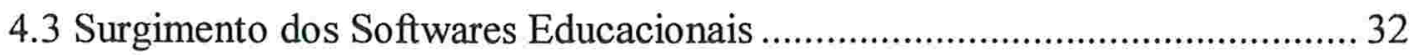

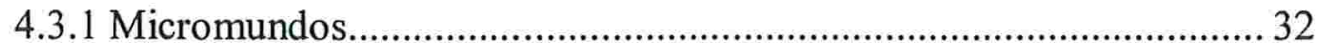

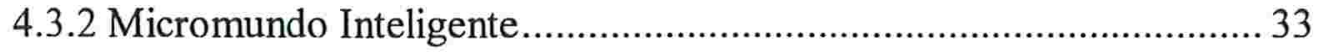

4.4 A Utilização de STIs no Ensino Escolar ......................................................... 33

4.4.1 Exemplos de STIs voltados para ensino acadêmico ......................... 34

5 Treinamento em Empresas............................................................................................ 36

5.1 Métodos Tradicionais de Treinamento ....................................................... 36

$5.2 \mathrm{O}$ Institute for the Learning Sciences (ILS) ................................................. 37

5.2.1 Sistemas Inteligentes baseados em tecnologia do ILS ..................... 38

5.3 Novas Perspectivas para o Treinamento em Empresas................................. 44

5.3.1 Investimentos na área de treinamento.............................................. 45

5.4 Treinamento baseado em STIs ................................................................... 47

5.5 Aplicações de STIs fora do ambiente acadêmico ......................................... 49

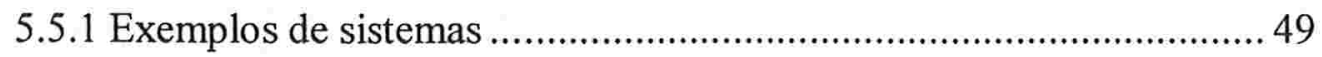

5.6 Aplicações de STIs para treinamento em empresas ...................................... 50

5.6.1 WITS (Welding Intelligent Tutoring System)................................ 50

5.6.2 CALAT: STI para treinamento em Telecomunicações ...................... 51

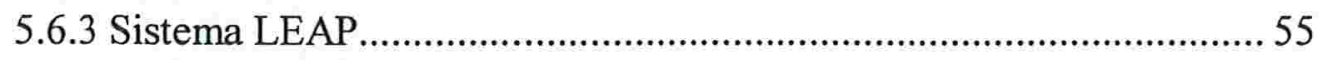

5.6.4 PROTTEL-D Projeto de Sistemas Tutoriais para Telefonia Digital ... 58

6 Metodologias e Ferramentas para Desenvolvimento de STIs .............................. 59

6.1 Limitações de hardware e tecnologia...................................................... 59

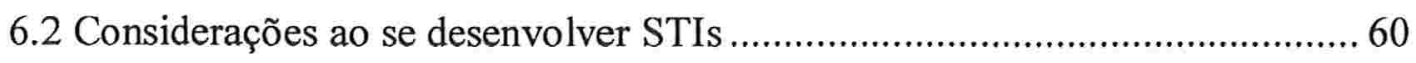

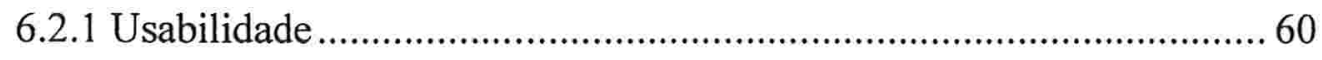

6.2.2 Independência de Domínio........................................................... 61

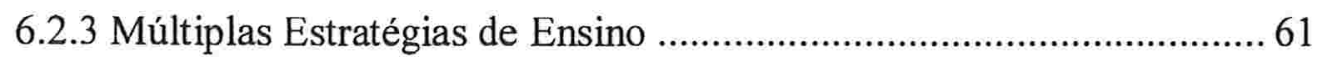

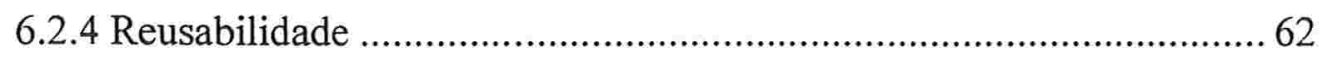




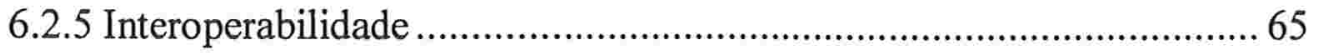

6.3 Metodologias para o Desenvolvimento de STIs......................................... 67

6.3.1 Metodologia de construção a partir do zero ........................................ 67

6.3.2 Metodologias Alternativas para Desenvolvimento de STIs................ 68

6.4 Ferramentas e Shells para Desenvolvimento de STIs.................................... 71

6.4.1 Vantagens da utilização de ferramentas........................................... 73

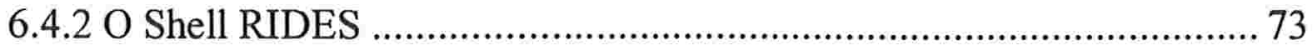

6.4.3 "Intelligent Tutor": Shell, Toolkit \& Technology ............................. 74

6.4.4 Ferramentas com Finalidade Específica......................................... 75

6.4.5 TRAINER: o Sistema Baseado em Casos......................................... 76

6.4.6 Ferramentas Baseados em Hipermídia............................................... 76

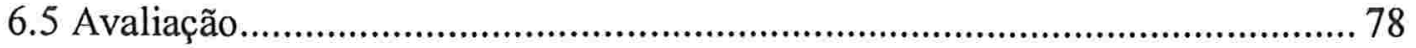

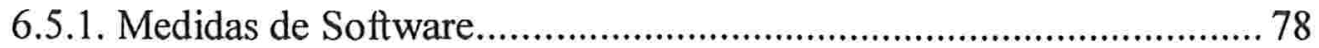

6.5.2 Avaliação de Sistemas Tutores Inteligentes....................................... 78

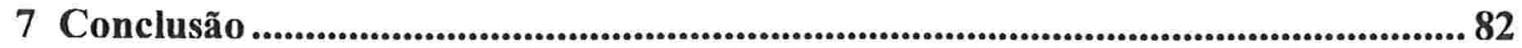

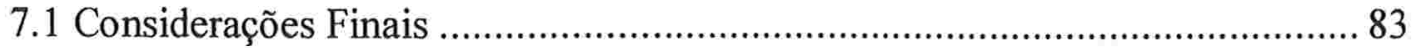

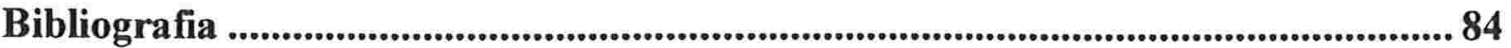




\section{Capítulo 1}

\section{Introdução}

Sistemas Tutores Inteligentes (STIs) são sistemas de aprendizagem baseados em computador, projetados para o ensino de conteúdos através da orientação de pessoas em um domínio específico. Estes sistemas incorporam técnicas para a comunicação/transferência de conhecimentos e habilidades a usuários [ITS96], utilizando modelos avançados na abordagem do domínio e do usuário. Os STIs surgiram dentro da Ciência da Computação a partir da combinação de Instruções Assistidas por Computador (IAC) e da tecnologia de Inteligência Artificial (IA), viabilizando o desenvolvimento de modelos complexos de aprendizado e conhecimento humano. As características chaves que distinguem um STI de outro aprendizado assistido por computador são a habilidade para argumentar sobre o domínio que está sendo ensinado, sobre como o usuário está aprendendo e a capacidade de adaptar o conteúdo e a forma de instrução de acordo com o perfil de cada usuário.

Pesquisas em STIs dentro da Ciência da Computação vêm adquirindo importância cada vez maior nos últimos anos. Os principais motivos pelos quais isto vem ocorrendo devem-se ao fato de que nas últimas três décadas, o conceito de utilizar-se inteligência em máquina vinha mostrando-se promissor para aplicações voltadas a treinamento e educação. Aliado a isso, a disponibilidade de hardware e de recursos de tecnologia a custos mais reduzidos e a disponibilidade de algumas ferramentas que facilitam o desenvolvimento de STIs também têm contribuído para os avanços na área.

A complexidade, o custo, o consumo de tempo, a demanda por enormes recursos computacionais e por ambientes de desenvolvimento razoavelmente grandes exigidos anteriormente, levaram ao estudo e à criação tanto de sistemas modulares que permitem a reusabilidade, quanto de algumas ferramentas que comportam uma variedade de domínios.

Apesar da vasta área de aplicação dos STIs, a grande maioria dos sistemas existentes ainda hoje são voltados para atender ambientes acadêmicos, onde os STIs tiveram o seu início. Mais recentemente, sua utilização principalmente para treinamento em empresas tem apresentado um crescimento considerável. Isto se deve ao fato de que as empresas têm 
passado a reconhecer a importância do aprendizado e do conhecimento como ferramentas competitivas. Ajudar os funcionários a adquirirem habilidades profissionais de maneira rápida e eficiente tem se tornado um objetivo essencial e não mais somente uma meta de treinamento [Sch97].

O objetivo deste trabalho é apresentar uma visão geral da área de STIs, abordando inicialmente a sua origem, o seu histórico e a sua arquitetura básica. Embora as raizes dos STIs estejam no meio acadêmico, buscamos enfocar aqui o treinamento em empresas, que identificamos como sendo uma área em que brevemente haverá uma grande demanda por este tipo de sistema. Por isso, buscamos reunir algumas metodologias e ferramentas, além de alguns aspectos importantes a serem considerados no desenvolvimento de um STI.

Esta dissertação está organizada da seguinte maneira:

No capítulo 2, apresentaremos a origem dos STIs a partir da IAC, da incorporação de técnicas de Inteligência Artificial e da contribuição dos sistemas especialistas. Em seguida, relacionaremos outros grupos de sistemas voltados ao ensino e ao treinamento.

A arquitetura tradicional de um STI está apresentada no capítulo 3, juntamente com a descrição dos quatro modelos que o compõe. A seguir, mostraremos algumas variações na arquitetura básica, a fim de ilustrar a possibilidade de incorporação de outros modelos.

No capítulo 4, apresentaremos o método tradicional de ensino, assim como alguns métodos de aprendizado propostos por Roger Schank. Um estudo sobre metodologias de ensino não faz parte do escopo do nosso trabalho, de maneira que abordamos aqui o ensino de um modo geral. O surgimento dos softwares educacionais e a introdução dos STIs no ensino serão apresentados em seguida.

Iniciaremos o capítulo 5 abordando os métodos tradicionais de treinamento $\mathrm{e}$ apresentando o ILS, um dos pioneiros no desenvolvimento de sistemas para treinamento em empresas. Apresentaremos também alguns STIs voltados para este tipo de aplicação.

Os assuntos principais do capítulo 6 são as metodologias e algumas ferramentas para o desenvolvimento de STIs, e os aspectos importantes a serem considerados ao se desenvolver uma ferramenta ou uma aplicação. Finalizamos o capítulo apresentando algumas medidas para avaliação de STIs.

No capítulo 7, faremos os comentários finais sobre a dissertação. 


\section{Capítulo 2}

\section{Evolução dos Sistemas baseados em IAC aos STIS}

\subsection{Definições básicas}

As definições a seguir são baseadas em [Mcd93].

Um sistema inteligente deve ser capaz de justificar as suas decisões aos seus usuários. Isto envolve explicar como uma solução foi alcançada ou por que uma certa linha de raciocínio está sendo seguida ou não. O tipo de explicação depende do tipo de sistema e do tipo de usuário esperado.

No caso de STIs, é comum encontrarmos referências a dois estilos de explicação: textos enlatados e linguagem natural.

\section{Textos Enlatados}

A técnica de se utilizar textos enlatados, como o próprio nome diz, envolve a utilização de seções de textos enlatados para responder a questões de usuários e para justificar o raciocínio do sistema. Neste caso, o sistema se comporta como um livro texto online, capaz de produzir definições de termos e informações em segundo plano para o problema. A maior dificuldade desta abordagem é a inflexibilidade das respostas, o que faz com que a sua eficiência seja baseada na habilidade do projetista em prever o maior número possível de questões.

A invocação de explicações utilizando este método pode ser baseada em uma sintaxe rígida de uma linguagem de consulta, tal como explique <termo>, ou pode ser baseada na busca de uma palavra chave. Neste caso, o sistema fará a busca por termos ou tópicos com referência na sua base de dados. 


\section{Linguagem Natural}

A compreensão da linguagem natural é um tópico difícil, que tem sido estudado há muitos anos e, embora um sucesso limitado tenha sido obtido, a conversação real com um sistema de software está longe de ser uma realidade. Para entender a linguagem natural gramatical, o software deve ser capaz de analisar frases entradas pelo usuário e ter conhecimento suficiente do domínio para entender o sentido da frase a fim de reagir apropriadamente. Mesmo que o sistema pudesse lidar com frases gramaticais, se a interface fosse realmente natural, ele deveria ser capaz de compreender comandos coloquiais também. Isto causaria futuros problemas.

É possível se proporcionar interação utilizando linguagem natural limitada através da busca por palavras chaves, como sugerido no modelo anterior, oferecendo respostas construídas a partir de seções de texto pré armazenados. Esta solução não é robusta e pode gerar frutrações que acabariam impedindo o seu uso.

\subsection{As origens dos STIs}

Os Sistemas Tutores Inteligentes têm suas origens na Inteligência Artificial, que surgiu entre os anos de 1950 e 1960. Nesta época, pesquisadores como Alan Turing, Marvin Minsky, John McCarthy e Allen Newell imaginavam que computadores que pudessem "pensar" como os seres humanos estavam próximos de surgirem. Muitos achavam que o principal meio para alcançar esta meta era a criação de computadores mais rápidos e maiores. Parecia razoável assumir que, uma vez criadas as máquinas que pudessem pensar, elas poderiam executar qualquer tarefa associada ao pensamento humano, tal como a instrução [Lur96].

As pesquisas em IAC começaram nos anos 50 como meio de proporcionar instruções individuais automatizadas a estudantes, utilizando técnicas e equipamentos que, na época, representavam as crenças sobre como se deveria utilizar o computador como recurso pedagógico. Entretanto, os primeiros sistemas fizeram pouco mais além de reproduzir "textos enlatados" enquanto esperavam uma resposta do aluno [ITS96], pois não tinham meios para oferecer instruções individualizadas, fazendo com que todos os alunos recebessem o mesmo material na mesma seqüência. Como não eram consideradas as informações sobre as habilidades, experiências ou conhecimento prévio dos alunos a respeito do domínio, os sistemas não eram capazes de dar feedback [NTM93].

À medida em que a IAC se desenvolveu, já na década de 60 , surgiram técnicas para decidir qual o conteúdo a ser apresentado ao estudante com base em sua resposta anterior. Assim, os sistemas instrutivos passaram a fazer uso das respostas dos alunos para determinar o material a ser apresentado durante o resto da seção. Desta maneira, não apenas o aluno obtinha feedback, mas também o próprio sistema podia adaptar sua atuação às respostas do aluno. A sofisticação destes sistemas adaptativos era baseada em algoritmos de seleção de tarefas [SB82]. No entanto, isso tornou a criação do material instrutivo um processo mais complexo, levando ao surgimento de linguagens próprias para a especificação desses materiais ("author languages"), que deram origem às atuais ferramentas de autoria para desenvolvimento de 
aplicações educacionais como o Toolbook da Asymetrix, Linkway Live e outros, denominados "authoring systems" ou sistemas de autoria.

Avanços na tecnologia de IAC mais tarde permitiram aos sistemas gerar automaticamente o material de ensino, no todo ou em parte, baseado nas necessidades do usuário, através dos chamados sistemas "generativos" ou adaptativos que surgiram na década de 70 e foram os precursores dos STIs. Essa abordagem foi bastante utilizada em domínios como Aritmética, onde é possível gerar problemas numéricos aleatórios e resolvê-los automaticamente, comparando a solução do sistema com a do estudante. No entanto, mesmo os sistemas generativos não eram capazes de responder a perguntas mais profundas do estudante a respeito de porque ou como a solução era obtida, pois contavam com uma representação superficial do conhecimento [NTM93], e não possuíam uma representação do processo de resolução dos problemas propostos, ou seja, o sistema solucionava os problemas através de algoritmos que nada tinham a ver com a forma como é ensinado às pessoas, não podendo fornecer uma explicação didaticamente útil da solução [Gir97]. Assim, mesmo os programas de computador sofisticados ainda não tinham uma qualificação que se aproximasse à dos instrutores humanos. Os sistemas baseados em IACs não tinham os meios para modelar com precisão o conhecimento de um aluno, ou seja, eles não tinham um modelo dos processos cognitivos do aluno e, portanto, não podiam proporcionar um ambiente de treinamento individualizado robusto.

Tradicionalmente, segundo [Smi98], os sistemas baseados em IAC foram desenvolvidos para proporcionar aos usuários instruções em uma área em particular, sobre a qual eram depois testados. Respostas às perguntas, geralmente de múltipla escolha, eram usadas para direcionar o curso do estudo. A estrutura de um sistema baseado em IAC pode ser representada genericamente como na figura 2.1, porém a estrutura de ramificações nestes sistemas pode ser muito mais complexa do que na representação a seguir.

Neste tipo de sistema, após a apresentação da informação ao usuário, uma série de questões são perguntadas. Se o usuário responder corretamente, a próxima fase da instrução é apresentada. Pode haver uma relação de questões ao final das instruções para avaliar se o desempenho do usuário foi bom.

Se o usuário responder incorretamente às questões, o material instrutivo é apresentado novamente, talvez em um formato ligeiramente diferente. Se após a reapresentação do material o usuário responder errado novamente, então instruções corretivas serão apresentadas. 


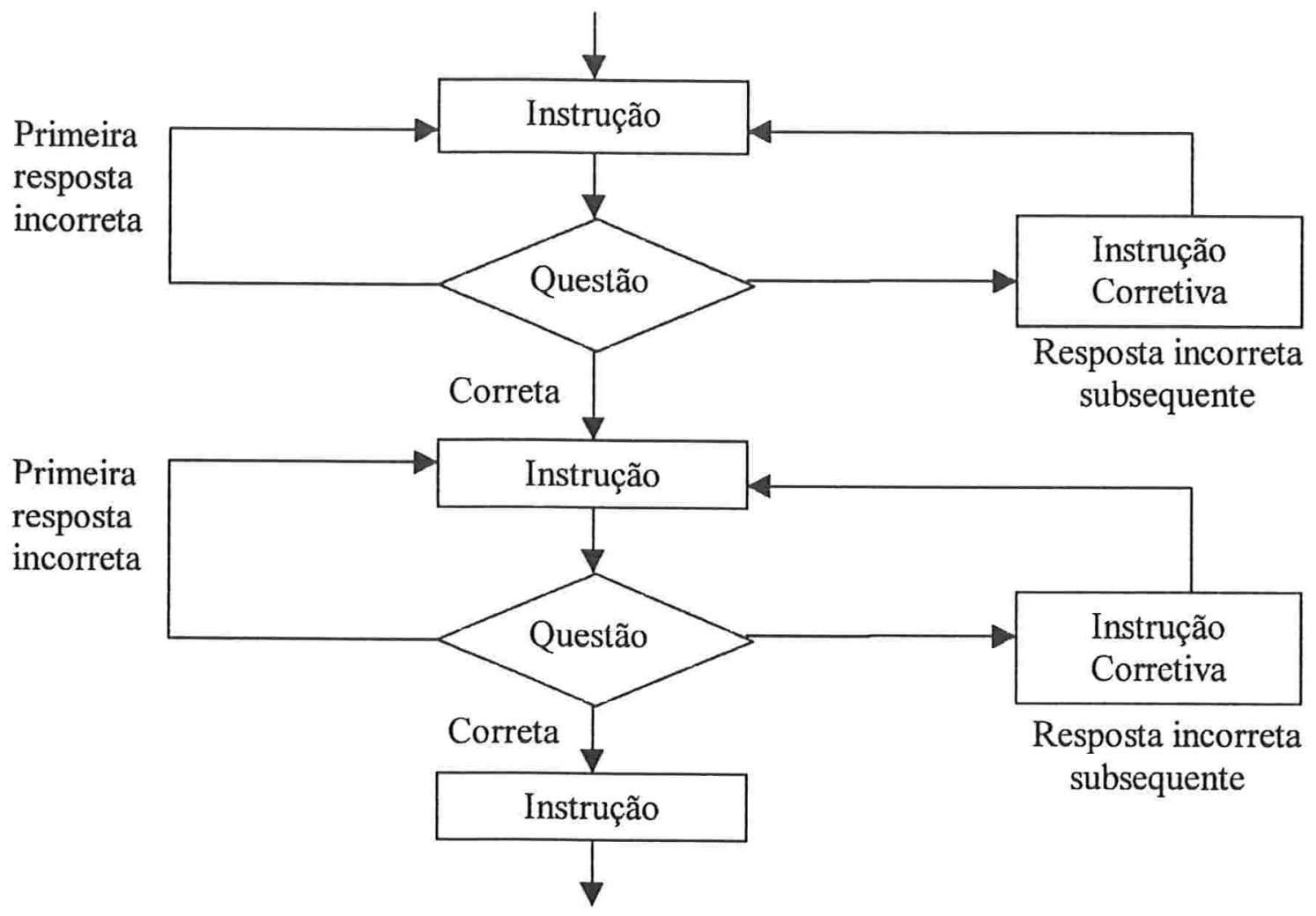

Fig. 2.1 - Roteamento em um sistema baseado em IAC tradicional

\subsection{Surgimento dos Sistemas Tutores Inteligentes}

Os STIs surgiram nos anos 70 para suprir as deficiências da IAC [ITS96]. Seus objetivos originais compreendiam estender o domínio de aplicabilidade, o poder e a precisão dos sistemas adaptativos, de forma a oferecer mais do que simplesmente uma avaliação das respostas dos alunos [SB82]. Segundo [Gir97], podemos identificar três estágios dos STIs. O primeiro estágio compreende o período dos anos 70 até o início dos anos 80 . Neste período, o objetivo principal era explorar métodos e técnicas de IA emergentes aplicadas ao aprendizado e à instrução. A grande contribuição deste período foi a mudança no paradigma de projeto e construção de ambientes educacionais fora da proposta baseada em IAC e a exploração do funcionamento técnico dos STIs.

Ainda nos anos 70, autores como Carbonell e Sleeman [Gir97] observaram que os programas baseados em IAC possuíam uma estrutura de transmissão de conhecimento seqüencial, previamente determinadas, o que impedia os sistemas de se adaptarem ao estilo de cada usuário. Propuseram então um sistema que incorporava técnicas de IA, com a finalidade 
de criar um ambiente adaptativo, que permitisse analisar padrões de erros, analisar o estilo e a capacidade de aprendizado e oferecer instrução especial sobre o conceito em que o usuário estivesse apresentando dificuldade [Gir97]. Surgiram então os IIAC (Instruções Inteligentes Assistidas por Computador ou ICAI - Intelligent Computer Assisted Instruction). Segundo [Gir97], as diferenças mais profundas entre IIAC e IAC tradicionais estão na forma com que se concebe seu projeto. Os IAC conduzem o aluno à resposta correta mediante uma série de estímulos cuidadosamente planejados, ao passo que os IIAC pretendem simular as capacidades cognitivas do aluno e utilizar esses resultados como base para as decisões pedagógicas a serem tomadas.

Embora bons sistemas baseados em IAC tenham sido criados, a vantagem da utilização de uma técnica de modelagem qualitativa característica de IA está na possibilidade de simular o processo de solução de problemas. Desta forma, a utilização de um modelo de solução de problemas por um aluno serve de base para se entender como ele resolve os problemas propostos.

Em 1982, segundo [Lur96], Sleeman e Brown foram os primeiros a criar o termo Sistemas Tutores Inteligentes para descrever esses sistemas que estavam surgindo e diferenciá-los dos sistemas baseados em IAC anteriores.

O segundo estágio dos STIs compreende a segunda metade da década de 80 , período em que as pesquisas se concentraram em verificar as questões envolvendo o aspecto pedagógico, contando com especialistas da área de educação.

Através da utilização dos resultados do trabalho de pesquisa em IA, os STIs se tornaram capazes de empregar estratégias de representação de conhecimento para modelar os processos cognitivos de um aluno. Utilizando modelos precisos do aluno e o conhecimento de um especialista, um STI se tornou capaz de proporcionar instrução no passo e no nível de abstração apropriado ao aluno [ITS96].

O terceiro estágio compreende a década de 90 , onde os pesquisadores estão explorando ambientes e variáveis instrucionais específicas, utilizando equipes interdisciplinares para realizar atividades multidisciplinares. A contribuição deste período deve ser o desenvolvimento de novas teorias e estratégias instrucionais, já que a maioria dos STIs que temos implementados hoje geralmente apresentam uma única estratégia de ensino [Gir97].

\subsection{STIs e Inteligência Artificial}

Sistemas de computador que possuem "inteligência artificial" (IA) devem ser capazes de argumentar, aprender, entender e resolver problemas. $\mathrm{O}$ uso da IA permite dotar o computador da capacidade de processar a linguagem natural, o aprendizado por máquina e a compreensão de discurso. Segundo Linton [Lin95], o objetivo dos pesquisadores de IA, seja em tutores ou em outros domínios, é encontrar uma maneira de fazer o computador realizar algo de forma inteligente. Um dos interesses dos pesquisadores, por exemplo, é descobrir o quê uma pessoa deve saber para poder ensinar, e como colocar a inteligência em um programa. Dessa forma, os pesquisadores de IA em tutores são bem sucedidos se os seus programas tornam o 
computador inteligente de alguma forma tal que ele possa ser útil para o ensino e aprendizado. De acordo com [AR94], "dotar máquinas de capacidades similares àquelas exclusivas dos seres humanos é um dos grandes desafios tecnológicos do momento. A evolução nesta área depende não somente do potencial das máquinas em si mas também de conhecimentos do homem sobre si mesmo". Assim, com o uso da IA, os STIs podem identificar as forças, as fraquezas e o estilo de aprendizado preferido de um aluno. Estes sistemas são capazes de processar informações qualitativamente, reconhecer padrões de comportamento, identificar conceitos errados ou "bugs" na performance e estabelecer um plano de instrução. As instruções podem ser oferecidas sob medida de acordo com o estilo de aprendizado do aluno, e a correção é baseada nos erros do aluno e na percepção dos conceitos errados pelo computador [ITSa96].

De acordo com [RS91], o sucesso em IA depende tanto da quantidade de conhecimento (quanto o programa sabe) quanto da qualidade (quão preciso é o conhecimento e quão acessível ele é).

Os STIs incorporam os conceitos de IA no que se refere ao diagnóstico de falhas [VG96]. O diagnóstico direciona as estratégias de ensino e por isso é um dos principais componentes de um tutor inteligente.

A detecção de falhas é beneficiada pela IA devido, no mínimo, aos seguintes fatores:

- A IA proporciona mecanismos heurísticos de busca que podem reduzir significativamente o tempo de procura.

- Poder na aquisição de conhecimento.

- Os sistemas de IA separam o conhecimento sobre a informação do conhecimento sobre os procedimentos. Um resultado importante desta separação é o fato de que é muito mais fácil manter e modificar o sistema sem erros.

Segundo Linton em [Wu96], a pesquisa em STIs é a pesquisa em IA no domínio dos STIs. O objetivo desta pesquisa é encontrar maneiras para que o computador seja um tutor inteligente, criar uma representação precisa em máquina dos estágios de aprendizado, identificar os estágios intermediários e finais de aprendizado do aluno, e proporcionar orientação das instruções a fim de acelerar o aprendizado.

Técnicas de IA como reconhecimento de padrões, marcas em redes semânticas, "learning" e "planning", entre outros, estão descritos em [Mic82] e podem ser incorporados aos STIs.

De um modo geral, segundo [Eklb], um STI é um sistema de ensino baseado em computador, que foi projetado para ensinar conteúdos e incorpora técnicas de programação que permitem ao tutor exibir um grau de "inteligência artificial". 


\subsection{STIs e Sistemas Especialistas}

Os sistemas especialistas surgiram na década de 70 e foram uma importante descoberta no campo da ciência da computação conhecido como inteligência artificial. Segundo [LDE86] e [For84], sistema especialista é um sistema de IA baseado em uma extensa porção de conhecimento, criado para resolver problemas em um determinado domínio. Este conhecimento é geralmente organizado em um conjunto de regras que permitem ao sistema traçar conclusões a partir dos dados fornecidos ou a partir de premissas (onde premissas representam cada uma das proposições que servem de base à conclusão). Uma definição formal proposta pelo British Computer Society's Specialist Group determina que um sistema especialista "é considerado uma incorporação dentro de um computador de um componente baseado em conhecimento de uma habilidade especialista, de tal maneira que o sistema pode oferecer conselhos inteligentes ou tomar uma decisão inteligente sobre uma função de processamento. Uma característica adicional desejável, que muitos consideram fundamental, é a capacidade do sistema de justificar sua própria linha de raciocínio no momento exigido, de maneira diretamente compreensível ao indagador. O estilo adotado para assegurar essas características é a programação em regras." Os primeiros Sistemas Tutores Inteligentes incorporavam um sistema especialista e um número de sistemas eram construídos baseados em sistemas especialistas preexistentes.

Segundo [Smi98], um sistema especialista freqüentemente tem que lidar com a incerteza e com informações incompletas, e deve ser capaz de explicar decisões e motivos subjacentes como especialistas humanos são capazes de fazer. A figura 2.2 ilustra uma arquitetura simples de um sistema especialista:

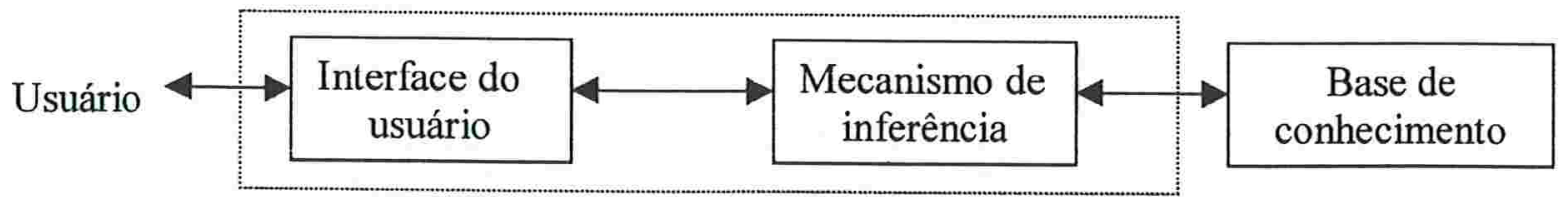

Fig. 2.2 - Arquitetura simples de um sistema especialista

Existem três módulos em um sistema especialista. São eles a interface do usuário que proporciona uma fácil comunicação entre o usuário e o sistema. O segundo módulo é o mecanismo de inferência que é um interpretador para a base de conhecimento. Ele produz resultados e explicações para problemas apresentados a ele ao lidar com a incerteza. O mecanismo de inferência e a interface do usuário são normalmente vistos como sendo um único componente conhecido como shell do sistema especialista. O núcleo do sistema especialista e o último componente na figura é a base de conhecimento que contém o conhecimento para a resolução do problema de uma aplicação específica. Segundo [For84], este conhecimento é composto por fatos (ou declarações) e regras. Fatos são informações de curto período, que podem mudar rapidamente durante o curso de uma consulta. Regras são informações de longo prazo sobre como gerar novos fatos ou hipóteses a partir daquilo que é atualmente conhecido. As regras normalmente são baseadas em regras de produção que têm o formato IF-THEN. Porém, a representação do conhecimento pode ser baseada também em árvores de decisão, redes semânticas e cálculo de predicados. De acordo com a arquitetura 
proposta por [Smi98], a base de conhecimento é isolada do sistema de autoria do sistema especialista para permitir a reutilização do sistema de autoria em outros domínios de aplicação.

De um modo geral, um sistema especialista é um sistema de computador que realiza um conjunto de atividades habilidosas que normalmente seriam realizadas por um especialista humano. O conhecimento de um sistema especialista é normalmente limitado a uma área específica. A intenção do sistema especialista não é substituir um especialista humano, mas sim complementá-lo ou auxiliá-lo.

Sistemas especialistas proporcionam o modelo para codificar, organizar e recuperar/salvar conhecimento sobre o conteúdo de um domínio específico. A estrutura do conhecimento simula o solucionador de problemas "especialista". Sistemas especialistas proporcionam aos STIs a capacidade de argumentação, justificativa, interpretação, prognóstico, diagnóstico, monitoramento, planejamento e controle do comportamento do aluno. STIs modelam o solucionador de problemas "humano" e reconhecem a capacidade humana de utilizar uma variedade de métodos para resolver problemas [ITSa96].

\subsection{Grupos de sistemas voltados a ensino e treinamento}

Segundo [AR94], "o desenvolvimento tecnológico dos últimos anos tem possibilitado o surgimento de importantes instrumentos de apoio à educação. Assim, atividades como ensino e treinamento de pessoas têm contado com um aliado eficiente e moderno: a informática. Esta contribui com três grupos de sistemas":

- Os Sistemas Tutoriais apresentam o conhecimento a ser repassado em forma de texto linear ou não linear podendo ou não conter recursos gráficos. Os usuários deste tipo de sistemas podem percorrer livremente os textos, buscando as informações de seu interesse. Estes sistemas geralmente substituem os manuais nos treinamentos.

- Os Sistemas Tutores destinam-se basicamente ao ensino e diferem-se dos Sistemas Tutoriais em relação aos objetivos propostos e à forma como as informaçōes são transmitidas. Os Sistemas Tutores classificam seus usuários, restringindo e selecionando as informações, mesmo que de forma não inteligente.

- Os Sistemas Tutores Inteligentes, através da utilização de técnicas de IA, possibilitam que a atividade de ensino seja realizada de forma inteligente, levandose em conta as particularidades de cada usuário. Isto é possível graças ao conhecimento manipulado pelo sistema, o qual é devidamente representado e estruturado. Cada usuário - aluno - é avaliado e classificado pelo próprio sistema, que a partir de então decide a linha de evolução do ensino e quais informações poderão ser repassadas. Capaz de justificar suas ações, desenvolver raciocínios e tomar decisões, os STIs em muito se assemelham aos seres humanos na atividade de ensino, e é este o motivo pelo qual vem ocorrendo um grande crescimento nesta área recentemente. 


\section{Capítulo 3}

\section{Arquiteturas de STIs}

\subsection{Arquitetura Básica de um STI}

Como vimos, tanto os STIs como os sistemas baseados em IAC proporcionam material instrucional ao usuário e testam o seu conhecimento, porém suas abordagens diferem consideravelmente. Sistemas baseados em IAC permitem aos especialistas criar interações instrucionais através da representação de suas decisões e problemas na forma de programas. Assim, as instruções são apresentadas de maneira rígida e estruturada, idêntica a todos os usuários. Por outro lado, os STIs propõem uma maneira de capturar o conhecimento de um especialista, que o sistema então utiliza para compôr interações dinâmicas de instruções aos usuários, como um tutor computadorizado, com o poder indutivo similar a um professor humano. Estes sistemas então permitem ao especialista programar o conhecimento utilizado para tomar suas decisões [ITSb96].

Basicamente, os STIs são programas que, interagindo com o usuário, modificam suas bases de conhecimento, percebem as intervenções do usuário e possuem a capacidade de aprender e adaptar as estratégias de ensino ao longo da interação.

Essa interação leva à construção de um modelo cognitivo do usuário, baseado na formulação e na comprovação sobre o seu estilo cognitivo, sobre o seu procedimento, o seu nível de conhecimento sobre o assunto e suas estratégias de aprendizagem. Com base neste acúmulo de informações, o tutor pode então formular uma estratégia de ensino-aprendizagem adequada a atender as necessidades do usuário de acordo com a situação no momento. De uma forma geral, para ser inteligente, um tutor deve ser flexível, isto é, ter capacidade para aprender com o meio ambiente e atualizar seu conhecimento [Gir97].

Para ser eficiente, um STI deve ser capaz de identificar os erros cometidos pelo usuário ao longo da interação e proporcionar os meios para que eles sejam corrigidos. A lógica por trás disso é a de que, para todo erro, existe uma explicação e um raciocínio que leva a ele. Esta 
forma de Instrução Baseada em Computador (IBC) leva a uma transferência de aprendizado da situação contextualizada a situações de base mais ampla. Essa suposição pode então olhar para o erro e determinar o processo de pensamento do usuário que levou ao conceito errado. Uma vez que isso é estabelecido, pode se dar lugar às explicações e instruções apropriadas.

Um STI é um sistema de comunicação de conhecimento. Ele pode ser assim definido, já que a principal ênfase no desenvolvimento destes sistemas é proporcionar o acesso a uma representação do conhecimento que o sistema tentará comunicar ao usuário. Em um STI, a ênfase é dada sobre o conhecimento (o quê) a ser comunicado e não sobre o mecanismo (como) usado para apresentar o conhecimento ao usuário [ITSb96].

Como vimos, um aspecto importante dos STIs é sua habilidade para proporcionar instruções individualizadas de maneira similar ao que pode ser oferecido por um instrutor humano. STIs permitem a emulação de um professor ou instrutor humano no sentido de que os sistemas podem saber o quê ensinar (conteúdo do domínio), como ensinar (estratégias de ensino), e a quem ensinar, através do aprendizado de certas informações de ensino relevantes sobre o aluno ou usuário sendo ensinado. Para atingir este nível de instrução, os STIs utilizam representações sofisticadas do conhecimento de um domínio do especialista (chamado de Modelo do Especialista), o conhecimento didático de um instrutor (chamado de Modelo Tutorial ou Instrucional) e o aluno ou usuário sendo ensinado ou treinado (chamado de Modelo do Aluno). Através da interação destes modelos, os STIs são capazes de fazer julgamentos sobre o que o aluno sabe e como ele está progredindo. As instruções podem então ser fornecidas automaticamente pelo Modelo Tutorial de acordo com as necessidades do aluno, sem a intervenção de um instrutor humano. O STI age como o tutor particular do aluno, enquanto o treinador ou professor humano está livre para focar necessidades mais complexas e individualizadas dos alunos ou usuários.

Segundo [Mur98], o projeto de um STI é baseado em duas suposições fundamentais sobre o ensino.

1. Instruções individuais fornecidas por um tutor competente são muito superiores ao estilo de aprendizado em sala de aula, porque tanto o conteúdo quanto o estilo da instrução podem ser continuamente adaptados de forma a melhor atender as necessidades da situação.

2. Alunos aprendem melhor em situações que se assemelham às situações nas quais eles irão utilizar o seu conhecimento, ou seja, eles "aprendem fazendo". Aprendem através dos seus erros, e aprendem ao construir o conhecimento de uma maneira individualizada.

Um ponto decisivo na geração de um modelo adequado para a situação de ensino é produzir então uma representação realista das habilidades de um instrutor humano. Conforme mostra a figura 3.1, a arquitetura tradicional dos STIs consiste de quatro modelos [GH97], [FPL87], [YC96], [Mur99].

Em seguida, apresentamos a descrição de cada um dos quatro modelos, abordando alguns aspectos positivos e importantes a serem considerados em cada um deles. Embora limitações e deficiências possam ser encontradas, procuramos relacionar as considerações 
relevantes e significativas para a melhor implementação dos modelos ideais para compôr um STI.

- Modelo do Especialista ou Modelo do Domínio

- Modelo do Aluno ou Modelo do Usuário

- Modelo Tutorial ou Instrucional

- Modelo da Interface

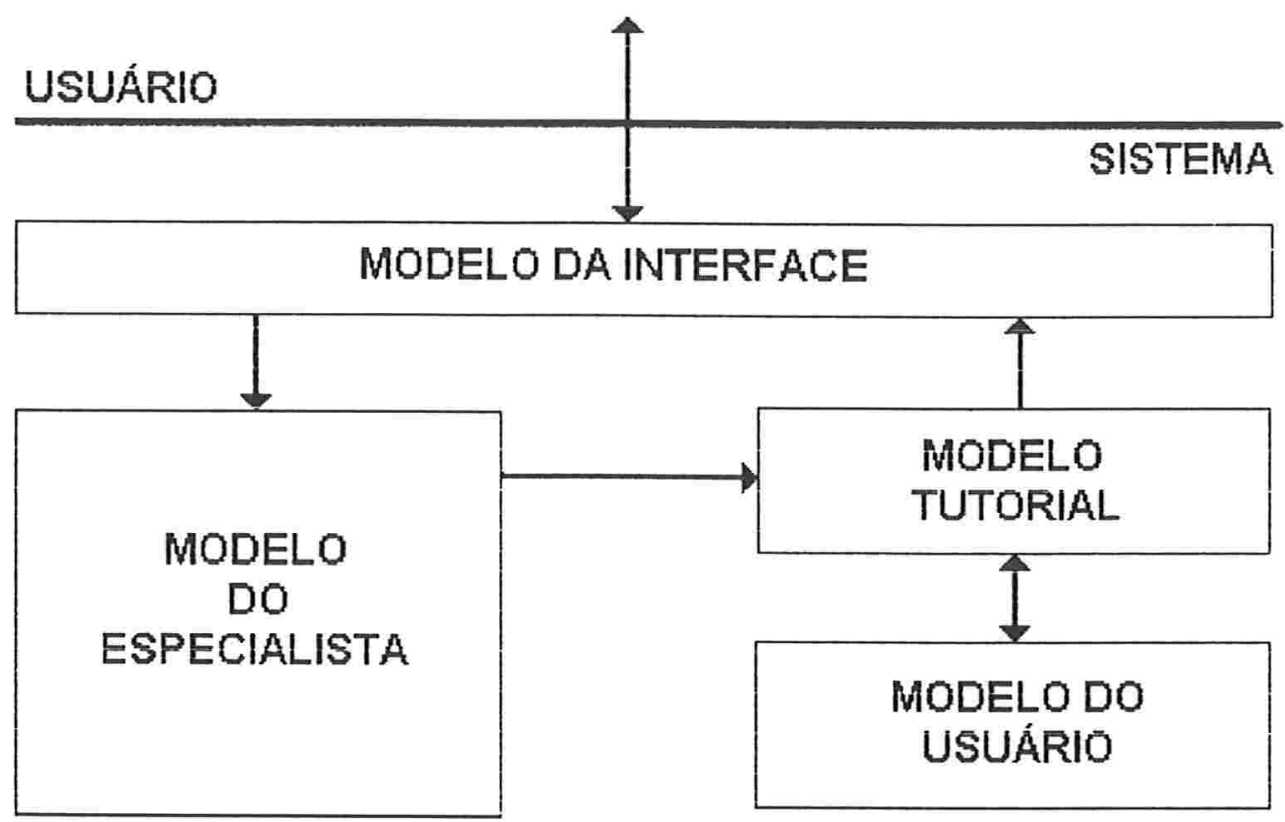

Fig. 3.1 - Representação da arquitetura básica de um STI

\subsubsection{Conceito de Domínio}

Domínio, segundo a definição proposta por [NSB91], refere-se geralmente a uma determinada área ou tema (por exemplo, matemática) ou a um processo dentro da área (por exemplo, utilização de fórmulas matemáticas). Domínio é freqüentemente utilizado como sinônimo de área de aplicação (por exemplo, manutenção de equipamento). Além disso, dentro de uma área de aplicação, o foco geralmente tem sido no nível da tarefa (por exemplo, diagnosticar, localizar e reparar defeitos em um sistema elétrico). Pesquisadores instrucionais, entretanto, tendem a utilizar domínio para fazer referência a resultados de desempenho (por exemplo, o aprendizado de procedimentos). Logo, domínio pode se referir a um assunto, área de aplicação, tarefa ou resultado de desempenho. 


\subsubsection{Modelo do Especialista ou Modelo do Domínio}

O conhecimento do professor ou especialista sobre um domínio está representado neste modelo. Segundo [Gir97], é o componente especialista do tutor, constituído pelo material instrucional, por uma sistemática geração de exemplos, pela formulação de diagnósticos e pelos processos de simulação. Contém o conhecimento sobre o domínio que se deseja ensinar ao usuário.

A base de conhecimentos do domínio é um componente chave do sistema tutor inteligente. Ali está representado o material instrutivo, ou seja, o conteúdo que o tutor deverá ministrar. $O$ fato deste conteúdo ser armazenado em uma base de conhecimento e não em uma base de dados convencional, é um dos fatores que determina a diferença entre um STI e um sistema baseado em IAC convencional [VG96]. De acordo com [Fin91], a partir da perspectiva de IA, o domínio de conhecimento é uma entidade que tem conteúdo e estrutura, assim como procedimentos para utilizar este conteúdo e esta estrutura.

A base de conhecimentos deve proporcionar ao sistema a possibilidade de raciocinar sobre a estrutura do conteúdo a ser ministrado, permitindo-lhe então ser mais do que um simples "virador de página eletrônico" [Gir97]. Esta base de conhecimento deve conter descrições dos vários conceitos e habilidades de um especialista a respeito de um domínio específico, além de um modelo no qual o domínio possa ser interpretado e portanto, proporcionar uma forma dinâmica de conhecimento. O conhecimento codificado para lições iniciais pode ser reutilizado quando for apropriado para futuras lições, desde que o usuário tenha intenção de utilizar algum conhecimento adquirido anteriormente, juntamente com novos conhecimentos, a fim de abordar tarefas mais complexas [LC92].

Porém, a informação correta por si só não é suficiente. O conhecimento sobre erros típicos e mal-entendidos dos alunos também é necessário para avaliar o grau de conceito errado e para ser capaz de mostrar ao aluno uma maneira de melhorar sua compreensão.

Segundo [FPL87], as técnicas de inteligência artificial utilizadas para a sua construção são as de representação de conhecimento e organização de bases de conhecimentos.

No modelo do domínio, abordagens sobre a funcionalidade e os aspectos de comunicabilidade [ITSb96] devem ser considerados.

\section{Funcionalidade}

1. Proporcionar uma fonte para o conhecimento a ser apresentado, incluindo:

- explicações de conceitos e respostas a alunos;

- tarefas e perguntas de alunos.

2. Servir como um padrão para a avaliação do aluno, através de:

- geração de soluções assim como todos os passos intermediários para um dado problema; 
- geração de caminhos de soluções perceptíveis para guiar na resolução de problemas;

- habilidade para gerar caminhos de múltiplas possibilidades de soluções para fins de desempenho.

\section{Aspectos de Comunicabilidade}

1. Suportar explicações de suas ações e conclusões alcançadas.

2. Permitir acesso aos seus passos de raciocínio para permitir inspeção e interpretação.

3. Proporcionar um grau de similaridade com os métodos de raciocínio utilizados pelos especialistas humanos.

4. Devido à natureza do modelo, o modelo do especialista incorpora uma visão específica do domínio.

\subsubsection{Modelo do Aluno ou Usuário}

Enquanto o modelo do especialista captura o conhecimento que um especialista utiliza na resolução de problemas, o modelo do aluno contém medidas do conhecimento do aluno sobre a área do problema. Sua principal função é capturar a compreensão ou incompreensão do aluno sobre o conhecimento do domínio e avaliar suas aptidões. Estas tarefas são executadas mediante forte interação com o modelo do especialista [FPL87].

O modelo do aluno é considerado a parte mais importante de um STI, já que o aluno tem o papel principal no processo de ensino. De maneira geral, este modelo pode ser visto como contendo um perfil avançado do aluno. A exatidão e os detalhes deste perfil são determinados pela "bandwidth" (largura de banda) do modelo do aluno (ou seja, a qualidade e quantidade das entradas no modelo). A "bandwidth" determina a granularidade na qual as ações do aluno podem ser rastreadas. Granularidade fina proporciona mais informação ao modelo do aluno para inferir detalhes sobre a compreensão do aluno a respeito do domínio do problema.

Uma função deste modelo é permitir que o STI se adapte a cada aluno, individualizando o ensino. A chave para a individualização em um sistema tutor é o conhecimento sobre seus usuários, que está contido no modelo [NTM93]. O modelo tenta formular uma representação do estado atual do conhecimento e do desempenho do aluno no assunto que está sendo ensinado. A estrutura do modelo pode ser derivada a partir do comportamento do aluno na resolução do problema, das perguntas diretas feitas pelo aluno, dos dados históricos (baseados em suposições da avaliação do nível de habilidade do aluno, principiante ao especialista), e do nível de dificuldade do conteúdo do domínio [ITSa96]. Evidentemente, este modelo deve ser dinâmico, pois a própria interação já leva o aluno a alterar seu estado cognitivo ao longo do tempo.

Com a finalidade de entender a maneira como um aluno aprende [NTM93], o sistema deve saber quais os conceitos que ele sabe, que estratégias ele adota e quais as deficiências que 
ele tem. Além disso, o sistema deve tentar saber como o aluno atingiu o status atual sobre o domínio em questão.

Os STIs comparam a performance real do aluno ao modelo para determinar se foi assimilado o conteúdo do domínio [ITSa96]. O modelo do aluno é utilizado pelo modelo tutorial para aplicação de uma estratégia pedagógica adequada [FPL87]. Avanços pelo currículo dependem da avaliação do STI sobre o nível de proficiência do aluno. O modelo do aluno contém uma base de dados de conceitos errados e conceitos insuficientes. Esta base de dados é conhecida como "biblioteca de bug" [ITSa96], que pode fazer parte do modelo do domínio, dependendo da implementação. O modelo do aluno armazena também informações a respeito da extensão do conhecimento do aluno em relação ao domínio e suas características de trabalho (tipo de aprendiz e suas preferências). Estas informações proporcionam os fundamentos para as decisões que o modelo tutorial deve fazer durante o processo de aprendizado e ensino.

$\mathrm{O}$ tutor inteligente ideal deve resolver problemas de maneira semelhante ao humano. $\mathrm{O}$ tutor prognostica a performance do aluno. Se a performance não combinar com o prognóstico, o sistema deve determinar se a deficiência é devido a um conceito errado ou insuficiente. Uma vez que o tutor reconhece o conceito errado ou insuficiente, ele faz um diagnóstico e prescreve uma correção instrucional [ITSa96].

De uma forma geral, o modelo tenta representar todos os aspectos do comportamento e do conhecimento do aluno que tem repercussão em relação à sua performance e aprendizado. Esta não é uma tarefa simples, considerando-se a diferença entre computador e humanos, assim como as limitações em banda do canal de comunicação [ITSb96].

Técnicas de IA como reconhecimento de padrões [Mic82] (aplicado ao conjunto de respostas do aluno) e marcas numa rede semântica ou numa base de regras (indicando as áreas em que o aluno apresenta aptidões e deficiências) vêm sendo utilizadas para modelar o aluno ou usuário [FPL87]. As redes semânticas, de acordo com [LDE86], são representações gráficas do conhecimento. Elas são constituídas por nós que são representados por círculos e arcos que são representados por linhas com setas. Os nós possuem nomes e contêm informações, ao passo que os arcos conectam os círculos, mostrando a relação entre eles. De um modo geral, as redes semânticas descrevem a relação entre as coisas que são representadas pelos nós e podem ser usadas para gerar estruturas e objetos. Uma rede semântica pode ser usada para gerar regras para um banco de conhecimentos.

Segundo [Gir97], existem outras técnicas muito utilizadas na construção do modelo do aluno, como por exemplo:

- comparar a conduta do aluno com a de um especialista e verificar os pontos em comum;

- considerar as preferências do aluno e seus objetivos particulares;

- identificar as coisas que ele sempre costuma esquecer quando interage com o tutor. 
Neste modelo, é importante considerar a informação contida no modelo, a representação do aluno e o processo de diagnóstico [ITSb96].

\section{Informação}

1. Através da capacidade de inferência, o sistema poderia produzir uma interpretação das ações do aluno e, a partir disso, reconstruir o conhecimento que levou a essas ações.

2. Gerar um modelo do conhecimento do aluno a partir da representação do sistema em relação ao objetivo do especialista. Isto permite uma comparação entre o estado do conhecimento do aluno e o conhecimento de um especialista com a finalidade de avaliar e ajustar técnicas instrutivas.

3. O modelo pode determinar interpretações incorretas do objetivo do conhecimento a partir destas representações explícitas para que ações remediáveis possam ser tomadas.

4. A informação detalhada contida no modelo do aluno pode permitir a geração de informação explicativa sobre a origem dessas porções de conhecimento incorretas.

\section{Representação do Aluno}

1. O modelo tenta definir tanto o conhecimento correto quanto o incorreto a partir de primitivas de uma linguagem para o domínio. O objetivo é modelar todos os conceitos errados e interpretações corretas que um aluno pode ter a partir de combinações apropriadas dessas primitivas.

2. Uma alternativa para esta abordagem é coletar uma grande quantidade de informação sobre erros e conceitos errados sobre um determinado domínio e um determinado grupo (amostra) de estudantes e incorporá-los como primitivas da linguagem de modelamento.

3. O modelo do aluno deve permitir que possam ser feitas previsões sobre um determinado aluno em um contexto particular.

\section{Processo de Diagnóstico}

1. Pode ser dirigido pelo modelo, ou seja, levar o modelo a explicar os dados sobre o aluno, ou dirigido pelos dados, ou seja, construir um modelo a partir dos dados do aluno.

2. A interpretação das ações de um aluno podem proceder tanto de maneira top-down, ou seja, quando existem poucas maneiras de implementar um determinado objetivo, ou de maneira bottom-up, ou seja, quando passos individuais têm somente algumas interpretações possíveis. 
3. A habilidade de lidar com a presença de ruído no modelo de dados do estudante afeta diretamente a precisão e relevância do próprio processo de diagnóstico.

4. O resultado de um diagnóstico pode ter a forma de passos ativos tomados pelo sistema durante a sessão de ensino, assim como a forma de observações passivas.

5. O diagnóstico inferencial (excluindo entradas dos alunos) e interativo (diálogo entre aluno e STI) pode ser utilizado para sustentar diagnósticos de esforço de aprendizado do aluno.

\subsubsection{Modelo Tutorial ou Instrucional}

O conhecimento didático de um instrutor humano está representado neste modelo. Este componente do STI deve conter estratégias fundamentais para ensinar o conteúdo de uma lição, ou seja, a maneira de apresentar e escolher exemplos convenientes ou o momento apropriado para fornecer ajuda, através da aplicação de uma estratégia pedagógica de ensino. Segundo [Gir97], "as estratégias constituem conhecimento sobre como ensinar, ou seja, sobre como gerar, a partir das informações de diagnóstico, monitoração e análise, uma seqüência de táticas de ensino capazes de apresentar com sucesso um determinado tópico a um determinado aluno." A maioria dos autores concorda que uma estratégia de ensino deve definir:

- Quando interromper? Que razões justificam interromper o curso de raciocínio ou aprendizagem do aluno?

- O que dizer?

- Esta questão se desdobra em:

- seleção do(s) tópico(s) apresentado(s);

- ordenação dos tópicos, se houver mais de um.

- Como dizer?

- Esta é provavelmente a questão mais difícil. Não há soluções gerais concretas, e muitos autores apontam aqui a falta de teorias pedagógicas suficientemente detalhadas.

De acordo com [Gir97], existem basicamente três métodos de ensino muito utilizados pelos modelos tutoriais: o método socrático, o método supervisionado (modelo coaching) e o método de hipertexto. No método socrático, partindo de conhecimentos que o aluno já domina, o tutor ensina através de perguntas e diálogos, levando o aluno a tirar suas próprias conclusões. Este é o seu grande ganho em relação aos sistemas baseados em CAI tradicionais, onde as conclusões são apresentadas ao aluno e ele as recebe de forma passiva, mesmo que as mesmas sejam apresentadas em sofisticados recursos multimídia. 
Por outro lado o modelo coaching (supervisionado), "emprega atividades de entretenimento como jogos para transmitir conceitos relacionados. A aprendizagem é uma conseqüência indireta da atuação nessa simulação" [Gir97].

O terceiro modelo permite que o aluno navegue em uma estrutura de hipertexto de modo a trabalhar de uma forma mais participativa e explorando o conteúdo a partir dos seus interesses. Desta forma, o aluno pode controlar dinamicamente as informações e refletir sobre a sua lógica pessoal que na maioria das vezes, é diferente da lógica do autor do sistema. Este modelo permite ao STI conter diferentes formas de representação do conhecimento em um mesmo documento, organizado de maneira que cada subdivisão lógica do assunto esteja ligada ao documento através de diversos tipos de ligações, possibilitando que o aluno navegue por diferentes alternativas para explorar o domínio.

De acordo com [ITSa96], o STI interage ativamente com as entradas do usuário e diagnostica o nível de compreensão ou incompreensão do usuário a respeito do domínio do conhecimento. O tutorial exerce certo controle sobre a seleção e a seqüenciação de informações ao responder perguntas dos usuários a respeito do assunto e ao determinar quando o usuário precisa de ajuda e que tipo de ajuda é necessária. Um STI eficiente deve atender às constantes mudanças de necessidades do usuário, diagnosticando as suas fraquezas características e adaptando as instruções de acordo, ao extrair as medidas de desempenho do perfil armazenado no modelo do aluno.

Neste modelo, é importante se levar em consideração o processo didático e os graus de controle sobre o processo de aprendizado [ITSb96].

\section{Processo Didático}

1. Interações de regras especializadas ou princípios genéricos podem ser utilizados para tomar decisões pedagógicas (didáticas) em relação à estratégia de ensino aplicada a um aluno em particular.

2. A nível global, estas decisões didáticas estabelecem a seqüência de episódios de instruções.

3. A nível local, estas decisões didáticas determinam quando e onde as intervenções devem ocorrer.

4. Intervenções podem ter a forma de orientação na execução de atividades do aluno, explicação de processos e fenômenos, e esforços de correção.

\section{Graus de Controle}

O sistema pode ser configurado para proporcionar vários graus de controle sobre o processo de aprendizado. Ele pode:

- monitorar de perto a atividade do aluno e adaptar as respostas do sistema às ações do aluno mas nunca dar o controle ao próprio aluno sobre a atividade de aprendizado 
- compartilhar o controle entre o aluno e o sistema à medida em que eles trocam perguntas e respostas (diálogos de iniciativa mista) - utilizar aprendizado por descoberta guiada ou atividades monitoradas para proporcionar ao aluno controle total sobre a atividade de aprendizado.

\subsubsection{Modelo da Interface}

Um STI deve apresentar seu conteúdo de maneira compreensível. O uso de representações gráficas, principalmente em animações, pode proporcionar ilustrações, talvez ainda de um modo melhor que em instruções convencionais. Este modelo é responsável por selecionar a forma apropriada de comunicação entre o STI e o usuário, permitindo a troca de informações a fim de obter melhores resultados no processo de ensino-aprendizagem. O progresso no projeto de interfaces aumenta a possibilidade de se obter um diagnóstico melhor. Embora ele opere em conjunto com o modelo do aluno e o modelo tutorial, é importante que a interface seja descrita separadamente devido a sua importância como mecanismo de comunicação [ITSb96]. Segundo [Gir97], esta importância vem do fato de que é na interação que o sistema tutor exerce duas de suas principais funções: apresentação do material instrucional e monitoração do progresso do aluno ou usuário através da recepção da sua resposta.

Primeiramente, finalizando a forma na qual a informação é apresentada, a interface afeta a compreensão na parte do aluno. Segundo, avanços na tecnologia de mídia têm proporcionado maneiras de enriquecer a largura da banda de comunicação entre o sistema e o aluno [ITSb96].

O modelo da interface é a única parte do STI que os usuários realmente vêem. Como resultado, todos os outros modelos no sistema tutor (especialista, tutorial e aluno) devem descrever sua funcionalidade e suas representações em termos do que o usuário vê. Para manter a atenção e o interesse do usuário, as interfaces devem ser fáceis de se usar e atraentes aos olhos. A falta de atenção nessas áreas poderá causar o cansaço e assim, limitar a eficiência do processo de aprendizado. Em um sentido bastante real, o modelo da interface dirige a compreensão do usuário pelo resto do sistema [Swi91].

É importante se considerar a funcionalidade e as expectativas em relação ao modelo da interface [ITSb96].

\section{Funcionalidade}

1. Processamento de linguagem natural proporciona a possibilidade do aluno e o sistema se comunicarem de maneira mais natural (para o aluno). Isto melhora o nível de comunicação, a medida em que introduz um estilo "em tom de conversa" à interação. A interface em linguagem natural utiliza um subsistema composto por um dicionário de palavras e um conjunto de regras gramaticais, podendo possuir a capacidade de aprender novas regras, novas construções sintáticas e categorias gramaticais, corrigir erros ortográficos através da geração e comprovação das hipóteses. A forma do aluno se comunicar com o tutor é feita através de restrições na linguagem a fim de viabilizar a comunicação. 
2. A apresentação de informação em forma de texto tem sido substituída, em muitos casos, pelo uso de representações gráficas. O projeto de apresentações gráficas requer esforço considerável devido à quantidade de detalhes exigidos, assim como a sensibilidade a fatores humanos que devem ser abordados.

\section{Expectativas}

1. Clareza na apresentação é fundamental para o processo de aprendizado. Qualquer interpretação errada da informação apresentada devido ao estilo de apresentação ambígua, pode induzir o aluno a um erro, levá-lo à conclusão errada ou confundi-lo totalmente.

2. Para manter a atenção e o compromisso do aluno, as interfaces devem ser fáceis de utilizar e dirigir a eficiência do processo de aprendizado, além de possuir uma riqueza de recursos na apresentação do material instrucional.

3. Deve ser óbvio ao aluno quais apresentações, interações e capacidades de controle são proporcionadas pela interface, de maneira a prevenir confusão e ações não realizadas.

4. É desejável que haja facilidade para troca de iniciativa de diálogo: o aluno deve poder intervir facilmente no discurso do tutor, e vice-versa.

5. O tempo de resposta deve permanecer dentro de limites aceitáveis.

\subsection{Variações na Arquiitetura Básica de STIs}

As arquiteturas de STIs podem variar de acordo com a implementação. Nesta seção, vamos relacionar algumas dessas variações.

\subsubsection{Arquitetura composta pelo Módulo de Controle}

Em [Gir97] e [VG96], é proposta uma arquitetura tradicional de STIs composta por:

- Interface

- Estratégias de Ensino (Modelo Tutorial)

- Modelo do Aluno

- Base de Conhecimento do Domínio (Modelo do domínio / especialista)

- Módulo de Controle 


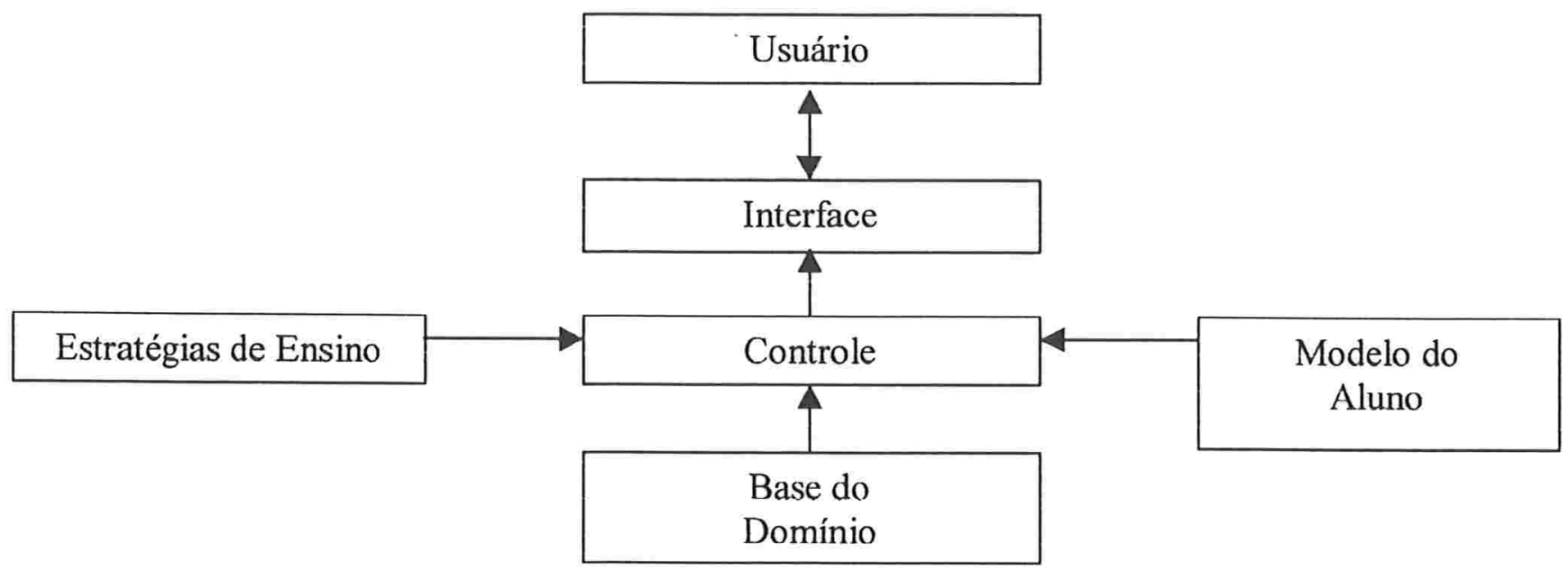

Fig. 3.2 - Arquitetura tradicional de um STI

Nesta arquitetura representada pela figura 3.2, além dos quatro modelos já conhecidos e descritos na seção anterior, identificamos o Módulo de Controle, que é responsável pela coordenação geral do tutor, no que diz respeito às suas funções, interfaces de linguagem natural, troca de informações entre os modelos e comunicação com outros programas utilitários através do sistema operacional.

A comunicação entre os módulos do tutor consiste em armazenar ou ler arquivos, manter um arquivo histórico da sessão de aprendizagem e a ativação e desativação dos bancos de dados, que podem ser imaginados como "mundos" criados a partir da interação entre o tutor e o aluno.

Os STIs possuem uma capacidade de aprendizagem no que se refere às alterações feitas na regra do tutor, resultantes do processo de interação com o usuário.

Em alguns tutores, o núcleo inicial permanece inalterado ao final da sessão, reiniciando de maneira idêntica para qualquer novo usuário, ao passo que em outros modelos mais aperfeiçoados, o banco de dados inicial é alterado a cada interação. Deste modo, o sistema evolui, aprendendo com cada usuário.

\subsubsection{Arquitetura contendo Módulo Multimídia}

Atualmente, a crescente demanda pelo desenvolvimento de STIs tem levado à utilização de soluções interativas de multimídia. $\mathrm{O}$ acesso a gráficos de alta tecnologia, animação e capacidades de vídeo e som, além da proliferação de softwares de geração de multimídia, têm possibilitado produzir apresentações impressionantes e módulos interativos com mais facilidade. 
Entretanto, enquanto sistemas de multimídia típicos voltados para educação permitem aos usuários navegarem através de material relacionado a algum assunto, de maneira atrativa e informativa, sabe-se bem que virar páginas e navegar não garantem o aprendizado. Apresentações de gráficos e simulações não são suficientes, pois a experiência deve ser autêntica e significativa para o usuário. Uma maneira de superar esta falha é através da utilização dos sólidos fundamentos de STIs como plataforma para um controle mais sofisticado de objetos de multimídia em um ambiente de aprendizado. Neste tipo de sistema, o tutor pode ajudar a guiar o aluno através do processo de raciocínio através de interações inteligentes, proporcionando conselhos ou redirecionando o foco de atenção do aluno nos momentos apropriados, e empregando seus recursos multimídia da maneira mais útil ao aluno no momento. Um bom exemplo deste tipo de sistema é o CALAT, descrito em detalhes na seção 5.6.2, e cuja arquitetura está representada pela figura 5.1.

A arquitetura representada pela figura 3.3 foi proposta em [Rog95], e está sendo utilizada para a implementação de módulos tutores inteligentes para complementar os cursos técnicos de treinamento interno para o Boeng Defense and Space Group.

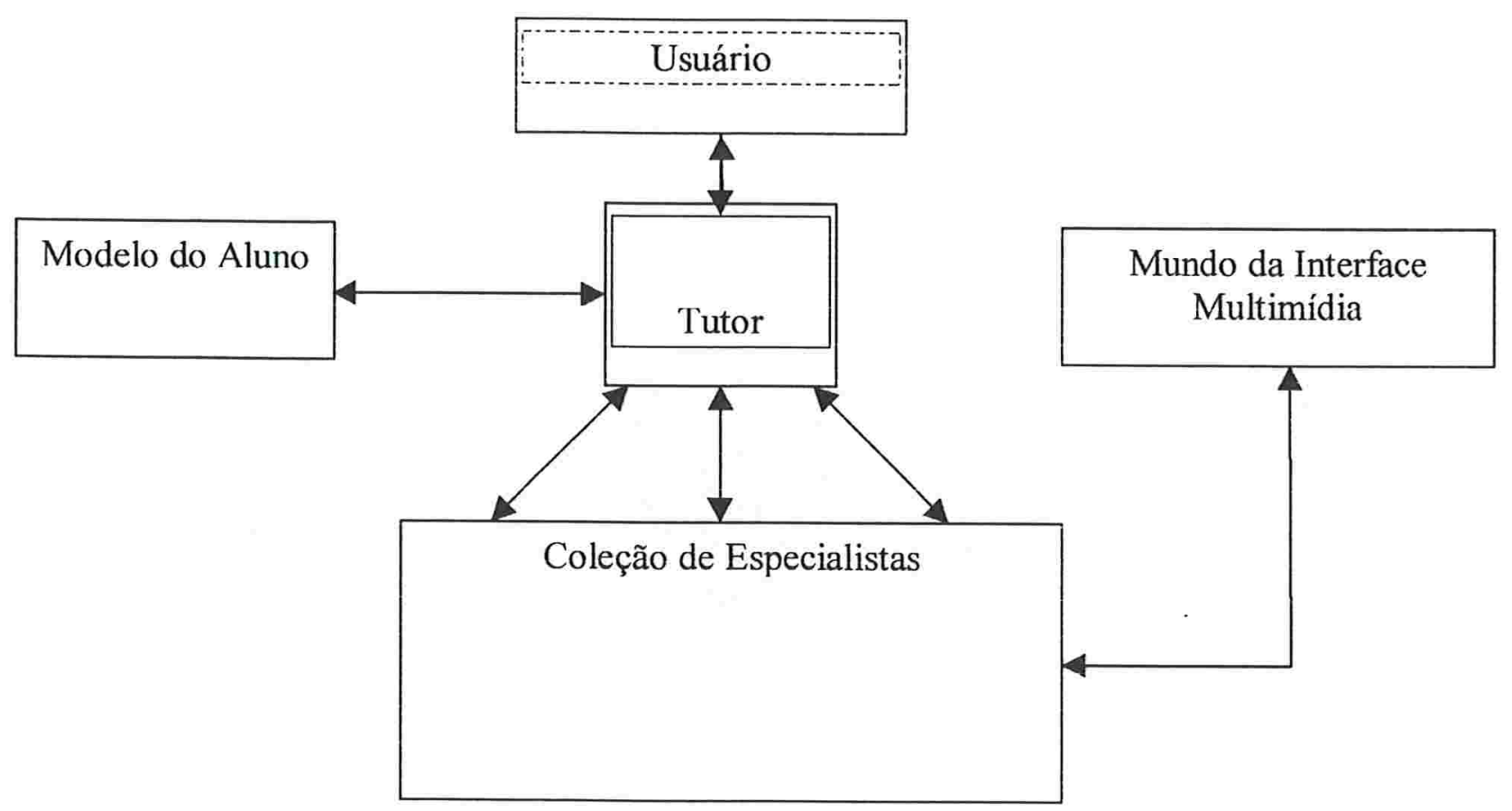

Fig.3.3 - Arquitetura de STI com módulo de multimídia 
Nesta estrutura, o modelo do aluno rastreia o desempenho do aluno e mantém um perfil do seu nível e de suas habilidades naquele nível. Isto inclui informações sobre a última lição aprendida, controle do progresso através de avaliações de testes, e uma indicação do nível de experiência do aluno (novato ou especialista). O domínio de conhecimento está codificado no componente especialista. No modelo, este conhecimento está encapsulado como uma "coleção de especialistas", onde cada um tem um pouco de conhecimento sobre uma pequena parte do domínio, e é capaz de exibí-lo em diferentes modos de apresentação, de acordo com a estratégia de ensino sendo aplicada. O particionamento do conhecimento do domínio em segmentos pequenos proporciona flexibilidade na construção de planos de lições (i.e., se uma pequena revisão de um determinado tópico é desejada, utilizando um determinado modo de apresentação, aquele especialista pode ser invocado sem necessidade de apresentar material adicional). O módulo tutor controla toda a sessão de treinamento, examina o perfil do aluno, escolhe os tópicos e cria o planejamento apropriado da lição. Este planejamento de lições consiste de uma série de objetivos que são atingidos através dos serviços dos especialistas correspondentes.

Além destes três componentes, este modelo também inclui um mundo de interface multimídia, que contém os objetos de multimídia individuais (filmes, sons, simulações, etc.) que são utilizados pelos especialistas do domínio, e também circundam os objetos e relacionamentos do metafórico "mundo" dentro do qual a sessão tutorial é conduzida. Esta é uma extensão da noção de micromundo, que é comum em IA.

O modelo descrito acima corresponde à primeira versão do sistema, em que o tutor tem o controle total, devendo traçar o plano, buscar os especialistas apropriados e invocá-los. A desvantagem desta versão está na impossibilidade do sistema em realizar uma busca exaustiva por especialistas apropriados a todo momento, de maneira que a solução mais eficiente nem sempre será encontrada. Na tentativa de minimizar este problema, uma tentativa de evolução deste modelo foi proposta em [Rog95].

\subsubsection{Arquitetura para Agentes Tutores}

Ritter e Koedinger [RK96] desenvolveram um ambiente de aprendizado que incorpora elementos tutores em pacotes de softwares preexistentes, com um conjunto de padrões para agentes tutores que interagem com ferramentas complexas.

Estes sistemas compartilham algumas características básicas na arquitetura, que definem o tipo de ambiente de aprendizado sendo criado. Este ambiente de aprendizado, por sua vez, deve conhecer os objetivos do usuário ao executar uma determinada ação. Este modelo de sistema tutor apresenta um problema ao usuário, porém não exige que ele seja resolvido de uma maneira particular, e sim, que seja realizado dentro do próprio ambiente.

$\mathrm{O}$ ambiente de aprendizado completo descrito aqui contém quatro componentes básicos: uma Ferramenta, um Agente Tutor, um Tradutor e um Gerenciador de Currículo. A figura 3.4 representa a arquitetura deste sistema. O Gerenciador de Currículo seleciona problemas para o usuário, porém é opcional. Sem ele, o agente tutor pode proporcionar suporte a alunos com 
problemas na escolha, mas não pode proporcionar conselhos sobre o próximo problema mais apropriado.

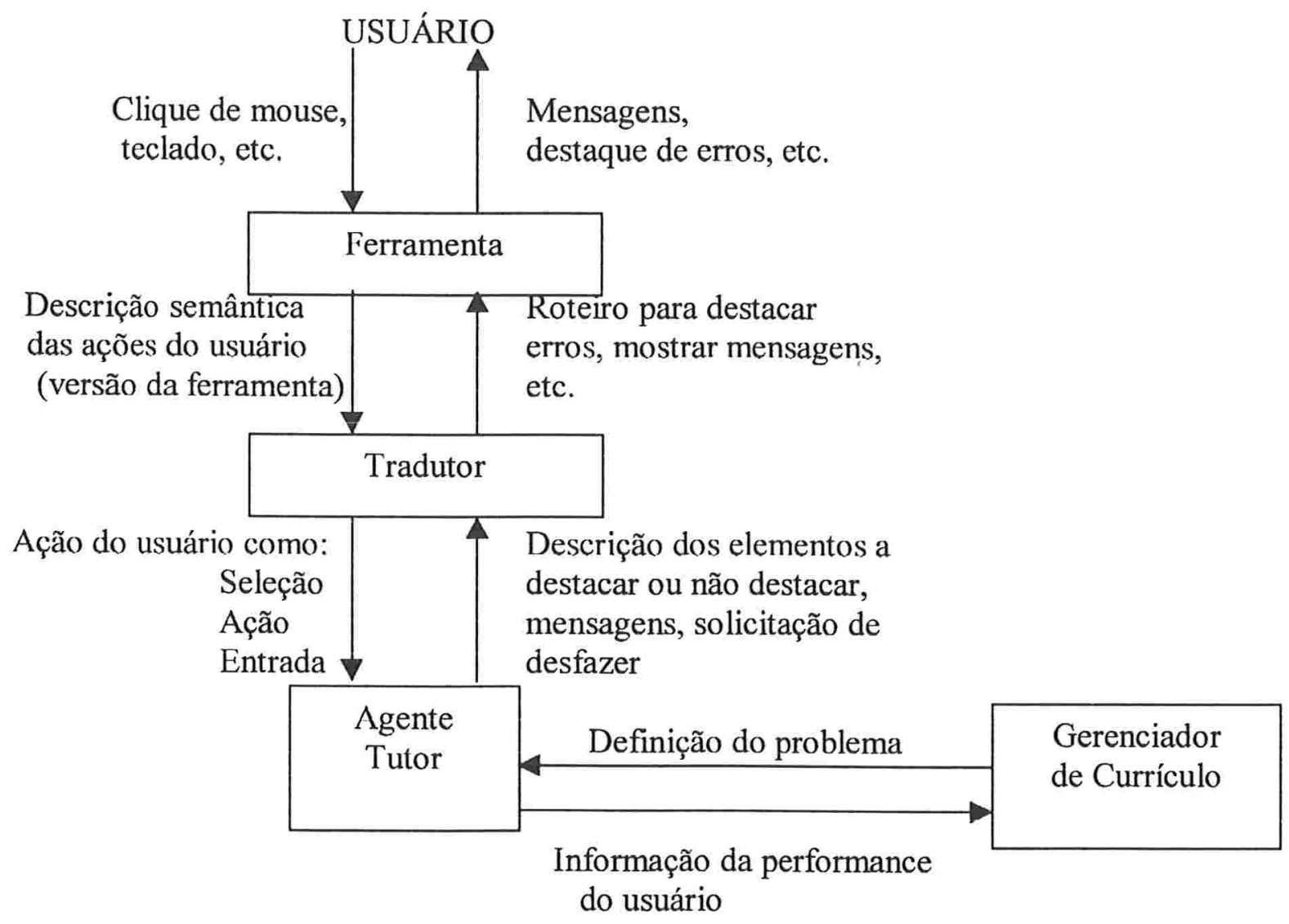

Fig. 3.4 - Arquitetura Genérica de Agentes Tutores

\section{Ferramentas}

Uma ferramenta é um hardware ou software que pode ser utilizado para realizar algum trabalho em um domínio particular. A criação de uma ferramenta envolve tipicamente um equilíbrio entre generalidade e facilidade de uso.

Para se monitorar as ações do usuário, é importante que a ferramenta comunique estas ações em um nível apropriado de detalhe. Já que as ações do usuário serão monitoradas em relação a um objetivo de alto nível, é necessário entender a semântica das ações do usuário, ao invés dos detalhes da manipulação da interface. É importante também receber informação em detalhes suficientes para proporcionar o feedback apropriado. De uma forma geral, é necessário entender as ações do usuário em termos do trabalho realizado, e não das ações de interface executadas. 


\section{Agentes Tutores}

Agentes tutores são partes de software que monitoram ações do usuário. A finalidade da monitoração pode ser para determinar se o usuário está executando a tarefa corretamente, ou para apresentar recomendações (seja como resposta a uma solicitação do aluno, ou como identificação de uma oportunidade apropriada). Os objetivos de reconhecimento de erros e apresentação de conselhos são independentes. Em uma definição ampla, agentes tutores podem incluir sistemas de ajuda sensíveis ao contexto (que dão conselhos mas não reconhecem erros) e compiladores (que tipicamente apontam os erros mas não dão conselhos). De uma forma geral, tudo que o agente tutor deve fazer é ser capaz de avaliar e responder às ações do usuário de alguma maneira.

Em muitos casos, é desejável que o agente tutor seja capaz de controlar alguns aspectos da ferramenta, o que seria útil para proporcionar o feedback apropriado ao usuário.

Em domínios em que os problemas a serem resolvidos levam um certo tempo, é necessário que a ferramenta seja capaz de restaurar algum estado anterior, para que ele possa sair do ambiente de aprendizado sem perder o trabalho.

\section{Gerenciador de Currículo}

Este módulo é responsável por decidir qual problema apresentar ao usuário. Esta decisão pode ser tão simples quanto pegar o próximo problema em uma lista preestabelecida, ou pode ser tão complexa quanto selecionar uma tarefa baseada em como as características combinam com um perfil de execução de tarefas de um usuário.

\section{Tradutor}

O tradutor manipula toda a comunicação entre a ferramenta e o agente tutor. Se existir mais de uma ferramenta ou agente tutor, o tradutor é responsável por rotear mensagens até o componente adequado. Como o tradutor precisa saber sobre as exigências de comunicação da ferramenta e do agente tutor, ele precisa ser adaptado para cada ambiente de ensino.

A vantagem deste modelo é que a ferramenta e o agente tutor podem ser completamente desenvolvidos sem conhecer os detalhes do outro. A habilidade para alterar o agente tutor independentemente da ferramenta é crucial em domínios onde a ferramenta não foi desenvolvida por nós.

\subsubsection{Considerações sobre a Arquitetura de STIs}

Como vimos, embora muitos autores concordem sobre constituição de STIs a partir de quatro modelos básicos (Modelo de Interface, Modelo do Especialista, Modelo Tutorial e Modelo do Usuário), segundo [ITSc96], não há uma arquitetura padrão para os STIs. A necessidade por 
diferentes recursos incorporados a alguns sistemas determina a criação de novos modelos que diferenciam os STIs em sua estrutura lógica, porém mantém os seus fundamentos sólidos. Estes fundamentos [Rog95] constituem basicamente em propôr situações interativas de resolução de problemas de acordo com o nível do usuário, rastrear o desempenho do usuário e intervir quando necessário, a fim de instruir o usuário em determinados princípios. 


\section{Capítulo 4}

\section{Ensino Escolar}

\subsection{Método Tradicional de Ensino}

Segundo o pesquisador Roger Schank da Universidade de Northwestern, EUA, o método tradicional de ensino é baseado na crença de que as pessoas aprendem ouvindo e memorizando as palavras de um professor e os procedimentos e as políticas de livros de treinamento [Sch97], e constitui o método de ensino adotado em escolas. Este método, segundo Schank, proporciona a memorização de informações por curto tempo. O modelo escolar, de um modo geral, nunca teve a intenção de ajudar as pessoas a adquirirem habilidades práticas, e sim, de proporcionar uma educação genérica, para que as pessoas possam buscar aplicações práticas em algum momento na vida. Porém, esta nem sempre é uma realidade, visto que parte daquilo que se aprende é esquecido com o tempo, quando limitado à teoria.

Por isso, Schank defende a idéia de que o conhecimento, para ser assimilado, deve ser complementado com a prática. Porém, muitas atividades não podem ser realizadas numa sala de aula, o que acaba gerando uma separação física entre o local da instrução e o local da prática [Kas94]. Como forma de diminuir esta distância, as instruções baseadas em computador permitem superar este obstáculo que geralmente força a separação entre a instrução e a resolução de problemas.

Segundo Schank, por trás de todo aprendizado deve existir um objetivo, seja ele o de simplesmente satisfazer um desejo ou de alcançar uma meta. Com esta finalidade, as pessoas se tornam mais abertas a aceitarem opiniões/sugestões sobre como alcançar o seu objetivo. Por isso, para que o verdadeiro aprendizado ocorra, é preciso que o objetivo seja do próprio "aprendiz" e não de outra pessoa. Porém, a maioria dos treinamentos tradicionais falham em ajudar as pessoas a atingirem os seus objetivos.

A seguir estão enumerados alguns inconvenientes do método tradicional de ensino, também adotado como método de treinamento em algumas empresas: 
- A necessidade de se dispor de um especialista sobre a área de ensino. Muitas vezes pode haver necessidade de se buscar um especialista externo, o que envolve um custo elevado (deslocamento, hospedagem e prestação de serviço).

- O treinamento é destinado a muitas pessoas ao mesmo tempo. Problemas na assimilação do conteúdo podem surgir, uma vez que o ensino não é individualizado e por isso não pode atender às particularidades de cada um, no que se refere ao ritmo de aprendizado, facilidades e dificuldades encontradas.

- As habilidades aprendidas podem ser esquecidas se não forem colocadas logo em prática.

- A ajuda nem sempre está disponível no momento em que se precisa dela.

- A utilização de manuais requer que o conhecimento seja memorizado.

Numa sala de aula, um professor experiente deveria saber identificar, a partir das respostas individuais de um aluno, qual segmento da aula necessita ser revisto, como as explicações podem ser refeitas e quais as perguntas a serem feitas ao aluno antes de oferecer mais material [Ek194]. Sabemos que este método de ensino ideal dificilmente seria adotado, diante da complexidade em se adaptar cada aula de acordo com as necessidades de cada um dos alunos. O mais próximo que se pode verificar é uma adaptação que possa favorecer a grande maioria, de uma forma geral. Por outro lado, segundo [Ek194], se o método ideal fosse adotado, pode-se considerar que o professor estaria desenvolvendo um modelo cognitivo do aluno, ou seja, um conceito sobre o conhecimento atual do aluno sobre o domínio, e teria uma variedade de estratégias de ensino à sua disposição, para serem adotadas dependendo das respostas do aluno e da natureza da informação a ser apresentada.

Aos poucos, a necessidade de se aperfeiçoar as técnicas de ensino de modo a torná-lo mais eficiente na educação tem dado espaço aos computadores que, a cada dia, têm se tornado mais comuns em escolas. A demanda por alta qualidade na educação a um baixo custo se intensificou enquanto, simultaneamente, os computadores se tornaram mais baratos, potentes e amigáveis. Por isso o interesse por ambientes de instrução baseada em computador tem crescido, e o método tradicional de ensino tem sido complementado com métodos mais práticos e interativos, na tentativa de superar as falhas como as citadas acima.

\subsection{Métodos de Aprendizado}

Um dos maiores problemas ao se desenvolver sistemas educacionais e sistemas de treinamento é a falta de uma teoria genérica de instrução [Sch97], ou seja, segundo [Lur96], os sistemas não são baseados em um modelo de aprendizado consolidado. Existem suposições sobre a maneira como as pessoas aprendem, porém, embora algumas áreas tenham sido bastante estudadas, questões importantes sobre como as coisas devem ser ensinadas pelo computador são ainda desconhecidas. Os módulos responsáveis pelo ensino muitas vezes são implementados baseados em experiências e em observações sobre o aprendizado no dia-a-dia. 
Roger Schank tem sido um dos maiores defensores desta idéia desde o final dos anos 80 , quando, juntamente com a sua equipe em Yale, composta por especialistas em Ciência da Computação e em aprendizado humano, identificou a possibilidade de se desenvolver programas educacionais divertidos como jogos, capazes de despertar maior interesse dos usuários e, ao mesmo tempo, capazes de se adaptarem às diferenças de personalidade. Através dos estudos sobre como as pessoas aprendem, a criação de sistemas eficientes para ensino e treinamento tem sido possível. Quando se fala em aprendizado, um grande erro está em assumir que aquilo que foi ensinado com clareza e sobre o qual o aluno foi testado garante que houve aprendizado. Baseados em seus estudos, Schank propõe alguns métodos de aprendizado observáveis no dia-a-dia, alguns dos quais podem ser identificados na maneira como as crianças aprendem [Sch97], [SKJ], e que deveriam ser considerados ao se desenvolver qualquer aplicação voltada para ensino ou treinamento.

\subsubsection{Aprendizado por Diversão}

Tradicionalmente, em instituições de ensino, vale a premissa de que aquilo que envolve diversão faz mal [Sch97]. Porém, ouvir palestras e decorar incontáveis fatos não são atividades divertidas e mesmo assim, não se pode dizer que sejam métodos completamente eficientes.

A diversão tende a criar um maior envolvimento do participante em relação à atividade à qual ele está sendo submetido, proporcionando um ambiente mais descontraído que desvincula, muitas vezes, da sensação de obrigação de aprender.

\subsubsection{Aprendizado por Metas}

Através da observação de como as crianças aprendem, é possível identificar semelhanças no modo como o aprendizado ocorre de maneira geral. Uma criança que está aprendendo a falar sente a necessidade de se fazer entender, de forma a conseguir aquilo que deseja.

$\mathrm{Na}$ verdade, em se considerando situações como essa, por trás do aprendizado existem objetivos: fazer as pessoas tomarem alguma atitude ou ter um pedido atendido. Por isso, observamos que se existe um objetivo, ocorre um aprendizado efetivo, desde que esse objetivo seja pessoal, e não de outra pessoa, ou seja, as pessoas estão dispostas e capacitas a aprenderem quando estão perseguindo um objetivo.

No que diz respeito a empresas, as metas dos funcionários giram em torno de fazer seu trabalho de forma melhor, de maneira a colher as recompensas pessoais, financeiras $\mathrm{e}$ profissionais relacionadas à carreira, inerentes àqueles com melhor desempenho. Neste ambiente, um treinamento que proporcione aos funcionários a chance de atingirem seus próprios objetivos, estará, ao mesmo tempo, atingindo também o objetivo do treinamento, resultando em funcionários mais bem capacitados. Porém, o que se observa ainda hoje em dia é que a maioria dos treinamentos tradicionais falham em ajudar as pessoas a definirem e atingirem seus objetivos. 


\subsubsection{Aprendizado por Experiências ou Baseado em Casos}

Aprender através de experiências está relacionado ao aprendizado por metas, pois, além de se ter um objetivo, é preciso que se considere experiências próprias para saber quais atitudes tomar, a fim de conquistar o objetivo. Por exemplo, ao se aconselhar uma criança a dividir os seus brinquedos e não brigar, provavelmente o conselho não será levado em consideração. A partir do momento em que a própria criança se der conta de que pode se dar melhor com as outras crianças se colocar os conselhos em prática, ocorre o aprendizado, ao mesmo tempo em que o objetivo é alcançado.

De acordo com [RS91], em muitos domínios complexos, o melhor método de ensino é o baseado em casos. Pode-se dizer que este método é uma extensão do método baseado em experiências, uma vez que o relato de casos geralmente se baseia em experiências, sejam elas próprias ou não.

Nesta mesma linha de aprendizado, podemos incluir a analogia [VG96], que consiste na resolução de problemas a partir de outros já conhecidos e que se sabe possuirem similaridades com o problema que se deseja solucionar. Escolas de administração e direito ensinam casos ao invés de regras. Pesquisas recentes em IA sugerem que existe um motivo psicológico válido para isso e, baseado nesta pesquisa, métodos de ensino baseados em IA que utilizam casos para ensinar têm sido desenvolvidos. Acredita-se que muitas, se não a maioria das habilidades podem ser ensinadas baseadas em casos.

Outro recurso que tem sido utilizado em muitos sistemas é o de apresentar ao usuário relatos de experiências de especialistas na área sendo treinada. Baseados nesses relatos, o usuário pode aplicar os conhecimentos adquiridos em situações semelhantes que ele venha a enfrentar.

\subsubsection{Aprendizado por Simulações (Aprender Fazendo)}

Este é um tipo de aprendizado onde as pessoas são colocadas em ambientes que simulam situações reais, e são submetidas a algum tipo de prática que pretende ensinar-lhes alguma habilidade. Para se verificar a eficácia deste método, é preciso certificar-se de que o ambiente se assemelha ao real e se a habilidade adquirida será útil. Caso contrário, o treinamento poderá não apresentar os resultados desejados. Neste caso também, é importante que se estabeleçam objetivos a serem atingidos, para que o treinamento tenha sentido e parte do aprendizado não se perca.

Este método pode ser utilizado como complemento a uma teoria, e quanto mais o aprendiz enxergar as vantagens deste recurso como forma de benefício próprio, mais qualificado ele poderá se tornar. Este tipo de ambiente garante que as pessoas possam aplicar aquilo que aprenderam.

\subsubsection{Aprendizado por Erros}

Aprender com os próprios erros é uma das melhores e mais eficientes formas de aprendizado. 
A simulação permite a interação do usuário, ao mesmo tempo em que proporciona a chance de cometer erros em um ambiente que não oferece riscos ao usuário, muito menos à empresa.

A partir do momento em que reconhecemos um erro, buscamos os meios para corrigi-lo. Muitas vezes o erro é cometido pela falta de conhecimento, e então, o aprendizado deve ocorrer.

\subsection{Surgimento dos Softwares Educacionais}

Alguns softwares de aplicação específica foram criados a fim de permitir ao aluno complementar com a prática o conhecimento teórico adquirido em sala de aula. Estes softwares, denominados softwares educacionais, segundo [Gir97], são "programas que visam atender necessidades c possuem (ou devem possuir) objetivos pedagógicos. Todo software pode ser considerado educacional, desde que sua utilização esteja inserida num contexto e numa situação de ensino-aprendizagem, onde existe uma metodologia que oriente todo o processo".

Os softwares educacionais podem ser divididos basicamente em dois grandes grupos [Gir97]: IAC (Instruções assistidas por computador), fundamentados na teoria behavioristacomportamentalista (behaviorismo: estratégias de ensino estruturadas e ênfase na rotina, considerando o ensino como sendo uma transferência organizada de conhecimento), e os Ambientes de Aprendizagem Interativa, fundamentados na teoria cognitivista-conceitual piagetiana. A história destes ambientes pode ser dividida em dois momentos: o primeiro, envolvendo as IAC, os micromundos, os simuladores e os jogos educacionais, e um segundo momento, envolvendo a IA.

\subsubsection{Micromundos}

Uma aproximação à instrução assistida por computador (IAC) centrada no aluno está na criação de sistemas baseados em micromundo, nos quais a ênfase é dada ao aprendizado e não ao ensino. O melhor exemplo deste tipo de sistema é o ambiente LOGO, criado por Papert no final da década de 70 nos laboratórios do MIT. O projeto nasceu da influência dos resultados da pesquisa de Papert, interessado na questão do ensino de Matemática, e influenciado pelas idéias de Piaget, de que é mais importante ajudar a criança a aprender a construir e depurar suas próprias teorias, do que ensinar teorias que julgamos corretas. Devido à importância deste sistema como base para desenvolvimento de outros trabalhos e como predecessor dos STIs, iremos descrevê-lo com mais detalhe a seguir.

No ambiente LOGO, o computador proporciona uma linguagem amigável para o aluno poder pesquisar e o computador responde aos comandos de maneira exata e previsível. Até certo ponto, os problemas de justificar uma grande variedade de respostas dos alunos são superados, já que a linguagem é rígida e previsível, proporcionando somente um ambiente de pesquisa para o aluno verificar relacionamentos e testar teorias. O diálogo resultante é iniciado pelo aluno e o computador não tem registro do seu progresso ou da sua compreensão. Tais 
ambientes proporcionam aos alunos as ferramentas básicas para a interação sem traçar o seu aprendizado. O computador é passivo e o aprendizado ocorre de acordo com a iniciativa do aluno [Ek194].

Embora o projeto LOGO não utilize programação de IA para construir sistemas tutorias, o projeto todo está profundamente influenciado por metodologias e conceitos de IA. Os resultados obtidos a partir do projeto LOGO revelaram dados importantes que auxiliaram a desenvolver conceitos a partir de experiências pessoais das crianças, e demonstraram a importância na depuração de erros para a construção desses conceitos.

\subsubsection{Micromundo Inteligente}

Eklund supôs em seu trabalho [Ek194] acrescentar inteligência ao micromundo LOGO. Neste contexto, supõe-se que a tela seja dividida em duas partes: uma contendo a tela original do ambiente LOGO, funcionando da mesma forma que o sistema original, e outra com uma área de prompt. O objetivo seria melhorar o sistema de duas maneiras: primeiramente, fazendo o sistema reconhecer sintaxes erradas e oferecer sugestões na área de prompt. $\mathrm{O}$ aluno teria a liberdade para aceitar a sugestão ou continuar por conta própria. Até esta fase, não se verifica a inclusão de nenhuma inteligência ao sistema. Foi somente introduzida uma assistência de nível baixo, permitindo ao aluno se concentrar mais no planejamento do que na sintaxe das instruções.

A segunda melhoria no ambiente LOGO seria a atribuição de um modelo do aluno, para que um histórico do aluno pudesse ser armazenado, à medida em que fossem usadas palavras chaves e seqüências de palavras chaves. O objetivo disto seria o de proporcionar um nível adequado de instrução quando um erro fosse cometido, ou de oferecer sugestões de seqüências alternativas de palavras chaves. Desta forma, o modelo, ao construir este histórico ao longo da interação, seria capaz de proporcionar instruções individualizadas ao aluno.

Não se verificou a implementação de tal proposta de criação de um ambiente LOGO inteligente, porém este relato tem a finalidade de ilustrar mais uma vez a importância do ambiente LOGO e sua contribuição para o desenvolvimento dos STIs, no sentido de servir como referência e inspiração para outros estudos que tem se destacado até os dias de hoje.

\subsection{A Utilização de STIs no Ensino Escolar}

Os primeiros sistemas tutoriais testados em ambiente escolar não obtiveram muito êxito devido a três motivos fortes:

- Os professores estavam acostumados a abordar os mesmo tópicos com idéias específicas;

- O computador não era capaz de modificar suas apresentações, seus exemplos e seus conteúdos conforme as respostas dos alunos; 
- O aluno ficava fechado dentro de um paradigma de aprendizagem que podia não atingir as suas necessidades individuais.

Com a incorporação das técnicas de IA aos sistemas voltados para ensino, nasceram os sistemas "inteligentes", capazes de ajustar o conteúdo das lições de acordo com as necessidades do aluno através da análise das suas respostas.

O objetivo desta dissertação é ilustrar os STIs aplicados a empresas, mais especificamente voltados para treinamento. Porém, o surgimento dos STIs de deu inicialmente com a finalidade de complementar o ensino escolar e, muitas vezes, substituir um especialista em uma área ou aplicação específica, ou seja, na verdade, muitos STIs têm a finalidade de replicar todas as atividades de um professor humano. Por isso, sentimos a necessidade de apresentar o histórico dos STIs e enumerar alguns sistemas aplicados ao ensino acadêmico para ilustrar a evolução nesta área.

\subsubsection{Exemplos de STIs voltados para ensino acadêmico}

Segundo [Gir97], os STIs possuem um marco histórico chamado SCHOLAR, considerado o clássico entre os SITs. Este sistema foi projetado e construído pela equipe do professor Jaime Carbonell, no BBN Bolt Beranek and Newman INC. - laboratório de pesquisa em Cambridge, Massachussets, no início da década de 70. O SCHOLAR é um sistema tutorial que tem o objetivo de ensinar Geografia da América do Sul, e é capaz de conduzir um diálogo de iniciativa mista com o aluno. O conhecimento está representado por uma rede semântica em cujos nós estão os objetos e conceitos geográficos. Foi responsável pelo lançamento de um novo paradigma e utilizava o método socrático como estratégia tutorial. No método socrático, o tutor ensina o aluno através de uma abordagem de exposição indireta, que consiste na oferta, ao aluno, de questões sucessivas que visa formular princípios gerais baseados em casos particulares para ele poder analisar e avaliar hipóteses, descobrir contradições e finalmente fazer inferências corretas.

O projeto SOPHIE - SOPHisticated Instructional Environment, coordenado por Brown\&Burton, se baseia no tutor METEOROLOGY, usado para ensinar predições meteorológicas. O SOPHIE funciona como um laboratório onde o aluno tem a chance de aplicar os seus conhecimentos e receber feedback, em um ambiente no qual o aluno pode testar suas idéias, tê-las criticadas e receber orientação através do ambiente de aprendizagem reativo.

O PROUST foi desenvolvido por Soloway \& Johnson em 1984 e funciona como um depurador de programas em Pascal. A partir dos erros do aluno e de suas concepções erradas, o sistema pretendia reconstruir o programa, tendo como base a idéia inicial do aluno.

O POLA [CV96] é um sistema que foi desenvolvido por Conati e VanLehn na Universidade de Pittsburgh, e tem a finalidade de modelar o estudante, realizando avaliações probabilísticas da sua performance enquanto este resolve problemas em física introdutória.

O ANDES [CGVD97] é um STI que ensina fisica newtoniana através da resolução supervisionada de problemas (coached problem solving). Este é um método de ensino de 
habilidades cognitivas no qual o tutor e o aluno colaboram para resolver problemas. $O$ ANDES é um projeto de colaboração conjunta entre a Universidade de Pittsburgh e a Academia Naval, envolvendo 10 programadores e pesquisadores. O solucionador de problemas tanto do ANDES quanto do POLA contém conhecimento sobre a argumentação qualitativa e quantitativa necessária para resolver problemas complexos de física. Entretanto, enquanto o solucionador de problemas do POLA gera seqüências simples de passos de solução, o solucionador de problemas do ANDES tem conhecimento explícito sobre os passos de planejamento abstratos que um especialista deve usar para resolver problemas, e sobre o qual o ANDES irá tutoriar alunos.

No ensino da Matemática, surgiram vários STIs, dentre os quais estão MATHPERT (MATH exPERT) de 1989, para ensino de álgebra, trigonometria e introdução a cálculo, e EMMA, também de 1989, para o ensino de equações lineares [Ek194].

O LISPITS (LISP Intelligent Tutoring System) [LC92] é um sistema baseado em instruções cuja finalidade é ajudar alunos a aprenderem a programar em LISP, ao fornecer "feedback" à medida em que os alunos compõem um programa para resolver um determinado problema. Ele foi desenvolvido por Corbett \& Anderson na Universidade de Carnegie Mellon e foi testado pela primeira vez em 1983. Desde então, tem sido utilizado como ferramenta de pesquisa, além de ser utilizado para ensinar LISP no departamento de psicologia na própria universidade, em todos os semestres desde 1984. O tutor atualmente cobre os 12 primeiros capítulos de um texto introdutório sobre LISP e inclui aproximadamente 240 exercícios. Segundo [Ek194], o LISPITS possui um conjunto de regras para a solução de problemas e uma especificação para cada exercício, ao invés de uma solução para cada um. Dessa forma, o tutor é capaz de simular as ações que um especialista tomaria em cada passo do problema. $\mathrm{O}$ tutor compara as respostas do aluno a um conjunto de respostas possíveis em relação aos erros conhecidos, a fim de identificar se o aluno está a caminho de encontrar a resposta. O conjunto completo de regras para a resolução de problemas é conhecido como modelo ideal do aluno, e representa explicitamente os objetivos das instruções. O modelo do aluno também contém um catálogo de bug.

Estudos de avaliação demonstraram a eficiência do LISPITS. Os alunos conseguem completar os exercícios com velocidade $30 \%$ maior e obtém notas $43 \%$ melhores em testes.

Apresentamos com um pouco mais detalhes o sistema LISPITS acima, com a finalidade de expôr os dados referentes ao seu estudo de desempenho, uma vez que o acesso a esse tipo de informação em relação aos sistemas é dificilmente obtido. Muitas vezes não existe uma avaliação dos sistemas, ou então os dados se restringem a fins de pesquisas internas.

Além destes sistemas, muitos outros em diversas áreas foram desenvolvidos com a finalidade de ensinar ao aluno o conteúdo de um domínio específico, e têm se mostrado altamente eficientes. Isto se deve ao fato de que tais sistemas permitem ao aluno aprender através da prática, em um ambiente onde os erros são tolerados e podem ser corrigidos, pois os sistemas guardam um histórico do desempenho do aluno e fornecem a ajuda necessária no momento certo, garantindo um ensino personalizado. 


\section{Capítulo 5}

\section{Treinamento em Empresas}

\subsection{Métodos Tradicionais de Treinamento}

Sabe-se que a princípio, a maioria das empresas utiliza métodos de ensino semelhante ao adotado em escolas, como forma de treinamento de funcionários. O mais comum deles é o "learn-by-telling", que, em geral, apresenta taxas de aproveitamento baixas por não proporcionar um ambiente prático onde se possa aplicar a teoria aprendida. Schank [Sch97] afirma que "o valor de palestras - e o valor da escola e do treinamento tradicional - é fazer com que as pessoas sejam iniciadas na direção correta".

Segundo Schank, as empresas alegam que palestras, manuais elaborados e testes para medir o conhecimento inspiram o aprendiz, catalizam novas maneiras de pensar e introduzem as pessoas a novas políticas e procedimentos. Porém, não importa o quanto isso deslumbre e inspire as pessoas. É preciso que se internalize os procedimentos a fim de se fazer um trabalho melhor, e isso pode ser conseguido a partir do momento em que se consegue colocar esses procedimentos em prática e receber ajuda quando se fracassa.

Um exemplo que pode ilustrar esta situação é reconhecer que não se pode dizer que uma pessoa sabe utilizar o computador, tendo fornecido a ela somente apostilas e aulas teóricas (como ligar o computador e acessar programas ou recursos). Se ela nunca se sentar na frente de um equipamento e colocar isso em prática, muito pouco será aproveitado. Pode ser que, passado algum tempo, não sejam mais lembrados todos os passos para chegar àquilo que ela deseja.

Outro método de treinamento muito adotado hoje em dia em empresas é o treinamento baseado em simulações, já citado anteriormente. Geralmente, este método é conhecido como "goal-based-scenarios" ou cenários baseados em objetivos. Seja ele realizado em computador ou não, terá efeito somente se as pessoas estiverem motivadas e conscientes da sua importância. Isto deve ser estimulado antes de se partir para o treinamento, uma vez que a 
experiência mostra que a maioria das pessoas gosta de se dar bem no trabalho, ao mesmo tempo em que detesta a sensação de incompetência. A partir do momento em que a pessoa passar a fazer parte do ambiente de simulação, é este quem deverá ser capaz de manter a pessoa motivada. Em ambientes computadorizados, podem ser usados, por exemplo, recursos de multimídia.

Neste tipo de treinamento baseado em cenários, porém, é comum encontramos situações em que pessoas são submetidas a ambientes que nada tem a ver com a sua realidade, principalmente quando são utilizados meios físicos externos. Um exemplo disto é esperar que líderes sejam treinados nas suas habilidades de conduzir pessoas, submentendo-as a situações como escalar morros ou aventurarem-se em trilhas. Embora esta idéia seja válida, precisamos considerar que as condições dentro de uma empresa são bem diferentes, o tipo de pressão e cobrança pode ser mais rigoroso e a ocorrência de uma falha pode ser catastrófica. Por esses motivos, um ambiente de treinamento que se assemelha ao ambiente real pode proporcionar ao funcionário vivenciar situações a que realmente ele estará sujeito no dia-a-dia.

\subsection{O Institute for the Learning Sciences (ILS)}

Com a finalidade de revolucionar o método de aprendizado e fazer algo mais útil com a sua experiência do que simplesmente desenvolver programas de computador inteligentes, Roger Shank reuniu seu grupo em Yale, especialista tanto em Ciência da Computação, quanto em aprendizado humano, e identificou a possibilidade de criar softwares educacionais para ajudar alunos a aprenderem da maneira considerada correta por ele. Estes programas seriam tão divertidos quanto jogos de computador, iriam começar com objetivos que as crianças realmente têm, acomodariam diferenças de personalidade (que afetam a maneira como as pessoas aprendem) e permitiriam cometer erros e procurar explicações sobre os erros, além de fazê-los pensar.

Ao procurar por fundos para os softwares infantis, Shank encontrou alguns executivos da Andersen Consulting, que buscavam métodos melhores, mais rápidos e baratos para treinar seu pessoal nas tarefas mais complexas. Com o apoio do Departamento de Defesa e de outras agências federais, Andersen, em parceria com Roger Schank, criou em 1989, o Institute for the Learning Sciences (ILS, Instituto para as Ciências de Aprendizado) na Universidade de Northwestern e o Learning Science Corporation (LSC, Corporação das Ciências de Aprendizado). A descoberta de novas tecnologias de ensino no ILS tem permitido ao LSC adaptar essas tecnologias para serem utilizadas por clientes corporativos na criação de softwares e role-playing scenarios (cenários de desempenho de papéis).

A finalidade destas instituições era mudar a maneira como os funcionários aprendiam. O ILS se tornou um laboratório de tecnologia educacional internacionalmente reconhecido, dedicado a aplicar os princípios da ciência cognitiva, teoria educacional, ciência da computação e IA para aperfeiçoar experiências de aprendizado e currículo. Vários sistemas de treinamento foram desenvolvidos através das tecnologias descobertas no ILS. Apesar da resistência inicial encontrada, a garantia de redução nos custos e no tempo gasto em treinamento fez com que algumas empresas reconhecessem os benefícios de se "colocar" o 
treinamento em discos "portáteis" de computador, mantendo assim seus especialistas fora das salas de aula e dentro de campo.

Sistemas para treinamento de profissionais desde vendedores e telefonistas até gerentes foram desenvolvidos, e o que se pôde verificar, segundo Schank, foi que, apesar da economia de custos ter tido precedência sobre os objetivos reais dos sistemas no momento de se decidir pelo seu desenvolvimento, as empresas reconheciam, após a sua instalação e utilização, que os benefícios reais eram o aumento na eficiência.

Em novembro de 1994, o então Learning Science Corporation deu lugar ao Cognitive Arts Corporation, que completou seus 5 anos como líder no desenvolvimento de soluções de aprendizado corporativo. Roger Schank é o presidente e o chefe de tecnologia do Cognitive Arts, considerada uma divisão comercial do ILS, que se beneficia de US\$40 milhões de fundos investidos no ILS na última década [Jon99].

A Andersen Consulting foi a primeira empresa a implementar os sistemas de aprendizado virtual, apresentando a oportunidade para transformar o sistema de aprendizado de toda a organização. Um dos motivos que impulsionou isso foi o fato de que seus gerentes reconheceram que treinar os funcionários estava ficando bem mais complexo do que no passado. Novas tecnologias, crescimento rápido e outras questões exigiram habilidades de consultoria mais amplas e profundas, e estas habilidades não eram simples de serem ensinadas nem fáceis de serem aprendidas. Outro motivo era a redução de custos. A Andersen investe mais de US\$ 200 milhões por ano no treinamento de seus funcionários. Grande parte deste investimento era voltado a levar profissionais de toda parte do mundo para as suas instalações, e a perspectiva de se poder utilizar sistemas de treinamento baseados em computador representava a possibilidade de economizar milhões de dólares.

\subsubsection{Sistemas Inteligentes baseados em tecnologia do ILS}

Embora não seja preocupação do ILS incorporar inteligência em seus sistemas de treinamento, mas sim, projetar, da maneira mais eficiente possível, ambientes de aprendizado eficazes [Jon99], podemos encontrar alguns sistemas inteligentes classificados como Intelligent Learning-By-Doing Environments (ILDE) desenvolvidos no ILS. De uma maneira geral, todos os trabalhos desenvolvidos no instituto ajudaram a impulsionar as pesquisas em STIs na última década, e ainda servem de referência para muitos projetos, principalmente na área de treinamento em empresas, onde foram um dos pioneiros.

De uma forma geral, os ILDE são baseados em dois aspectos da teoria de como as pessoas pensam e aprendem [Kas94].

1. As pessoas argumentam melhor a partir de casos específicos ao invés de regras abstratas.

2. As pessoas aprendem melhor fazendo - particularmente cometendo erros, descobrindo esses erros e os corrigindo - e não através da memorização por hábito ou através da observação passiva da atuação de um especialista. 
Devido à importância dos trabalhos desenvolvidos no ILS, vamos enumerar alguns sistemas inteligentes originados a partir da sua tecnologia, e que têm aplicações voltadas para empresas.

\section{ESS - Engagement Simulation System}

O ESS é um ILDE destinado a consultores de empresas [KB91]. Este tipo de sistema oferece aos usuários uma ambiente interativo de tarefas e um conjunto de métodos de ensino (camada tutorial) [Kas94].

O ESS treina consultores de empresas novatos a interagirem de maneira eficaz com os clientes através da simulação do mundo social no qual o consultor deve operar, e permitindo ao usuário praticar desempenhando papel de consultor no mundo simulado. $\mathrm{O}$ ambiente de tarefas coloca o usuário no papel de aprendizado ativo, apresentando uma atividade desafiadora relacionada ao assunto sendo ensinado. Os módulos de ensino monitoram a interação do usuário com o ambiente de tarefas. Com base nas observações, os módulos de ensino aconselham e orientam o usuário, e manipulam o ambiente de tarefas, a fim de aumentar a experiência de aprendizado. Um módulo contador de estórias, por exemplo, responde a certas interações entre o usuário e o mundo simulado através da apresentação de estórias sobre situações ocorridas no passado, obtidas através de consultores experientes. Um outro módulo de ensino apresenta ao usuário análises políticas da situação e sugere estratégias políticas.

As simulações sociais são particularmente apropriadas para ensinar habilidades interpessoais complexas, exigidas em domínios como diplomacia, negociação e administração. Por exemplo, consultores inexperientes precisam aprender habilidades delicadas, necessárias para serem bem sucedidos ao interagirem com clientes. Tais habilidades incluem:

- Descobrir as estruturas oficiais e extra-oficiais das organizaçôes do cliente.

- Lidar eficientemente com diferentes tipos de personalidades dentro da organização, e extrair das pessoas as informações necessárias para fazer recomendações.

- Fazer recomendações de maneira convincente mas não ameaçadora.

Estas habilidades são difíceis de se ensinar de maneira abstrata. A maneira padrão para ensinar os consultores é através da experiência, porém, cometer erros em clientes pode ter um custo muito elevado. O objetivo do sistema é proporcionar ao consultor praticar - e cometer erros - com clientes simulados e não reais.

O ambiente de tarefas do sistema é completo, com gerentes, colegas e clientes simulados, que atuam baseados em metas, crenças, expectativas e atitudes. $\mathrm{O}$ ambiente ainda oferece todas as ferramentas necessárias a um consultor, a fim de que o usuário do sistema possa contar com toda a gama de atividades que estão disponíveis no trabalho. Dentre as ferramentas estão relatórios de pesquisas, telefone simulado, entre outros, que podem servir para o usuário consultar e marcar compromissos, como visitar clientes. 
Um projeto é atribuído ao usuário por um gerente simulado, que proporciona o mesmo tipo de orientação e feedback que seria proporcionado por um gerente no mundo real. Para parecer mais realista, desenhos e fotos são utilizados para mostrar como são os clientes e seus escritórios.

Do mesmo modo, para fazer o mundo simulado se comportar de maneira realista, é necessário construir um modelo aceitável de agentes inteligentes, e isso se dá a partir da utilização da teoria de IA. De forma análoga, os módulos de ensino também requerem teorias de IA.

\section{Utilizando o programa}

A tela principal do sistema apresenta as seguintes seções:

- O cenário corrente: este espaço é destinado a apresentar gráficos que representam o meio físico do usuário, e compreende a maior porção da tela. Inicialmente, é apresentada a sala do usuário. Ao iniciar a leitura de algum documento, o mesmo aparece na tela em alta resolução, e ao se comunicar com um agente, o usuário pode ver uma foto escaneada, que permite visualizar o sexo do agente e o modo como está vestido.

- O construtor de ação: este é o painel de controle que permite ao usuário especificar ações que ele deseja executar ou construir declarações que o usuário deseja fazer a outros agentes. Os três tipos de ações mais comuns no mundo simulado são dizer alguma coisa a alguém, ler alguma coisa ou ir a algum lugar. A construção dessas ações é feita a partir da utilização de um conjunto de itens de vocabulário abstratos, cuja vantagem é forçar o usuário a construir ao invés de selecionar o que falar, ao mesmo tempo em que restringe o domínio daquilo que pode ser dito de acordo com o que os agentes no sistema podem entender.

- A janela de diálogo: o diálogo que ocorre entre o usuário e os agentes da simulação aparece nesta área.

- As luzes indicadoras: este painel sinaliza ao aluno quando um dos módulos de ensino tem algo relacionado à situação corrente para apresentar. Ao clicar em cima da luz, o usuário pode interromper a simulação para que o sistema apresente o caso.

- O monitor de progresso: é representado por um ícone de um consultor móvel, que indica o caminho da sua carreira, podendo progredir ou regredir, de acordo com as ações executadas pelo consultor.

\section{Mecanismos de orientação e feedback}

Este tipo de sistema baseado em simulação oferece duas categorias de orientação: feedback dentro da simulação e feedback fora da simulação.

- Feedback dentro da simulação: É o resultado obtido através das ações tomadas, como por exemplo, conseguir uma informação desejada ou descobrir a coisa certa a 
fazer através da observação dos resultados das ações incorretas. Pode ainda ser algo mais explícito como conselhos ou críticas do gerente ou de colegas. A simulação pode proporcionar feedback sem a intervenção de um módulo de ensino explícito, porém este módulo pode intensificar o feedback através do ajuste da simulação para garantir que o usuário enfrente situações desafiadoras.

- Módulos de ensino - feedback fora da simulação: É o feedback cuja origem está fora do escopo da simulação, como no caso em que o módulo de ensino pode ocasionalmente fazer comentários úteis, dar orientação ou apresentar casos à medida em que observa a interação do usuário com a simulação. Dentro deste sistema estão vários comentaristas e instrutores operando independentemente, cada qual proporcionando uma forma diferente de feedback.

\section{Simulação}

Um exemplo de simulação entre usuário e sistema pode ser encontrado em [KB91]. Os clientes simulados, assim como outros agentes que interagem com o usuário, devem aparentemente compreender e reagir à linguagem do usuário, demonstrar humores e emoções, reagir a observações e ter agendas e expectativas que sejam semelhantes ao mundo real. Os estados mentais dos agentes são representados em termos de características tais como observações sobre o que os agentes vêem ou ouvem, atitudes que representam o que um agente sente em relação a outro agente, objetivos que representam o desejo de executar ações ou alcançar um estado, e expectativas que representam as crenças de um agente sobre outro agente ou aspectos do mundo simulado.

Para cada indivíduo, o estado mental atual é representado pelas características relacionadas a cada outro indivíduo conhecido por ele no mundo simulado. A cada instante da simulação, cada agente decide se existe alguma ação apropriada, com base no seu estado mental ou em novas observações sobre o mundo simulado.

Embora nenhuma simulação tenha perfeita fidelidade quando o ambiente simulado possui componentes tão complexos quanto seres humanos, e muito menos possui uma interface para linguagem natural, o sistema de treinamento de simulação social baseado em computador é mais apropriado quando comparado a outros métodos.

Basicamente, existem três métodos de ensino de tarefas sociais:

1. Instrução direta - é baseada em leituras e palestras e não se mostra muito eficiente quando o aluno é um simples leitor ou ouvinte, pois o conteúdo ensinado será provavelmente esquecido. No ESS, os módulos de ensino transmitem instruções diretas, porém o fazem no contexto de uma tarefa em execução, no qual o usuário está ativamente envolvido.

2. Observar uma pessoa experiente executando a tarefa - permite visualizar na prática, situações da vida real, porém o aluno continua passivo, e nem sempre as situações abordadas cobrem as atividades vividas no dia-a-dia. Além disso, muitas vezes, não é possível se interromper a encenação para esclarecer dúvidas no momento em que elas surgem. Por outro lado, numa simulação, pode-se manipular e adaptar o 
ambiente de acordo com cada usuário, que pode ainda ser introduzido a diferentes cenários e culturas, a fim de que possa verificar como suas ações podem afetar os diferentes ambientes.

3. Encenar com outros colegas - embora este tipo de interação seja o que mais se assemelha à simulação em computador e tenha ainda a vantagem de permitir diálogos em linguagem natural, nem sempre as pessoas envolvidas possuem a experiência necessária ou sabem desempenhar o papel dos agentes do mundo real. Além disso, este tipo de atividade pode inibir as pessoas ao enfrentarem situações de risco ou situações que pareçam tolas às outras pessoas, impedindo, assim, que muitas situações sejam abordadas.

Com base nestas comparações, notamos que em vários pontos a simulação baseada em computador se mostra mais eficiente que os outros métodos, embora a tecnologia existente imponha ainda algumas limitações.

Seguindo este trabalho, algumas ferramentas que permitiriam inserir agentes sem a necessidade de programação estavam sendo desenvolvidas pelo mesmo grupo de [KS91].

\section{Projeto CASPER}

O Casper é um ILDE (Intelligent Learning-By-Doing Environment) [Kas94] que foi criado com a finalidade de treinar representantes de serviços ao consumidor de uma companhia pública de água britânica, a diagnosticarem problemas relatados pelos consumidores ao telefone. Embora esta atividade envolva a interação com clientes, a personalidade do cliente no sistema não é tão importante quanto seria em atividade de vendas e, portanto, a simulação do cliente não precisa ser tão complexa quanto o componente tutorial, que requer habilidades técnicas e raciocínio complexo de causa. Além de apresentar estórias contadas por especialistas, o tutor Casper envolve o usuário em diálogos mais interativos baseados no estilo Socrático, que ajuda o usuário a reexaminar seu raciocínio e descobrir seus próprios conceitos errados.

O Casper foi projetado tanto para proporcionar a compreensão de um dispositivo complexo, quanto para ensinar habilidades de diagnóstico de processos de resolução de problemas. Para tanto, ele conta com um ambiente onde o tutor observa os erros táticos (tais como fazer perguntas alarmantes) e os erros no conhecimento do domínio (tais como não perceber que uma pequena evidência exclui uma certa causa do problema).

Os representantes de serviços ao consumidor (RSC) que o Casper foi projetado para treinar são responsáveis por atender ligações feitas por clientes com reclamações sobre o sistema de água, perguntas de interesse geral, informações sobre contas e até ameaças. Porém, esta primeira fase do sistema está limitada a lidar com reclamações e indagações sobre a qualidade da água.

\section{Interação do usuá rio com o cliente}

Ao receber a ligação de um consumidor descrevendo o seu problema, geralmente relacionado à percepção de alguma anormalidade com a água saindo da torneira, o RSC deve fazer as 
perguntas certas, diagnosticar a causa do problema, se for possível, e indicar uma solução apropriada. A solução pode ser instruir o consumidor a fazer algo ou então enviar um funcionário para investigar melhor o problema ou fazer consertos. Nesta atividade, a causa do problema pode ser dificil ou impossível para o consumidor identificar diretamente, e por isso, o RSC deve deduzir a causa do problema, combinando evidências indiretas e muitas vezes probabilísticas. É importante que o RSC conheça bem o funcionamento do sistema de água, desde a origem, o tratamento, o armazenamento e a distribuição. Além disso, o RSC deve entender o mecanismo de como desenvolver hipóteses sobre as causas ocultas de fenômenos observados - por exemplo, como procurar por evidências, perceber pistas e escolher entre hipóteses alternativas quando um consumidor liga para reclamar sobre a cor da água.

Para ajudar o RSC no seu trabalho, o Casper oferece o Sistema de Contato com o Cliente (SCC), que pode servir para consultar informações relevantes no diagnóstico de um problema, como determinar a origem da água, ou a ocorrência de algum trabalho no sistema de água do bairro.

Além da simulação e do tutor, o Casper oferece ao usuário um mapa hipermídia do sistema de água, que serve como uma ferramenta extremamente útil. O mapa está disponível ao usuário a qualquer momento, caso seja necessário obter informações para atender um telefonema simulado.

O ambiente simulado em Casper oferece interação com o consumidor ao telefone e com o SCC, assim como numa interação no mundo real. À medida em que o usuário entra com informações no SCC simulado, o tutor Casper monitora a atividade e utiliza as informações para ajudar o usuário a corrigir erros no seu próprio raciocínio.

\section{Recursos de comunicação}

No Casper, a comunicação do consumidor simulado com o usuário é feita através de clips de áudio, que permitem sentir o tom de voz do consumidor, determinando fatores importantes, tais como o seu nível de ansiedade. Simultaneamente, o Casper exibe o diálogo numa janela que permite ao usuário consultar quando necessário.

Por outro lado, a comunicação do usuário com o consumidor pode ocorrer através de duas interfaces. A primeira é um conjunto hierárquico de menus, denominado "utterance constructor", que pode ser utilizado para se construir declarações, e a segunda alternativa é digitar a frase diretamente numa área reservada para este fim, e verificar se o sistema, utilizando uma tecnologia de processamento de linguagem natural denominada "indexed concept parsing", consegue encontrar algo em seu repertório que se relacione à questão do usuário. Exemplos de simulações entre usuário e sistema podem ser encontradas em [Kas94].

\section{O tutor em Casper}

O tutor em Casper não apresenta respostas diretas aos problemas, mas sim, tenta conduzir o usuário através de uma corrente de raciocínio apropriada. Desta forma, ao invés de fornecer a 
solução para o problema simulado do usuário, o tutor o ensina a resolver problemas semelhantes.

A invocação do tutor se dá de duas formas. A primeira delas é a invocação explícita feita pelo usuário através de uma opção disponível na tela do sistema, e a segunda consiste na intervenção automática do tutor em resposta a alguma ação. Quando isto ocorre, o tutor não anuncia simplesmente o erro cometido pelo usuário e apresenta o passo a ser tomado. Ao invés disso, ele faz com que o usuário explique seu raciocínio, e utiliza seu modelo do domínio para fazer as críticas.

Para ser capaz de tutoriar, o Casper possui dois tipos principais de conhecimento. Primeiramente, o tutor tem acesso a estratégias independentes de domínio para decidir quando tutoriar e como lidar com as interações de ensino. Para implementar essas estratégias, o tutor acessa o segundo tipo de conhecimento, que é o conhecimento do domínio específico.

O Casper inclui um conjunto de ferramentas de autoria que podem ser utilizados para desenvolver as estratégias independentes do domínio e os modelos do domínio específico. Aplicar o tutor a um novo domínio requer o uso de ferramentas para a autoria de um novo modelo do domínio, e talvez para adaptar as estratégias genéricas. Para tanto, nenhuma programação é necessária.

\section{Conclusão}

Um teste piloto do sistema descrito está sendo realizado com funcionários de uma empresa de água que patrocinou o seu desenvolvimento. Neste ambiente, os usuários variam quanto ao tempo levado para completar um cenário, porém a média está em aproximadamente 30 minutos para cada cenário. Logo, os seis cenários proporcionam 3 horas de treinamento. $\mathrm{O}$ sistema atualmente contém aproximadamente duas horas de vídeo de especialistas (aproximadamente 80 clips, geralmente entre 45 e 90 segundos de duração).

Os verdadeiros méritos do projeto Casper estão na arquitetura de ambiente de aprendizado genérico construída e nas ferramentas desenvolvidas para suportar implementações futuras dentro da arquitetura.

\subsection{Novas Perspectivas para o Treinamento em Empresas}

Segundo Schank [Sch97], o sistema de treinamento em empresas está falido. A maneira com que os funcionários são treinados para adquirirem habilidades profissionais não tem nada a ver com a maneira com que as pessoas realmente aprendem, e se assemelha ao método tradicional de ensino adotado em escolas, que consiste em "learn-by-telling" (aprender através do que é dito). Os treinadores contam com palestras e provas, memorização e manuais, como se toda informação apresentada ficasse gravada na mente das pessoas, tornando novatos em especialistas instantaneamente. 
Este panorama tem mudado lentamente, à medida em que as empresas têm percebido que existem recursos mais eficientes e capazes de proporcionar ambientes mais interativos e atraentes aos usuários, ao contrário de salas de palestras ou apostilas de estudo.

Com base em [Net98] e [Cal99], apresentamos um estudo dos investimentos na área de treinamento em algumas empresas no Brasil, embora não sejam descritos os recursos e os métodos utilizados por elas. Este estudo visa ilustrar a valorização que a área de treinamento vem tendo, o que favorece a entrada de tecnologias como os STIs que vimos estudando.

\subsubsection{Investimentos na área de treinamento}

Segundo Luis Edmundo Prestes Rosa, diretor de recursos humanos do grupo ACCOR, "há muito academicismo no processo de educação executiva, e a maioria dos programas não consegue levar os conceitos à prática". De um modo geral, há muito desperdício na manipulação do dinheiro gasto com treinamento. Uma parte apreciável das verbas é gasta com os gurus de auto-ajuda, que têm sua vez nos circuitos de conferências e seminários corporativos. Segundo o professor Luis Carlos Ferreira de Carvalho, diretor de atendimento ao cliente da Fundação Dom Cabral de Belo Horizonte, o mais renomado centro de educação gerencial brasileiro, "muitas vezes o treinamento está distanciado das necessidades estratégicas da empresa".

O aprendizado efetivo se dá quando se tem a oportunidade de fazer, falhar e praticar, ou seja, através de "learn-by-doing" (aprender fazendo). Porém, esta prática deve proporcionar simulações que reflitam situações reais, e não, por exemplo, exercícios de sobrevivência na selva ou escaladas de muros e montanhas, o que é comum em treinamento comportamental. Segundo José Carlos Figueiredo, diretor de recursos humanos da holding que controla a empreiteira Camargo Corrêa, “... essas práticas não acrescentam um centavo ao resultado da empresa" [Net98].

Segundo os editores da revista Business Week, o valor gasto com treinamento em empresas americanas chega à cifra de 44 bilhões de dólares/ano. No Brasil, porém, não há nenhum levantamento remotamente parecido. O que se sabe é que, em 1997, as 500 maiores empresas brasileiras, listadas por Maiores e Melhores da Exame, gastaram 650 milhões de dólares em treinamento, segundo uma pesquisa do Saratoga Institute, de São Paulo. Em 1996, o investimento foi de 580 milhões.

À medida em que as empresas têm passado a valorizar o aprendizado e o aperfeiçoamento como ferramentas competitivas, seus programas de treinamento têm merecido mais importância e maiores investimentos. De acordo com [Ca199], as empresas têm percebido que precisam manter um quadro de funcionários altamente qualificado, a fim de reter os funcionários e enfrentar a concorrência. Um dos caminhos para fazer com que os talentos internos vistam a camisa da corporação é proporcionar condições para melhorar continuamente o desempenho e o desenvolvimento profissional. Muitas empresas estão dando andamento a programas e criando centros de treinamento para facilitar o acesso ao conhecimento e à tecnologia de suporte organizacional que ajudem a alcançar os objetivos corporativos. 
Instituições como o BankBoston são bons exemplos de como o funcionário tornou-se prioridade máxima. Foi investido $\mathrm{R} \$ 1,5$ milhão na construção de um centro de treinamento, no prédio do banco na capital paulista, inaugurado em abril de 1999, e batizado de BostonSchool. No mesmo ano, foram reservados $\mathrm{R} \$ 3$ milhões para treinar funcionários. A tecnologia de apoio são os programas de auto-aprendizado, bastante difundidos atualmente nos Estados Unidos. Eles vão desde cursos completos de diversos idiomas à iniciação à área de informática. A diretora adjunta de desenvolvimento organizacional do BankBoston Denise Moreira Asnis divulga terem passado até outubro de 1999, 1.790 funcionários, totalizando 108 turmas treinadas, e afirma que "sem educação perdemos a liderança do mercado".

A operadora carioca de telefonia celular ATL, que vinha perdendo profissionais para os concorrentes, também optou por investir no desenvolvimento profissional para gerar satisfação e reter o quadro de funcionários, segundo relato da gerente de treinamento e desenvolvimento Andrea Krug. Até o final do ano de 1999, o investimento de aproximadamente R\$900 mil possibilitou o treinamento de 987 funcionários. Numa outra etapa, 54 gerentes e diretores também foram treinados. O programa teve como base informações para aprimorar o trabalho em equipe, além de modelos de gestão e qualidade. Os treinamentos para todos os funcionários são subdivididos em categorias como qualidade, técnico e desenvolvimento.

Em São Paulo, a operadora de telefonia celular BCP destinou $\mathrm{R} \$ 1,7$ milhão para treinamento no ano de 1999. De acordo com Marisa Bueno, gerente de educação e desenvolvimento corporativo da operadora, a $\mathrm{BCP}$ mantém um grupo de $\mathrm{RH}$ composto por nove pessoas, responsável pelos treinamentos na área corporativa, vendas e atendimento.

A empresa de consultoria PriceWaterHouseCoopers decidiu investir no desenvolvimento profissional criando centros de treinamento na Argentina (Buenos Aires) e no Brasil (São Paulo, Ribeirão Preto e Rio de Janeiro). Através do Lotus Notes, que é utilizado como plataforma de comunicação para inscrições e autotreinamento, os funcionários têm acesso a toda a base de títulos multimídia para ampliar seus conhecimentos, podendo realizar os cursos de suas mesas de trabalho ou em uma sala especialmente preparada, com computadores e programas de treinamento. Com mais de 2 mil funcionários, o objetivo da consultoria é proporcionar um mínimo de 120 horas em cursos. Na avaliação de Ana McLoughlin, gerente de desenvolvimento de talentos da empresa para a América Latina, o treinamento não é um benefício e sim um investimento, e afirma ainda que "quanto maior o investimento, maior a qualidade dos serviços prestados".

De acordo com Sarah Borges, gerente de desenvolvimento de pessoal da Prolan, empresa integradora de redes, uma base de treinamento e desenvolvimento profissional de funcionários está sendo construída. A idéia é que cada departamento destine, dentro o seu orçamento, recursos específicos para o desenvolvimento de talentos. Ainda no início de um programa de treinamento que, além da qualificação, visa reter seus funcionários, existe a intenção de proporcionar aos 176 empregados, cursos específicos para cada função.

Os altos investimentos feitos pelas empresas na área de treinamento demonstram a importância atribuída à capacitação de funcionários. $\mathrm{O}$ crescimento desta cultura nos faz deduzir que há espaço para novas tecnologias que permitam incrementar os recursos utilizados 
atualmente, no sentido de tornar o treinamento mais eficiente e facilmente disponível aos funcionários a que eles se destinam.

Apesar da grande maioria das empresas ainda adotar o método de treinamento tradicional, sabemos que as empresas não têm condições de permitir falhas em massa no ambiente de trabalho. A criação de um lugar seguro para cometer falhas e aprender pode resolver este tipo de problema. A realidade virtual das simulações em computadores atende esta necessidade, uma vez que tem a finalidade de proporcionar ambientes que ofereçam situações reais e sejam adaptáveis a cada usuário.

Os ambientes virtuais estão conquistando cada vez mais seu espaço, principalmente em países como os Estados Unidos e o Japão. Os sistemas contam com recursos de multimídia, que são visualmente atraentes, fáceis de usar e representam alta tecnologia. Porém, alguns sistemas não são muito melhores que os treinamentos de "baixa tecnologia"; somente tem uma aparência melhor, porém não passam de meros "viradores de páginas eletrônicos". Ainda assim, há uma grande receptividade em relação a programas de treinamentos baseados em computador.

Os STIs representam uma das categorias de sistemas que atendem a praticamente qualquer área de treinamento, desde simulações, como no caso da NASA, até treinamento para cargos específicos dentro de uma empresa. Embora os STIs ainda não sejam uma realidade em empresas no Brasil, os gastos em treinamento observados em algumas corporações demonstram que há disponibilidade de recursos financeiros e há interesse em se oferecer treinamento com tecnologia e eficiência.

Lentamente, tem-se reconhecido que o treinamento não representa somente uma necessidade do "custo de se fazer negócio", segundo Shank, mas sim uma maneira de se ganhar vantagens competitivas.

\subsection{Treinamento baseado em STIs}

Quando o termo STI foi introduzido por Sleeman e Brown em 1982 com a finalidade de distinguir esses sistemas emergentes dos sistemas baseados em IAC tradicionais, o enfoque sobre o aluno passou a ser voltado sobre o "aprender fazendo" (learning-by-doing). Este método de aprendizado acabou sendo incorporado aos STIs, uma vez que estes sistemas têm como uma das características, proporcionar ambientes práticos para ensino e treinamento.

No mundo corporativo, quanto mais baixo o nível de habilidade, maior a tendência da empresa treinar pessoal através de algum método de "aprender fazendo". As pessoas aprendem a operar uma máquina através da observação e monitoramento de um especialista e da prática sobre aquilo que foi observado. Além disso, a melhor maneira de se aprender como realizar um trabalho é simplesmente tentando realizá-lo, mesmo sem nenhum preparo particular, mas com um especialista disponível para ajudar quando necessário [Sch].

Porém, existem dois importantes motivos pelos quais o "learn-by-doing" não é o método educacional mais comum. 
1. É difícil se implementá-lo sem dispositivos onde "fazer" ("doing devices"), como por exemplo, ensinar história ou literatura "fazendo". Do mesmo modo, quando o dispositivo é extremamente caro ou sem segurança, o learn-by-doing também é descartado.

2. Educadores e psicólogos muitas vezes não entendem por que o learn-by-doing funciona e, por isso, acabam não se identificando com ele. Eles não conseguem dizer exatamente o que este método ensina, ou supõem que ele ensina habilidades práticas, enquanto eles se preocupam com os fatos.

Transpondo esse problema para o ambiente corporativo, os STIs também enfrentam certa resistência por parte de educadores, treinadores, empresas e usuários, que se sentem inseguros e desconfiados em relação a essa nova tecnologia. Essa resistência tem impedido o sucesso no desenvolvimento dos STIs, que há muito tempo, têm sido vistos como uma promessa na área de treinamento acadêmico e corporativo.

Usuários a serem treinados geralmente resistem ao uso de STIs muitas vezes porque já receberam promessas anteriores no passado e encaram esta tecnologia como mais uma oportunidade para a empresa desapontá-los. Instrutores que devem usar os STIs como parte do seu programa de treinamento, assim como desenvolvedores responsáveis por criar atividades de aprendizado significativas dentro dos STIs, sentem-se ameaçados tanto em relação ao seu modo usual de operação, quanto em relação à estabilidade do seu emprego. Gerentes que devem pagar pelo desenvolvimento desses sistemas, ao olharem para os custos de desenvolvimento, resistem a essa tecnologia alegando que o desenvolvimento e a manutenção tem custos muito elevados [Blo95].

A maneira de se lidar com toda essa resistência envolve a combinação de atributos como a participação, educação e socialização, ou seja, fazer com que as pessoas sintam-se confortáveis em relação à nova tecnologia, e tenham a sensação de propriedade sobre o sistema. Além disso, os desenvolvedores de STIs devem se tornar agentes de mudança organizacional, caso a tecnologia de STIs seja adotada com sucesso no mundo real. No desenvolvimento do sistema LEAP para treinamento de pessoas falando ao telefone [Blo95], observou-se que é preciso reunir desde cedo no projeto, pessoas usuárias e favoráveis a novas tecnologias, incluindo-as em todas as decisões de projeto e desenvolvimento. Em seguida, os desenvolvedores devem estudar que impacto a adoção dessas novas tecnologias irá causar sobre a maneira de trabalho existente ou a tradicional (neste caso, o treinamento). Por último, é preciso gradativamente se expandir o envolvimento, abordando cada vez mais pessoas, promovendo assim uma mudança organizacional.

Lidar com preocupações gerenciais em relação aos "altos custos" desta tecnologia requer não somente a educação, participação e socialização enumeradas acima, mas também o empreendimento de análises compreensíveis de custo-benefício, para demonstrar os benefícios de longo prazo e redução de custos inerentes a adoção desta tecnologia, assim como as avaliações empíricas da eficiência desses sistemas. 


\subsection{Aplicações de STIs fora do ambiente acadêmico}

Na última década, os STIs saíram dos laboratórios para as salas de aula e ambientes de trabalho, onde muitos têm se mostrado eficientes.

Apesar da maioria dos STIs existentes destinarem-se ao ensino acadêmico, podemos encontrar cada vez mais aplicações voltadas ao treinamento de pessoas fora desse meio.

Os exemplos mais comuns são os classificados dentro da categoria de simuladores de dispositivos e treinamento sobre equipamentos [Mur99]. De uma maneira geral, esses sistemas apresentam partes de equipamentos ao usuário, que deve identificar seus componentes, executar passos de operação ou de manutenção, ou diagnosticar falhas no comportamento do dispositivo e consertar ou substituir as partes implicantes. Este tipo de habilidade é relativamente comum e genérica, e desta forma, as ferramentas de desenvolvimento que se especializarem nesta área deverão ser amplamente utilizadas. Os usuários de sistemas tutores pertencentes a esta categoria irão "aprender fazendo" (learn by doing). Estes tutores são ambientes de aprendizado voltados à prática de habilidades.

As simulações em computador podem viabilizar a integração entre instruções e resoluções de problemas em casos onde isso seria difícil de se conseguir de outra maneira. Além disso, apresentam vantagens tanto ao usuário quanto à empresa, já que as simulações possibilitam a prática de tarefas em ambientes onde se pode correr riscos ou cometer erros e ser exposto às conseqüências negativas dos erros, sem causar danos reais. Uma outra vantagem é a possibilidade de se suspender a simulação pelo tempo necessário, para que se possa receber instruções em qualquer ponto da atividade prática. Estas instruções estão fortemente integradas à atividade do usuário [Kas94].

\subsubsection{Exemplos de sistemas}

O Shell RIDES, descrito com mais detalhes na seção 6.5.2, é um exemplo desta categoria de sistemas, e foi utilizado para implementar aplicações como as descritas em [FH96]:

- Tutor para operações de Controle de Tráfego Aéreo

Neste sistema, o usuário é posicionado na torre de controle, e o tutor consiste de diversos cenários de aeronaves solicitando instruções de movimento, exigindo atuação com objetivos variando de simples a complexos.

- Tutor para Resolução de Problemas com o trem de Aterrissagem de Avião

Este tutor consiste de lições que ensinam sobre partes do sistema, suas localizações e sua relação funcional com outras partes do sistema. Além disso, contém lições que ensinam os usuários a resolverem inúmeros problemas em um ambiente prático supervisionado. 
Dentro desta categoria, ainda podemos enumerar outras ferramentas [Mur99], tais como XAIDA, que suporta outros domínios além dos simuladores de dispositivos, e o SIMQUEST, que suporta modelos mais aprofundados sobre o funcionamento de um dispositivo.

Um outro exemplo de sistema tutor para fornecer instruções relacionadas a operação de dispositivo é o STI desenvolvido para ensinar um adulto a programar um aparelho de videocassete para gravar programas de televisão automaticamente, e que está descrito em [Mar91].

Recentemente, a empresa de consultoria Booz-Allen \& Hamilton [BAH97] firmou um contrato no valor de US\$25 milhões com o Air Force Human Systems Center no Brook Air Force Base em San Antonio, no Texas, para desenvolver um STI. Pelo contrato, a empresa irá projetar, desenvolver, testar e avaliar uma série de sistemas de manutenção de tráfego aéreo e outros sistemas avançados de treinamento. O STI deverá oferecer treinamento em tempo real através da simulação de problemas complexo de manutenção, utilizando tecnologia de multimídia interativa. Como parte deste programa, a Booz-Allen está implantando um ambiente de desenvolvimento de software em McLean, Virginia, para desenvolver sistemas complexos de treinamento baseado em multimídia. O contrato foi estabelecido em 1997, com prazo de 5 anos. Tentamos entrar em contato com as pessoas responsáveis pelo projeto a fim de obtermos maiores informações a respeito do andamento do mesmo, porém não obtivemos resposta.

Outras categorias de sistemas para desenvolvimento de STIs podem ser encontradas em [Mur99], agrupadas de acordo com o tipo de STI que elas produzem.

\subsection{Aplicações de STIs para treinamento em empresas}

Um dos fatores que tem impedido o crescimento da cultura de utilização de STIs para treinamento em empresas tem sido os custos relativamente elevados e a necessidade de especialistas em ensino e especialistas no domínio para o desenvolvimento de uma aplicação. Porém, tem se verificado que esse panorama vem mudando, uma vez que os ambientes de desenvolvimento mais recentes contam com a flexibilidade de permitir a autoria de vários sistemas utilizando a mesma ferramenta, e de maneira cada vez mais simples. A tendência é que se busque desenvolver ferramentas que não exijam conhecimentos de especialistas como programadores ou técnicos ao se desenvolver uma aplicação. Isso vem permitir que os STIs conquistem o seu espaço em meio aos recursos utilizados em empresas na área de treinamento.

Vamos relacionar alguns sistemas desenvolvidos para aplicações em empresas, dentre os quais o CALAT e o LEAP são voltados para ambientes de rede.

\subsubsection{WITS (Welding Intelligent Tutoring System)}

O WTTS é um STI baseado em realidade virtual [Tam96], que foi desenvolvido para oferecer um ambiente para treinamento passo-a-passo de trabalhadores em solda de termo-alumínio. Este sistema foi desenvolvido na Universidade McGill no Canadá utilizando o COOL 
(CLIPS" Object Oriented Language, onde CLIPS é uma ferramenta para sistemas especialistas, desenvolvida pelo SW Technology Branch da NASA, no Lyndon B. Johnson Space Center). O primeiro estágio do WITS é um sistema especialista baseado em conhecimento (KBES), também desenvolvido na Universidade McGill, e forma a base para o sistema final.

Como um STI, o WITS possui uma arquitetura que oferece:

- Adaptabilidade no sentido de ter sido projetado para suportar múltiplos usuários simultaneamente, cada um com uma estação de trabalho com realidade virtual completamente equipado, ou suportar diversas interfaces de hardware e software. Desta forma, o sistema está preparado para ser atualizado para um ambiente multiusuário.

- Flexibilidade para mudanças ou atualizações na base de conhecimento ou no conjunto de procedimentos de treinamento, que podem estender a reusabilidade.

- Reusabilidade no sentido de que a flexibilidade a mudanças ou atualizações na base de conhecimento existente ou no conjunto de procedimentos de treinamento sejam vastos o suficiente para construir um STI completamente diferente. O conhecimento existente e armazenado no modelo KBES (Knowledge-based Expert System) pode ser modificado ou atualizado por um especialista em solda, ou de acordo com as atualizações do curso de treinamento a nível de arquivo de base de dados, sem a necessidade de alterar o código do WITS ou KBES. Isso permite que o WITS gere outros cursos de treinamento ou STIs que utilizem a mesma filosofia de treinamento.

Como já se sabe, uma das características mais importantes de um STI é proporcionar um treinamento adaptativo, ou seja, fornecer atividades e/ou instruções apropriadas ao nível de habilidade do usuário, à medida em que este acumula conhecimento e experiências ao longo da interação com o sistema. No WITS, esta característica foi implementada através de um "feedback loop" que seleciona os parâmetros das seções de treinamento de acordo com o desempenho do usuário nas seções anteriores. O desempenho pode ser definido baseado em erros, solicitação de ajuda ou tempo. As seções em que o usuário demonstra maiores dificuldades são reapresentadas mais tarde, com base nos parâmetros armazenados pelo sistema. O peso atribuído aos parâmetros determina o nível de sucesso em cada seção, e um conjunto desses pesos pode ser visto como o modelamento da filosofia individual de ensino de instruções.

\subsubsection{CALAT: STI para treinamento em Telecomunicações}

CALAT (Computer Aided Learning and Authoring Environment for Tele-Education) [Kiy97] é um sistema distribuído inteligente de instruções assistidas por computador baseado em web, desenvolvido para autoria de sistemas de treinamento na área de serviços de telecomunicações. Este sistema foi desenvolvido por uma equipe da divisão de treinamento da NTT Information and Communication Systems Laboratory, empresa japonesa prestadora de serviços neste segmento naquele país. Com um número enorme de funcionários, cujas funções vão desde o 
desenvolvimento técnico e manutenção de equipamentos, até serviços ao consumidor, entre muitas outras áreas, a empresa tem necessidade constante de estar treinando o seu pessoal. Este treinamento ocorre não somente quando há realocação ou contratação de pessoas, mas também quando ocorre introdução de novas tecnologias. Os exemplos mais recentes são os serviços relacionados à Internet e comunicação móvel. Devido à grande diferença no nível de habilidade desses funcionários, havia uma forte necessidade de um sistema de treinamento capaz de se adaptar a cada indivíduo.

Visando atender esta demanda por treinamento, o CALAT foi desenvolvido com a finalidade de permitir que pessoas especialistas na área a ser treinada, seja manutenção de equipamentos, vendas ou qualquer outra área, e que não sejam necessariamente profissionais em computação possam desenvolver sistemas de treinamento que proporcionem instruções de maneira adaptativa e individualizada aos seus usuários. Sua arquitetura é cliente-servidor, e os usuários com permissão para utilizar o sistema podem acessar esse servidor através de um browser de qualquer lugar do mundo, fornecendo sua própria identificação. Enquanto o usuário estiver logado, o servidor monitora a solicitação das páginas seguintes e os resultados dos exercícios, determina o próximo material a ser apresentado e envia as imagens de tela e informações de áudio para o terminal do usuário. Esta abordagem permite que os usuários tenham acesso a cada nova aplicação disponível, sem a necessidade de se atualizar os sistemas através de mídia.

O CALAT foi projetado para tirar vantagem das características de multimídia distribuída e hipertexto da www, e utiliza arquivos HTML para composição dos cenários, e figuras estáticas ou animadas em formato GIF, AVI ou MPEG2. Ao invés de oferecer ferramentas para criação de material multimídia, o sistema permite que o autor utilize qualquer ferramenta disponível para editoração multimídia. O mapeamento desse material aos cenários é feito através de URLs, o que significa que materiais existentes em outras partes pela Internet podem ser incorporados ao conteúdo do curso simplesmente ao se fornecer a URL. Como exemplos, destacamos sites de coleções de fotografias e enciclopédias. O CALAT pode também ser utilizado juntamente com e-mail ou telefone pela Internet, para permitir a comunicação entre os usuários e os instrutores humanos, e não somente o estudo individualizado.

Recentemente, o CALAT foi introduzindo como um dos meios de treinamento interno na NTT, onde basicamente os sistemas para treinamento são planejados e criados em diferentes organizações, tais como nos Institutos de Treinamento, nos Setores de Comunicações Regionais e na divisão de desenvolvimento de Recursos Humanos. Seus conteúdos incluem treinamentos básicos em telecomunicações, instalação e manutenção de switches e outros equipamentos, suporte a vendas, além de muitos outros.

Esses sistemas utilizados para treinamento interno são desenvolvidos sob as seguintes exigências:

- Criar aplicações adaptáveis aos indivíduos.

- Permitir a autoria de sistemas por especialistas na área a ser ensinada. 
- Possuir uma estrutura genérica que possa ampliar o seu uso para diversas áreas (técnica à prestação de serviços).

- Treinamento em procedimentos além do conhecimento intelectual.

- Facilidade de manutenção das aplicações.

\section{Arquitetura do CALAT}

O CALAT é composto de um modelo de conhecimento (modelo do domínio), que contém o conhecimento sistemático em um campo particular de aprendizado, de um modelo de conhecimento de estratégias de ensino (modelo tutorial) relacionado a como os instrutores proporcionam o aprendizado, e um modelo de informações do aluno (modelo do aluno), que mantém o acompanhamento da compreensão de cada aluno em relação ao material. Esta arquitetura difere da tradicional por não conter um modelo de interface, pois a apresentação de material é feita pelo próprio modelo de estratégias de ensino.

A arquitetura desse sistema é representada pela figura 5.1.

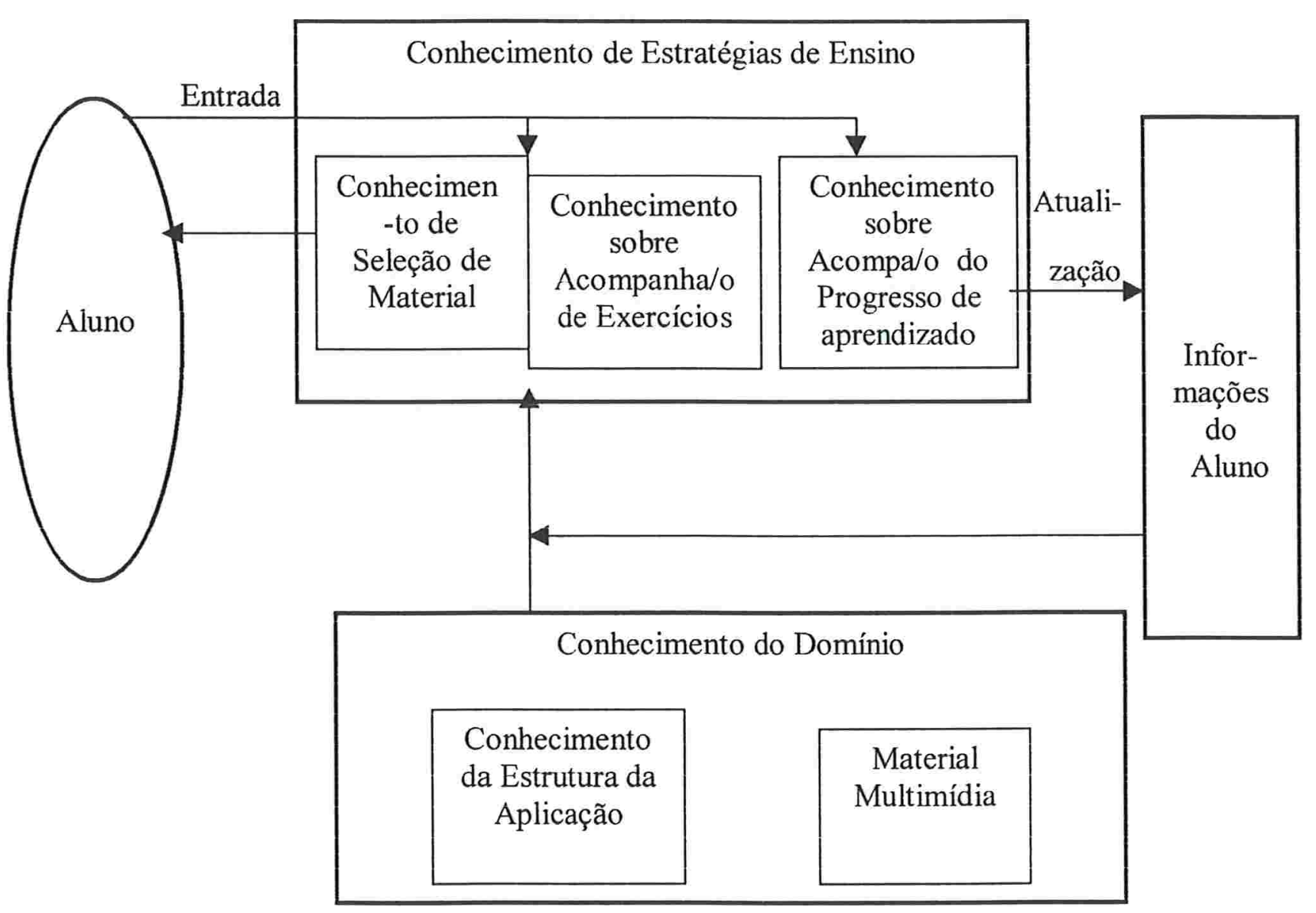

Fig. 5.1 - Arquitetura do CALAT 
O modelo de conhecimento do domínio consiste de material multimídia apresentado ao usuário como cenas, e de conhecimento da estrutura da aplicação, que descreve a sua estrutura lógica, e é composto por:

- Objetivos de aprendizado: relação do conhecimento a ser ensinado aos usuários. Uma vez que o assunto é definido, a relação deve ser praticamente a mesma, independente do autor do sistema.

- Cenário: define a estória da aplicação (o que será ensinado em que seqüência). Assemelha-se à estrutura de capítulos e páginas de um livro. Difere de uma aplicação para outra, mesmo que o assunto seja igual. No CALAT, os capítulos são denominados seções e as páginas correspondem a elementos.

- Mapeamento dos cenários aos objetivos de aprendizado: define a correspondência entre os objetivos de aprendizado, as seções c os elementos. Esta relação é n-n, já que um elemento pode ensinar dois ou mais objetivos de aprendizado e um objetivo de aprendizado pode corresponder a dois ou mais elementos (ensinados de maneira diferente). Essa relação pode ser definida entre cada pergunta em um exercício prático e os objetivos que ela cobre.

- Mapeamento dos cenários ao material multimídia: define as telas de informações apresentadas aos usuários em cada elemento do cenário. No CALAT, a relação com as telas de informações é especificada por URLs.

- Representação do conhecimento procedimental: representa o conhecimento procedimental em duas camadas: a camada de conhecimento alvo, consistindo somente de ações de simulação do equipamento, e a camada de conhecimento dos procedimentos de operação, descrevendo os procedimentos a serem ensinados.

O modelo do aluno adota o modelo de overlay, que representa o conhecimento do aluno como um subconjunto da base de conhecimento do sistema tutor.

O conhecimento de estratégias de ensino é composto por quatro tipos de conhecimento:

- Conhecimento de seleção de material: de acordo com a entrada do usuário, o material ótimo a ser apresentado em seguida é selecionado e apresentado, dependendo da informação do usuário.

- Conhecimento de acompanhamento de exercícios: as causas das respostas erradas de um aluno são analisadas para determinar qual o conteúdo não entendido. Dicas ótimas são selecionadas e apresentadas ao aluno.

- Conhecimento de acompanhamento do progresso do aprendizado: baseado na entrada do usuário (comandos de controle do aprendizado, respostas aos exercícios, etc.), o sucesso da compreensão do aluno e outros fatores específicos do aluno são estimados e refletidos na informação do aluno. 
- Conhecimentos de ensino de procedimentos: procedimentos de operação são ensinados através da simples apresentação de amostras, ajuda e aconselhamento com experiências práticas, utilizando uma abordagem tutorial.

\section{$\underline{\text { Sistema para autoria de Aplicacão }}$}

\section{Processo de criação de uma aplicação}

Como ferramenta para desenvolvimento de sistemas para treinamento, o CALAT permite a autoria de aplicações baseada em 4 passos principais, cada um dos quais consome um tempo estimado, nas seguintes proporções:

1. Planejamento da aplicação

2. Projeto da aplicação

3. Preparação de material multimídia

4. Testes e avaliações consumo de $10 \%$

consumo de $50 \%$

consumo de $30 \%$

consumo de $10 \%$

\section{Projeto do conhecimento da aplicação}

No sistema de autoria original do CALAT, todo o projeto da aplicação é feito no papel. Nesta fase, o autor passa por um processo repetitivo de julgamento e erro para refinar e desenvolver o conhecimento da aplicação. Como a entrada dos dados no sistema ocorre somente quando o projeto estiver pronto, o funcionamento da aplicação não pode ser verificado antes do estágio final de autoria.

Estes passos de projeto (entrada e teste em seqüência) constituem o método de desenvolvimento em cascata. Para superar as dificuldades características deste método, foram implementadas duas funções de suporte ao projeto. Suporte para edição de informações do projeto e geração automática de conhecimento da aplicação. Após criada a aplicação, são realizados os testes de checagem de consistência e adequabilidade do conteúdo. Uma vez testada, a aplicação pode ser transferida para o servidor do CALAT para ser utilizado para estudo.

Projetos futuros para o CALAT incluem planejar maneiras de reutilizar aplicações existentes e recursos na internet, e criar uma estrutura para evolução da aplicação. Segundo [Kiy99], atualmente o CALAT encontra-se comercialmente disponível ao custo de US $\$ 1.000,00$ e tem sido utilizado fora da NTT em várias empresas de telecomunicações, universidades e escolas. O sistema foi desenvolvido em Dephi e C++, porém o GUI possui versão somente em japonês, limitando em parte a sua utilização.

\subsubsection{Sistema LEAP}

O Shell LEAP (Learn, Explore and Practice) [BMDS96] já citado anteriormente, é uma plataforma para desenvolvimento de STIs baseados em tarefas, que foi desenvolvida por uma 
equipe em US West Advanced Technologies, no Colorado (EUA), composta por pessoas altamente qualificadas, todos especialistas em LISP. Seis dos oito integrantes tinham Ph.D., em áreas como Ciência da Computação, Psicologia Cognitiva, Lingüística e Antropologia.

O primeiro protótipo de LEAP foi criado em 1993 por uma equipe de 4 pessoas, dentre os quais estavam dois desenvolvedores, um SME e um gerente. Porém, em 94, o sistema foi reescrito e gerou uma versão beta mais robusta. Nesta fase, havia 4 desenvolvedores, 2 SMEs, um analista e várias outras pessoas associadas a teste de usabilidade, além de pessoal de suporte ao sistema. Nos anos de 94 e 95, o sistema foi utilizado por representantes de vendas para teste por tempo limitado, para se verificar a eficiência e viabilidade do sistema, e a essa altura, o LEAP já se mostrava bem sucedido, baseado nos níveis de desempenho dos usuários. Entretanto, os SMEs estavam tendo dificuldade em desenvolver e manter aplicativos e por isso, decidiram que uma ferramenta de autoria seria útil. Essa ferramenta foi projetada e desenvolvida em 95 .

A versão final de LEAP continha dois componentes semi-independentes: o "shellengine" e a base de conhecimento. O primeiro é especializado no sentido de proporcionar funcionalidade tutorial comum ao longo de um tipo de tarefa. O segundo é um componente do shell que é executado no "engine" (dispositivo). Este componente proporciona a funcionalidade específica de uma aplicação tutorial. Segundo Blumenthal [Blu99], o LEAP é composto pelos quatro modelos básicos de um STI, porém as ferramentas de autoria não podem ser classificadas da mesma maneira. Elas eram utilizadas na construção de gramáticas (diálogos de discurso) e de ações nos diálogos. Isso corresponde mais ao modelo do especialista. $\mathrm{O}$ modelo do aluno era deduzido a partir desta gramática durante o tempo de execução, porém, segundo o autor, o LEAP não fazia muita modelagem do aluno.

Um atributo considerável quando se trata de STIs é a sua reusabilidade. Na indústria, um argumento freqüente é o de que, devido ao alto custo no desenvolvimento de uma plataforma de STI, os desenvolvedores devem ser capazes de demonstrar o custo-benefício, seja na reutilização de toda plataforma ou de componentes do STI de uma aplicação para outra (e possivelmente até reutilização de partes de uma base de conhecimento entre aplicações).

O primeiro caso de reutilização é direcionado ao desenvolvimento de plataformas de STIs para domínios nos quais múltiplas aplicações podem facilitar tanto o desenvolvimento quanto a reutilização da base de conhecimento [Blo95].

O segundo caso de reutilização está relacionado a tirar o máximo proveito das arquiteturas e dos códigos dos STIs. Entretanto, no mínimo, ser genérico significa ser capaz de reutilizar o modelo do usuário, o modelo instrucional, e mecanismos de inferência da base de conhecimento de uma aplicação de treinamento para a outra.

O LEAP e suas ferramentas foram desenvolvidos para um domínio (habilidade de interação com consumidores) em que várias aplicações em treinamento podem ser geradas (algumas das quais permitem a reutilização de partes das bases de dados já existentes, assim como a reutilização completa da interface do usuário de uma aplicação para outra). 
Apesar do crescimento na oferta de serviços on-line, o papel dos Representantes de Serviços ao Consumidor (RSC) no atendimento a chamadas telefônicas continua sendo essencial em empresas comerciais. Um RSC deve ter habilidade para simultaneamente:

a) conversar com consumidores para resolver problemas e vender serviços

b) atender chamadas telefồnicas

c) dar entrada e acessar dados corretamente em um sistema e

d) entender as características, disponibilidade e serviços oferecidos pela empresa.

A aquisição destas e outras habilidades geralmente exigem uma quantidade considerável de treinamento formal e pelo menos um ano de experiência prática [BMDS96].

Além disso, essas aplicações vão além de uma única indústria: o LEAP pode ser utilizado para desenvolver aplicações para treinamento para representantes de serviços ao consumidor em hotel ou companhias aéreas, que também interagem com consumidores enquanto lidam com uma variedade de aplicações de software, com a mesma facilidade com que são desenvolvidas as aplicações voltadas para treinamento de representantes de serviços ao consumidor em telecomunicações para o qual ele foi projetado.

Os tutores LEAP proporcionam ambientes supervisionados onde os usuários sendo treinados podem interagir com consumidores e com sistemas de computador de maneira a praticar habilidades a serem utilizadas em ambientes de trabalho reais [BMDS96].

As primeiras aplicações do LEAP foram em domínios relacionados ao treinamento de RSC. Embora muitas outras aplicações tenham sido desenvolvidas, o LEAP não está mais disponivel como um sistema de trabalho. Segundo Blumenthal [Blu99], o LEAP foi desenvolvido em LISP para estações de trabalho UNIX, as quais tinham um custo muito elevado para a época em que o LEAP foi criado. No período em que a web estava se tornando aceitável, Blumenthal e Meiskey começaram a migrar o sistema para ambiente web utilizando Java (1997). Entretanto, um grande problema do LEAP era a necessidade de áudio duplex, pois o LEAP havia sido desenvolvido para permitir empregar reconhecimento de discurso e compreensão da linguagem natural. Porém, o discurso utilizado na aplicação era muito sofisticado para a tecnologia de reconhecimento tanto de discurso quanto de linguagem natural, ainda real nos dias de hoje.

O que o LEAP fazia era permitir que o usuário gravasse as respostas para determinadas perguntas ou situações. Em seguida, o sistema apresentava uma coleção de opções (caixas de seleção), para que o usuário selecionasse todas as opções abordadas na resposta oral. As respostas orais estavam gravadas e o usuário podia revisá-las. Estavam também disponíveis a um tutor humano. Os usuários podiam ainda ouvir suas respostas e compará-las às respostas de especialistas previamente gravadas. Estudos experimentais mostraram que os usuários tinham um melhor desempenho neste tipo de cenário.

Segundo [Spa99], o LEAP nunca foi amplamente disponibilizado como se pretendia originalmente, devido a uma série de motivos. Uma delas foi a mudança de prioridade na 
empresa: os orçamentos para treinamento foram reduzidos e o LEAP aparentava ser muito caro, embora estivesse apresentando bons resultados. O custo de se disponibilizar o LEAP também parecia muito alto, por ter sido desenvolvido antes da Internet/web tornar-se popular e reduzir os custos de treinamento baseado em web. O LEAP, como foi originalmente implementado, exigia hardware e software especiais. Havia planos de se reimplementar o LEAP como um sistema baseado em web a um custo mais reduzido, porém este projeto não foi realizado, embora haja eventual interesse de um dos autores em fazê-lo.

Apesar de todo esforço consumido pelo LEAP, aparentemente não há previsão de retomada dos trabalhos, já que a equipe em U S West se dispersou e não há mais pesquisas em STIs no instituto. Além disso, segundo Blumenthal [Blu99], a documentação e qualquer outro material sobre o sistema não está mais disponível, e restringe-se a materiais publicados e à memória dos autores.

\subsubsection{PROTTEL-D Projeto de Sistemas Tutoriais para Telefonia Digital}

O PROTTEL [Dir99] é um projeto em desenvolvimento na Universidade Federal do Paraná (UFPR) e financiado pelo Centro de Treinamento Werner von Siemens-Equitel Telecomunicações, e constitui um STI para operação e manutenção de centrais digitais de comutação telefônica. Este sistema denominado SATELIT é baseado em conceitos de visualização de cenários e de estudo de casos, e tem como objetivo principal proporcionar a aprendizes iniciantes o conhecimento tanto em forma de princípios como em forma de perícia em operação e manutenção das centrais digitais.

O treinamento é constituído de duas fases. Na primeira fase, a de operação e manutenção livre, o sistema ajuda o iniciante a explorar, observar e descobrir o comportamento dinâmico e individual de componentes e conceitos elementares da central de comutação, além de proporcionar experimentos com seqüências de comandos em uma máquina abstrata de operação e manutenção. Na segunda fase, a de operação e manutenção gerenciada, os iniciantes compõem e coordenam aglomerados de comandos, conceitos e construções linguísticas, observados e descobertos na primeira fase, para resolver problemas propostos, sob a supervisão inteligente do SATELIT. 


\section{Capítulo 6}

\section{Metodologias e Ferramentas para Desenvolvimento de STIs}

Os STIs têm se mostrado bastante promissores como ferramentas de ensino e treinamento em áreas como educação, indústria e empresas. Entretanto, ao longo da última década, alguns dos softwares tutoriais mostraram ser pouco mais que uma apresentação tela a tela de conteúdos com questões que, quando corretamente respondidas, faziam o usuário progredir para a próxima tela. Uma insatisfação comum era a incapacidade do sistema se adaptar às necessidades particulares de aprendizado do usuário [Ek194]. Progressos em ambientes de aprendizado inteligentes e softwares relacionados, dentre os quais estão os STIs, foram impedidos, dentre outros motivos, pela falta de sistemas de arquitetura modular, componentes reutilizáveis, bases de conhecimento compartilháveis e limitações de recursos de hardware e tecnologia.

Porém, nos últimos anos, algumas destas questões têm sido tratadas, na tentativa de desenvolver-se STIs cada vez mais eficientes. Embora ainda não exista um padrão que determine todos os requisitos que devem ser levados em conta ao desenvolver-se um STI, destacamos na seção 6.2. algumas considerações importantes que podem melhorar a qualidade e o desempenho de um STI. Em seguida, apresentaremos algumas questões sobre a avaliação de STIs.

\subsection{Limitações de hardware e tecnologia}

Se, há algum tempo atrás,o crescimento na área de STIs era dificultado por fatores como limitação de hardware e falta de tecnologia e recursos que permitissem criar aplicações mais ricas e mais fiéis ao modelo real (baseado no homem), hoje, pode-se dizer que esta barreira diminuiu. Segundo [Ek194], os avanços de harware no que se refere a capacidade de armazenamento em disco, disponibilidade de memória e recursos de gráfico e som, entre outros, têm permitido suportar sistemas mais poderosos. Dispositivos como o CD ROM 
permitem aos desenvolvedores codificarem rotinas mais complexas utilizando esta mídia mais interativa. A multimídia tem aumentado a flexibilidade do aprendizado baseado em computador, através da sua habilidade para reestruturar as apresentações de conhecimento, de forma a adequarem-se às situações variáveis. Essas novas características dos computadores tornaram-se disponiveis há um curto espaço de tempo, e o hardware continua a se desenvolver de maneira surpreendente. Baseado nessas condições, prevê-se que a capacidade dos softwares tutorias, em breve, irão proporcionar um discurso muito mais natural entre o usuário e o sistema, se comparado aos padrões atuais. Embora esses recursos sejam essenciais à eficiência e à qualidade dos STIs, o sucesso dos sistemas consiste na habilidade para comparar os processos cognitivos do aluno, registrando a sua aquisição de conhecimento, e na habilidade para apresentar as lições de maneira estimulante e interativa.

Uma das limitações é a incapacidade de se dotar os sistemas de recursos sensitivos como olfato, tato e visão. Segundo [Gir97], um instrutor humano pode e leva estes estímulos em consideração para poder organizar seu trabalho junto ao aluno, e utiliza as saídas destes sentidos para fins de feedback. A compreensão de como o cérebro humano efetivamente processa as informações ainda é desconhecida, ou seja, não se tem uma resposta sobre como as informações são armazenadas, processadas e recuperadas no cérebro, e como isso é trabalhado na mente humana. Questões como essas são essenciais para a construção de um modelo fiel do aluno e, portanto, extremamente importante para a construção de um STI. Porém, esta questão permanecerá em aberto, até que surjam alternativas de modelagem e implementação.

\subsection{Considerações ao se desenvolver STIIs}

Para que os STIs sejam amplamente utilizados, deveria ser fácil desenvolver um STI eficiente para o ensino ou treinamento. A construção de um tutor de qualquer nível razoável de sofisticação normalmente requer o esforço de uma equipe de desenvolvimento ao invés de um esforço individual [Mur96]. Para tanto, deve-se considerar questões como usabilidade, independência de domínio, múltiplas estratégias de ensino, modelamento do aluno, reusabilidade e interoperabilidade, da forma como estão relacionados aos STIs [Hsi95] [Kem95].

\subsubsection{Usabilidade}

Um sistema que apresenta usabilidade é aquele que pode ser usado pelo grupo a quem ele foi projetado, sem necessitar de habilidade ou treinamento. Uma ferramenta de desenvolvimento de STI usável deve ser acessível a alunos, instrutores e desenvolvedores.

É comum encontrarmos sistemas simples que podem ser facilmente entendidos por não especialistas em computadores, porém com eficiência muito limitada para produzir sistemas educacionais úteis. Por outro lado, encontramos também sistemas altamente sofisticados, porém de compreensão complexa para professores e especialistas, em relação às técnicas de desenvolvimento sendo utilizadas, dificultando o completo envolvimento em todos os estágios do processo de desenvolvimento [Kem95]. 
No caso de alunos, usabilidade significa:

- interface instantaneamente compreensível;

- o sistema deve operar de forma que as opções mais úteis em qualquer ponto estejam evidentes ao aluno.

No caso de desenvolvedores, usabilidade significa que o sistema deve livrá-los o máximo possível de tarefas nas quais eles não têm experiência, como por exemplo, conhecimentos didáticos ou recursos para modelagem de interface.

Uma maneira de aumentar a usabilidade para desenvolvedores de instruções é deixar o projeto de instruções e o conhecimento de programação nas mãos do sistema, para que o desenvolvedor possa se concentrar em descrever o conhecimento a ser ensinado. Outra maneira de aumentar a usabilidade é proporcionar uma interface familiar ao desenvolvedor, utilizando termos relacionados à sua área.

Finalmente, um sistema apresenta usabilidade quando pode ser executado em equipamentos facilmente disponíveis.

\subsubsection{Independência de Domínio}

Devido à diversidade na definição de domínio (vista na seção 2.4.1.), segundo [NSB91], independência de domínio pode ter várias interpretações. No caso de estratégias instrutivas independentes do domínio, o significado pode ser o de estratégias que são independentes do tema (por exemplo, estratégias diferentes da matemática), ou independentes do resultado do desempenho (isto é, estratégias apropriadas tanto para o aprendizado do conceito quanto para a resolução de problemas). Em outras palavras, o problema da independência de domínio é um problema de grau de transferência ou generalização.

Independência de domínio, segundo [Hsi95], refere-se à capacidade do STI suportar múltiplos domínios. Porém, este é um objetivo difícil de se alcançar, devido ao fato de que o produto final não é uma coleção de apresentações, mas sim uma representação do conhecimento, e domínios diferentes representam o conhecimento de maneira diferente. É difícil projetar uma ferramenta para desenvolvimento de STIs que possa acomodar tanto o conhecimento de uma variedade de domínios, quanto manter profundo conhecimento sobre um determinado domínio. Uma ferramenta de desenvolvimento de STIs verdadeiramente independente de domínio pode ser impossivel de se obter. Kemp acredita que o melhor que se pode alcançar é que, para tipos específicos de habilidades e, possivelmente, tipos específicos de métodos de ensino, ferramentas apropriadas podem ser construídas.

\subsubsection{Múltiplas Estratégias de Ensino}

Segundo [Hsi95], alguns pesquisadores têm sugerido que diferentes alunos têm diferentes necessidades em termos de métodos de ensino: aprendizado por descoberta, apresentações, etc, e alguns alunos podem precisar trocar de um método para outro. 
Múltiplas estratégias de ensino proporcionam ao aluno várias maneiras de ver e aprender o conteúdo do material do domínio sendo ensinado, permitindo uma compreensão mais profunda do material.

Diferentes estratégias de ensino são necessárias a fim de assegurar performance adequada em diferentes situações com diferentes exigências sobre o aluno.

COCA, RAPITS [WW95], [WW96], DOMINIE [Eklb] e MOBIT [LBSM95] são exemplos de sistemas que possuem múltiplas estratégias de ensino. Mais detalhes sobre cada sistema podem ser encontrados nas referências citadas acima.

Apesar dos sistemas atualmente buscarem oferecer múltiplas estratégias de ensino na tentativa de se assemelharem cada vez mais aos instrutores humanos, segundo Kemp, é difícil proporcionar muitas estratégias diferentes no mesmo ambiente.

\subsubsection{Reusabilidade}

A reutilização de software [AECF96] [Kar95] é definida como o processo de se criar novas aplicações utilizando softwares previamente desenvolvidos, ao invés de construí-los a partir do zero. A reusabilidade é uma característica importante de um componente de software de alta qualidade, e nos dias de hoje, a visão de reuso foi ampliada a fim de envolver não somente algoritmos, mas também estruturas de dados [Press95]. Em analogia ao processo de desenvolvimento de software, a produção de sistemas de ensino/treinamento pode ser aperfeiçoada através da reutilização dos resultados de projetos anteriores [SM95]. A reutilização pode se referir a material de aprendizado em multimídia não produzido especificamente para o sistema em desenvolvimento, por exemplo (som, gráficos, fragmentos de textos), ou então englobar a reutilização de partes de produtos das fases de projeto do sistema, tais como fragmentos de representação do domínio, componentes do modelo de aprendizado, etc. O principal objetivo desta técnica é melhorar tanto a qualidade quanto a produtividade do software [Kar95].

De um modo geral, a reusabilidade pode ser decomposta em duas atividades [Kar95]:

I) Desenvolvimento para reuso e

II) Desenvolvimento $\underline{c o m}$ reuso.

I) O desenvolvimento para reuso consiste em uma atividade planejada, na qual partes de software são preparadas para que possam ser utilizadas em outros contextos. Essas partes reusáveis são denominadas componentes reusáveis, e podem ser qualquer parte de um software. Além disso, não estão restritos a nenhuma granularidade particular ou fase de ciclo de vida (a granularidade dos componentes pode ser classificada em granularidade fina ou granularidade grossa. Componentes de granularidade fina são geralmente genéricos e independentes de domínio. Fazem parte desta categoria componentes como funções de entrada/saída, funções de acesso a bases de dados e arquivos, funções de manipulação de estruturas de dados e classes individuais de objetos. Componentes de granularidade grossa 
podem ser subsistemas de aplicação tais como servidores de bases de dados, pacotes de interface com o usuário, etc.). $\mathrm{O}$ desenvolvimento para reuso estende $\mathrm{o}$ processo de desenvolvimento para as seguintes atividades:

- Analisar a variabilidade nas exigências entre diferentes reutilizadores dos componentes.

- Analisar os custos e benefícios da incorporação destas exigências.

- Projetar os componentes com o nível apropriado de generalidade para todos os reutilizadores.

Além disso, o desenvolvimento para reuso inclui atividades de reengenharia de componentes existentes, qualificação e classificação dos componentes, a fim de que estejam prontos para serem reutilizados.

II) O desenvolvimento com reuso consiste na construção de novos softwares a partir de componentes reutilizáveis. Este processo inclui as seguintes atividades:

- Buscar um conjunto de componentes candidatos.

- Avaliar os componentes a fim de obter o mais apropriado.

- Se necessário, adaptar o componente selecionado para que satisfaça as exigências.

O maior motivo pelo qual se leva em consideração questões sobre a reusabilidade na área de STIs é devido ao fato de que a construção de STIs requer ambientes de desenvolvimento razoavelmente grandes. Algumas ferramentas exigem enormes recursos computacionais e são lentos e inviáveis para o desenvolvimento tanto de protótipos experimentais para finalidades de pesquisa, quanto de sistemas práticos de ensinoaprendizagem. Além disso, estes ambientes são caros e dificilmente comportados em computadores pessoais. Levando-se em consideração que os sistemas são construídos incrementalmente através de acréscimos e refinamentos sucessivos, o tempo e o custo de desenvolvimento é largamente reduzido com a reutilização de softwares previamente desenvolvidos.

A reusabilidade pode ser considerada também em relação ao conhecimento de ensino, porém encontra dificuldades devido à falta de uma linguagem padrão para representar o conhecimento, de uma interface padrão para permitir que as aplicações acessem o conhecimento, e de um conjunto de ferramentas para permitir que os projetistas manipulem o conhecimento [Jon95].

Para que a reusabilidade seja eficiente, o material a ser reutilizado deve ser fácil de acessar, modificar e integrar em contextos diferentes dos originais. Caso contrário, o custo de reutilização pode ser mais alto que o custo de desenvolver a partir do zero. Tornar o material facilmente acessível é a primeira consideração necessária para se obter reusabilidade. 
A base para se gerar softwares de STIs reutilizáveis é mantida pelo projeto modular de seus componentes. $\mathrm{O}$ projeto modular permite não somente a reusabilidade como também o compartilhamento e a transportabilidade. Compartilhamento no sentido de que o mesmo conhecimento possa ser utilizado por vários sistemas implementados em diversas linguagens de programação; transportabilidade no sentido de que o mesmo conhecimento possa ser instalado em plataformas diferentes.

\subsubsection{Regras de Reusabilidade}

Sarti e Marcke [SM] definiram reusabilidade da seguinte maneira:

\section{Reusabilidade $=$ restauração + adaptabilidade}

Restauração pode ser obtida através do projeto e desenvolvimento de uma gama de material que é disponibilizado a desenvolvedores. Tanto os autores do material quanto outros autores em potencial devem ser providos de facilidades de consulta, a fim de encontrarem o material que satisfaz os requerimentos exigidos.

Esta definição deu origem a regras de reusabilidade que embora pareçam óbvias e simples, são difíceis de satisfazer na prática.

Restauração: para selecionar um componente a ser reutilizado, é preciso saber primeiro o que ele faz; para reutilizá-lo eficientemente, deve ser possivel identificá-lo mais rápido do que se fossemos construí-lo.

Adaptabilidade: para que uma técnica de reutilização seja eficiente, ela deve reduzir a distância cognitiva entre o conceito inicial do sistema de treinamento e sua implementação final executável; além disso, deve ser mais fácil reutilizar os componentes ao invés de desenvolvê-los a partir do zero.

\section{Destaques para Reusabilidade}

Seleção: A necessidade por restauração requer que os autores sejam capazes de selecionar, entre um conjunto de componentes reutilizáveis possíveis, aquele que melhor atende às suas necessidades.

Abstração: Suporta tanto a restauração quanto a adaptabilidade.

Especialização: Uma vez que o componente foi identificado e selecionado, ele deve ser adaptado ao novo contexto.

Integração: A integração é necessária para se obter adaptabilidade. Um componente reutilizável pode, na verdade, ser considerado como um módulo oferecendo serviços, provido de uma interface específica. A atividade de integração consiste em implementar no sistema o protocolo que controla o componente, interagindo com ele através da interface. 


\subsubsection{Interoperabilidade}

A incapacidade da maioria dos softwares de aplicação educacional em compartilhar dados padronizados com software de múltiplos fornecedores e em trabalharem juntos para realizarem objetivos em conjunto tem gerado discussões sobre a questão da compatibilidade. Na área da computação, essa compatibilidade entre múltiplos fornecedores é geralmente denominada interoperabilidade [Row95].

Aspectos como a interoperabilidade e a reusabilidade têm contribuído para aumentar a eficiência dos ambientes baseados em computador em diversos domínios, e mostram-se promissores no aumento de eficiência nas pesquisas e no desenvolvimento de STIs. Segundo Rowley [Row96], a interoperabilidade é muito além de uma simples abordagem para se obter melhor custo-benefício e reusabilidade. A interoperabilidade facilita a criação de sistemas de grande porte através da definição dos requisitos para transações de interação entre muitos sistemas menores.

À medida em que a interoperabilidade tem se tornado uma questão mais ampla na área da computação, é importante se considerar exemplos onde a interoperabilidade é bem sucedida [Row95]. O exemplo mais comum é o da Internet. Neste caso, vários softwares cooperam para gerenciar múltiplas unidades de redes eletrônicas, cada uma conectada a uma espinha dorsal eletrônica comum. Enquanto cada um dos softwares envolvidos em uma única transação na Internet pode ser sustentado por diferentes plataformas de hardware e fornecedores de sistemas de telecomunicações, cada transação ocorre de maneira confiável ao longo das várias redes. A interoperabilidade entre os componentes da Internet permite a criação de uma enorme infra-estrutura de telecomunicação, facilitando a proliferação de aplicações em áreas globais, tais como flp e www.

Outro exemplo bem sucedido quanto à interoperabilidade é o padrão MIDI (Musical Instrument Digital Interface). Este padrão, comumente encontrado em casa, nas escolas e em estúdios de som profissionais, foi desenvolvido por um consórcio de fornecedores de equipamentos musicais eletrônicos, e foi designado para permitir a todas as marcas de instrumentos musicais eletrônicos computadorizados utilizarem uma interface comum tanto em nível de hardware quanto de software.

Baseados nesses exemplos bem sucedidos, considerações sobre padrões de interoperabilidade e reusabilidade para pesquisas e desenvolvimento de STIs podem influenciar os resultados de instruções baseadas em STIs.

Pesquisadores e desenvolvedores devem considerar uma visão das possibilidades, os níveis nos quais os padrões de interoperabilidade podem ser aplicados [Row96], possíveis componentes de STIs interoperáveis e requisitos para a implementação de padrões de interoperabilidade e reusabilidade entre STIs. Esses padrões podem proporcionar vantagens como:

- Permitir que os STIs tirem proveito de produtos comerciais compatíveis.

- Aumentar o custo-beneficio e a reusabilidade dos componentes de STIs em diversos domínios. 
- Aumentar o nível de interação entre STIs relacionados.

Apesar dos benefícios que poderiam ser obtidos ao se considerar a interoperabilidade e a reusabilidade em STIS (aumento na eficiência dos STIs e ampliação da disponibilidade dos tutores construídos a partir de componentes interoperacionais e reutilizáveis), esses benefícios somente serão verificados quando as especificações técnicas necessárias forem aplicadas e sustentadas por pesquisadores e desenvolvedores de STIs.

Um ambiente ideal de pesquisa e desenvolvimento de STIs interoperacionais seria aquele que oferecesse [Row96]:

- Possibilidade de criar STIs personalizados a partir de componentes interoperacionais e reutilizáveis.

- Um padrão para definir um conjunto de protocolos de interface para módulos de sistemas de autoria de STIs, permitindo que o desenvolvedor misture e combine componentes.

- Flexibilidade para que cada módulo do sistema interoperacional possa ser criado por um desenvolvedor ou laboratório de pesquisa diferente, cada qual seguindo padrões de interface para comunicação entre módulos e de estruturação do conteúdo e bases de dados de conhecimento para ser utilizado entre todos os componentes interoperacionais do STI.

- Possibilidade dos módulos componentes de um STI não estarem limitados a conteúdos específicos.

- Possibilidade de desenvolver um STI distribuído que utilizasse recursos da Internet (seleção e recuperação automática de recursos de aprendizado interoperacionais para ser utilizado por um STI central).

Esta abordagem de interoperabilidade para STIs requer um alto nivel de flexibilidade ao projetar os módulos do sistema. Exige também cooperação entre pesquisadores e desenvolvedores, além de compartilhamento de informações em alto nível, o que permitirá que muitos modelos de STIs possam interagir e trabalhar juntos a fim de alcançar objetivos maiores. Assim, seria possível criar-se novos STIs com mais rapidez e os STIs interoperacionais poderiam suprir necessidades, onde quer que elas ocorressem, através de STIs globalmente distribuídos. 


\subsection{Metodologias para o Desenvolvimento de STIs}

\subsubsection{Metodologia de construção a partir do zero}

Segundo [JK96], a metodologia mais comum de desenvolvimento de sistemas tutores em geral requer dos projetistas que cada nova pesquisa ou desenvolvimento comece tipicamente do zero, no pior caso, ou a partir de módulos de componentes básicos, no melhor caso. A metodologia de construção a partir do zero implícita nas ferramentas existentes faz sentido a partir da perspectiva de se criar uma ferramenta em que se possa desenvolver uma grande variedade de sistemas tutores. Entretanto, esta metodologia também sofre de inúmeros problemas sérios que afetam o custo, a qualidade, a manutenção e a reusabilidade de sistemas tutores baseados em computador. Por isso, STIs têm tradicionalmente sido sistemas de grande escala que são caros para produzir e difíceis para adaptar a objetivos curriculares diferentes aos do projeto original. Estas circunstâncias são indesejáveis e inaceitáveis, já que os custos elevados continuam a impedir a integração bem sucedida de aplicações destes sistemas nos mundos corporativos e educacionais.

\section{Problemas com a metodologia de desenvolvimento a partir do zero}

Ferramentas de desenvolvimento para STIs que requerem que o desenvolvedor monte uma nova aplicação tutorial a partir de módulos de componentes básicos ou a partir do zero falham ao apresentar três sérios problemas:

- Projetar é difícil: o esforço de se projetar sistemas tutoriais motivadores e pedagógicos é extremamente difícil, mesmo para projetistas experientes. A maioria das ferramentas de desenvolvimento não ajudam em nada nesses casos. Espera-se que o projetista tenha se preocupado com o quê e como ensinar antes de utilizar as ferramentas. Algumas perguntas que o projetista deve fazer incluem: Quais serão os objetivos de ensino do sistema? Quais elementos de uma matéria em particular a ser ensinada serão incluídas e quais deixadas de lado? Como será estruturada a tarefa do usuário de modo a alcançar estes objetivos?

- Implementar é difícil: sistemas tutores baseados em computador tendem a ser sistemas grandes e complexos, e como tais, enfrentam as mesmas questões que qualquer outro sistema de computador de grande porte. Dependendo da sofisticação das ferramentas sendo utilizadas, o projetista deve ainda programar e integrar os vários módulos do sistema tutor. Mesmo que alguns módulos previamente construídos estejam disponíveis, eles ainda deverão ser integrados com o resto do sistema. Além disso, a interface do usuário deve ser implementada geralmente do zero. Tudo isso é acrescentado a um processo difícil que leva tempo e está fora do alcance de professores e outros profissionais da área sem experiência em programação.

- A qualidade e a consistência dos aplicativos resultantes varia muito: uma conseqüência dos dois problemas anteriores é que sistemas tutores criados por ferramentas de desenvolvimento a partir do zero existentes nem sempre são da 
melhor qualidade. Isto ocorre particularmente em ferramentas comerciais de desenvolvimento disponíveis, mas mesmo ferramentas avançadas desenvolvidas em laboratórios de pesquisa sofrem da mesma crítica. Certamente, profissionais altamente treinados, constantemente apoiados por programadores profissionais, podem e fazem uso destas ferramentas avançadas para criar sistemas tutores de alta qualidade. Entretanto, uma vez que estas ferramentas deixam o laboratório e são colocadas nas mãos de profissionais menos bem treinados, os sistemas tutores produzidos podem ser de qualidade inferior e de mérito pedagógico duvidoso. Além de outros problemas, isto acaba dando à área de sistemas tutores baseados em computador um nome ruim.

\subsubsection{Metodologias Alternativas para Desenvolvimento de STIs}

\subsubsection{A metodologia SAND}

Uma metodologia alternativa para desenvolver sistemas tutores baseados em computador consiste em criar uma arquitetura de ensino completamente projetada e implementada. Uma arquitetura de ensino, no sentido utilizado aqui, significa um sistema que inclua:

- uma tarefa para o usuário executar e uma simulação ou outro ambiente na qual deve desempenhar essa tarefa;

- uma representação da tarefa do usuário que o sistema possa utilizar e entender o que ele estiver fazendo;

- um conjunto de estratégias ou intervenções de ensinamento ligadas à tarefa do usuário; e

- uma interface do usuário que permita que ele possa se engajar na tarefa, acessar qualquer recurso de informação que seja exigida durante a tarefa e receber orientação.

Em outras palavras, a arquitetura é um sistema tutor completo, mas um na qual todas as peculiaridades do domínio a ser ensinado são isoladas e daí podem ser substituídas pelo conteúdo de outro domínio. Esta metodologia conhecida como SAND (Same Architecture New Domain, ou Mesma Arquitetura Novo Domínio) foi utilizada por Bell, Kedar, Korcuska e seus colegas no desenvolvimento do sistema Sickle Cell Counselor e outros sistemas com a arquitetura de ensinamento "Investigar e Decidir" no Institute for the Learning Sciences Uma segunda arquitetura de ensinamento utilizando a metodologia SAND foi patrocinada pelo programa ARPA Computer Aided Education and Training Initiative (CAETI). Esta arquitetura é chamado de Advise (Aconselhar)[JK96].

\section{Vantagens da metodologia SAND}

A metodologia SAND tem várias vantagens sobre a metodologia de construção a partir do zero implícita na maioria das ferramentas de desenvolvimento. 
- O projeto de sistema e da interface já foi trabalhado. Isto permite que o projetista se concentre no conteúdo daquilo a ser ensinado, não na interface ou na implementação que tipicamente tomam a maior parte do tempo do esforço total.

- Pelo fato da arquitetura ser fixa, é possível criar-se ferramentas de desenvolvimento ricas em conhecimento que possam assistir ativamente o projetista em "instanciar" a arquitetura com o novo conteúdo do domínio. Em outras palavras, as ferramentas de desenvolvimento são capazes de conhecer as contingências no projeto e o papel de cada elemento do conteúdo no sistema. Isto significa que as ferramentas de desenvolvimento podem ordenar apropriadamente a tarefa de desenvolvimento, requerendo do projetista o conteúdo do domínio de um modo metódico e eficiente. Durante o processo de desenvolvimento, ferramentas ricas em conhecimento como estas podem também explicar ao projetista para quê serve um dado elemento do conteúdo e por quê é necessário. E mais, ferramentas "front-end" também podem ser criadas para ajudar o projetista a analisar e estruturar seus objetivos de ensinamento e conteúdo de domínio antes de utilizar a ferramenta de desenvolvimento principal para entrar com o conteúdo no sistema. Daí, ferramentas de desenvolvimento ricas em conhecimento podem ser criadas para assistir o projetista através do processo tanto da implementação como do design do conteúdo.

- Questões de implementação são simplificadas. Devido ao fato das ferramentas SAND serem sistemas tutores completos e funcionando, pouca ou nenhuma programação é exigida. O custo total da implementação é concentrado na construção da arquitetura original. Não há necessidade de integrar componentes ou módulos. Lidar com questões como otimizar a performance em tempo de execução e diminuir o sistema para se adequar a exigências de memória reduzida são uma parte difícil, idiosincrática e freqüentemente mundana, mas necessária a fim de entregar um sistema tutor real e que funcione. Em aplicativos SAND, o engine de tempo de execução é pré-testado, debugado e otimizado. Programadores habilidosos já se preocuparam em como fazê-lo funcionar em plataformas de distribuição de baixo nível, evitando que tais questões preocupem o projetista.

É claro que a metodologia SAND tem limitações. A mais óbvia é que cada ferramenta SAND para o qual ele é mais apropriado tem um alcance de domínios mais limitado na construção de sistemas tutores baseados em computador. De um modo geral, a metodologia de construção a partir do zero implícita na maioria das ferramentas de desenvolvimento existentes falham ao lidar com muitas questões sérias. Por outro lado, a metodologia SAND, lidando com essas questões, fornece uma alternativa viável para a criação de sistemas tutores reutilizáveis de alta qualidade.

\subsubsection{Prototipação}

Embora [Kem95] afirme que a criação de um protótipo não seja o melhor método para o desenvolvimento de STIs, é baseada nesta abordagem da engenharia de software que a maioria dos STIs são construídos. 
A prototipação, segundo [Press95], é um processo que capacita o desenvolvedor a criar um modelo de software que será implementado, ou seja, uma versão inicial de um sistema, que ocorre geralmente durante a especificação de requisitos. O modelo pode assumir uma das três formas:

1. um protótipo em papel ou modelo baseado em PC que retrata a interação homemmáquina de uma forma que capacita o usuário a entender quanta interação ocorrerá;

2. um protótipo de trabalho que implementa algum subconjunto da função exigida do software desejado ou

3. um programa existente que executa parte ou toda a função desejada, mas que tem outras características que serão melhoradas em um novo esforço de desenvolvimento.

A prototipação inicia-se com a coleta dos requisitos, onde são definidos os objetivos globais para o software c as exigências conhecidas. Ocorre então a claboração de um "projeto rápido", representando os aspectos do software que serão visíveis ao usuário. O projeto rápido leva à construção de um protótipo que é avaliado pelo cliente/usuário, e é usado para refinar os requisitos para o software a ser desenvolvido.

\subsubsection{Incorporando Tutores Inteligentes em Pacotes de Software Pré-existentes}

A incorporação de agentes tutores em softwares pré-existentes proporciona a criação de ferramentas de trabalho e ambientes de aprendizado mais poderosos. Exemplos destes sistemas estão em [RK96] e a arquitetura foi descrita na seção 3.2.3. Agentes tutores foram incorporados ao software "Geometer's Sketchpad", utilizado para a criação de construções geométricas, e ao ambiente "Resolução de Problemas de Álgebra Utilizando Microsoft Excel", com a finalidade de permitir que o sistema forneça ajuda ao usuário quando requisitado. Para isso, a opção "TUTOR" foi incluída no menu e foi criada uma janela no ambiente de trabalho utilizada pelo tutor para fornecer dicas e dar feedback.

\section{Elementos Básicos de um Ambiente de Aprendizado}

Uma consideração importante em um ambiente de aprendizado é certificar-se de que o mesmo está ciente do objetivo do usuário ao executar alguma ação. Existem alguns sistemas como o "Tip Wizard" do Microsoft Excel 5.0, que monitoram a seqüencia de ações do usuário e o informa sobre atalhos. Por exemplo, tal sistema poderia detectar que um usuário passou por várias caixas de diálogo para executar uma ação, quando a mesma poderia ser executada pressionando uma tecla de função. Estes sistemas são limitados a dar conselhos sobre a manipulação da interface, já que não possuem conhecimento prévio dos objetivos do usuário, e não é aceitável esperar que se seja capaz de descobrir tais objetivos observando as ações do usuário em um ambiente complexo.

Nos sistemas tutores citados acima um problema é apresentado ao usuário, e este problema se torna a meta de mais alto nível. Uma vez conhecidos os objetivos do usuário, é possível direcionar a assistência de maneira a atingir esses objetivos dentro do ambiente, 
independente do modo como sejam feitos. Um ambiente específico pode ou não comentar ações do usuário que são irrelevantes e que estão em conflito com o objetivo.

Este ambiente de desenvolvimento contém quatro objetos, os quais foram descritos na seção 3.2.3: uma Ferramenta, um Agente Tutor, um Tradutor e um Gerenciador de Currículo. Os sistemas gerados a partir desta abordagem, segundo [RK96], combinam os melhores elementos das ferramentas de trabalho e dos ambientes educacionais, com instruções guiadas que demonstraram ser eficientes.

De acordo com [Koe99], os sistemas descritos não estão disponíveis e avaliações formais sobre os sistemas não foram realizadas. Porém, informalmente, estima-se que para um tutor de geometria criado anteriormente, foram consumidas 200 horas de desenvolvimento para uma hora de instrução. Embora os avanços na tecnologia tenham chegado ao ponto onde é prático se considerar o desenvolvimento de sistemas através deste método, alguns padrões ainda precisam ser determinados a fim de generalizar o tipo de interação para um ampla variedade de domínios.

\subsection{Ferramentas e Shells para Desenvolvimento de STIs}

Ao mesmo tempo em que os tutores inteligentes estão se tornando mais comuns e têm se mostrado cada vez mais eficientes, eles ainda são caros e difíceis de se desenvolver. Sistemas de autoria estão disponíveis comercialmente para instruções assistidas por computador tradicionais (IAC), porém esses sistemas não apresentam a sofisticação necessária para construir tutores inteligentes. Do mesmo modo, os sistema comerciais para autoria de sistemas multimídia oferecem ao desenvolvedor de instruções as ferramentas para produzir telas interativas e visualmente atraentes, porém atrás das telas estão representações pedagógicas e de conteúdo superficiais [Mur99].

Um modo razoável de reduzir custos de desenvolvimento é através da utilização de ferramentas ou shells especializados para construção de STIs [BMDS96]. Os pesquisadores têm estudado ferramentas para autoria de STIs praticamente desde o início das pesquisas em STIs [Mur99]. O desenvolvimento destas ferramentas é a principal preocupação quando se considera a aplicabilidade de STIs a uma larga extensão de domínios. A generalidade de tais ferramentas pode variar enormemente. A ferramenta pode ser bem genérica ou pode restringir os STIs resultantes a um domínio em particular (por exemplo, eletrônicos) ou a um tipo específico de tarefa (por exemplo, conversar com outra pessoa no telefone.)

Embora um nível alto de generalidade possa parecer desejável, uma ferramenta bem implementada pode ser extremamente difícil de se obter. Tentar fazer uma ferramenta com alto nível de generalidade leva a STIs pedagogicamente fracos ou que exijam esforço de desenvolvimento não muito inferior aos STIs individualmente construídos [BMDS96].

Um boa oportunidade para se entender as dificuldades associadas com ferramentas de STIs muito genéricas pode ser vista na história das ferramentas de finalidade genérica de sistemas especialistas (SE). O desenvolvimento de ferramentas de SE mais antigos seguiram a filosofia "mais é melhor" e incorporaram muitas características dentro de uma ferramenta. 
Esta abordagem permite que ela atenda às necessidades de mais usuários, mas freqüentemente às custas de um usuário em particular. Nas ferramentas de SE mais recentes, muitas dessas características foram julgadas desnecessárias e removidas. Esta evidência sugere que pode não ser aconselhável construir ferramentas para STI de propósito geral, "tamanho-único serve para todos", e sim, concentrar-se em ferramentas com características gerais para um domínio específico ou tipo de tarefa.

Sobre as ferramentas que restringem o tipo de STI que podem produzir, um tipo de restrição é a área do domínio dentro da qual o STI pode ser desenvolvido. Por exemplo, uma ferramenta pode incluir muitos domínios de conhecimento sobre eletrônica e permitir que projetistas e instrutores desenvolvam uma variedade de STIs dentro do domínio. Os sistemas resultantes podem variar de acordo com a idade e o passado dos usuários-alvo e também de acordo com o tipo de ambiente de desenvolvimento que melhor sirva para os aspectos particulares do referido domínio.

Outro modo de utilizar as limitações na generalidade de uma ferramenta para STI (para produzir sistemas resultantes de qualidade superior) é restringir não a área de domínio mas o tipo de tarefa cuja execução é solicitada ao usuário. Por exemplo, o sistema LEAP [BMDS96] pode ser utilizado para produzir vários STIs, mas cada um será centralizado na tarefa do usuário conversando com outra pessoa pelo telefone. $O$ usuário pode ser alguém treinando para ser um representante de vendas, serviços, um agente de viagens ou especialista em recursos humanos.

Aplicativos de atendimento ao cliente e de agentes de viagem são exemplos de tutores específicos que podem ser construídos através da reutilização de componentes modulares. Um aspecto importante de uma ferramenta para desenvolvimento de STI será a facilidade com que permitirá que profissionais na área (usuários não tecnicamente treinados) desenvolvam rápida e facilmente novos aplicativos.

Segundo [Mur99], basicamente, os esforços no desenvolvimento de ferramentas de autoria de STIs até os dias de hoje representam muitas abordagens diversificadas, e é cedo ainda para se ter uma idéia de qual abordagem se mostrará mais útil ou mais facilmente vendida. De maneira geral, ferramentas para autoria de STIs são ainda objetos de pesquisa que têm tido sucesso significativo em casos limitados, embora ainda não sejam robustos o suficiente para serem colocados e sustentados em produção ou no mercado. Entretanto, é animador o fato de que alguns sistemas tenham sido lançados como produtos ou estão próximos disto.

Ao se classificar o recurso sendo utilizado no desenvolvimento de um tutor inteligente, podemos distinguir as ferramentas e os shells. É comum utilizarmos o termo ferramenta quando nos referimos ao recurso utilizado para autoria de um STI. Porém, existem os shells, que, segundo [Mur99], são estruturas generalizadas para a construção de STIs, ao passo que um sistema de autoria ou ferramenta de autoria é um shell juntamente com uma interface para o usuário, que permite que não programadores possam formalizar e visualizar seu conhecimento. Uma das maiores diferenças entre as ferramentas é o grau em que seus modelos restringem o produto, onde os sistemas classificados como sendo de finalidade específica são 
os mais restritos. Apesar desta diferenciação, é comum encontrarmos os dois termos sendo utilizados para se definir o mesmo recurso.

\subsubsection{Vantagens da utilização de ferramentas}

De maneira geral, podemos enumerar alguns motivos que justificam a utilização de ferramentas para o desenvolvimento de STIs, embora não haja uma rigorosa ordem de importância ou predominância [Mur99].

1. Redução de esforços na construção de STIs (tempo, custo e/ou outros recursos).

2. Redução na exigência de habilidade para construção de tutores inteligentes, permitindo que mais pessoas possam participar do processo de criação.

3. Ajudar o projetista/autor a articular ou organizar o conhecimento do domínio ou pedagógico.

4. Sustentar (ou seja, estruturar, recomendar ou impor) bons princípios de projeto (em pedagogia, na interface do usuário, etc).

5. Permitir prototipação rápida de tutores inteligentes, ou seja, permitir ciclos mais rápidos de criação e avaliação de protótipos de softwares.

\subsubsection{O Shell RIDES}

O RIDES (Rapid Intelligent Tutoring System Development Shell) [FH96] é projetado para ambientes de treinamento onde a interação do usuário com modelos gráficos (baseados em computador) de dispositivos ou domínios complexos pode significativamente melhorar o aprendizado. Desenvolvedores de instruções e profissionais no assunto interagem com uma simulação do RIDES para criar sistemas de treinamento adaptados que possam ser utilizados em computadores pessoais de mesa comuns. Um aspecto importante do RIDES é o fornecimento de métodos pelos quais 1) uma instrução pode ser gerada automaticamente quando o instrutor interage com uma simulação e 2) essa instrução pode então ser passada de tal forma que o tutor possa determinar como responder a alunos individuais, baseado na sua interação com a simulação e nos objetivos do curso como definidos pelo desenvolvedor de instruções. As simulações no RIDES são baseadas em componentes de dispositivos (e propriedades) e suas conexões.

Utilizando um conjunto de editores integrados no ambiente RIDES, o desenvolvimento do tutor começa com a criação de "objetos" de simulação e seus comportamentos. O RIDES suporta a criação de modelos gráficos interativos pela manipulação direta. O comportamento do modelo é definido por atributos intrínsecos cujos valores podem ser determinados utilizando uma linguagem de alto nível em expressões de regra relacional ou declarações dirigidos-por-evento. Um dispositivo (engine) de simulação gerencia a ativação destas expressões em resposta a ações de alunos. 
O modelo gráfico interativo criado é então utilizado como o contexto para a instrução pela criação de "unidades de conhecimento" que contêm informações sobre o domínio modelado, e a construção de "unidades de instrução" que exploram o conhecimento e o modelo criado. Ferramentas de criação de instrução suportam uma variedade ampla de atividades de aprendizagem (e.g. nomenclatura, identificação de componentes de sistema e relações entre componentes, operações, procedimentos, interpretação de indicadores do sistema e diagnóstico de falhas). Desenvolvedores de instruções podem criar uma variedade de exercícios pedagógicos baseados em modelos fornecidos pelo editor de exercício padronizado ou podem ter mais controle específico das instruções geradas utilizando o editor de unidade de instrução. Em ambos os níveis, o RIDES, monitorando diretamente interações com o modelo criado, melhora a produtividade da criação de instruções.

Um tutor RIDES completo consiste de um conjunto de objetivos de aprendizagem que devem ser cumpridos pelo usuário. Cada objetivo é associado com uma lição e pode exigir diferentes níveis de interação e/ou respostas do usuário. Enquanto o aluno progride com o tutor, o RIDES mantém um modelo do conhecimento do usuário, baseado nos objetivos do curso. Decisões sobre quais lições a serem apresentadas a seguir são controladas pelas relações entre os objetivos do curso e o estado do modelo do usuário. Se as estações de trabalho dos usuários estão em um ambiente de rede, o RIDES pode relatar o progresso do usuário através do programa de console do instrutor (RADMIN). Os instrutores podem observar quais usuários estão participando da instrução, o objetivo específico do curso de interesse do usuário e o tempo gasto para alcançar o objetivo.

\subsection{3 "Intelligent Tutor": Shell, Toolkit \& Technology}

O "Intelligent Tutor" (Shell, Toolkit \& Technology) [Good96] possui arquitetura modular genérica baseada na teoria de controle fuzzy, contém módulos reutilizáveis, utiliza planejamento dinâmico de diálogo tutorial, pode utilizar materiais tutoriais prontos e suporta fácil desenvolvimento e manutenção de aplicativos baratos em muitas disciplinas diferentes.

O "Intelligent Tutor" inclui Shell, Toolkit, módulos aplicativos e manuais da Tecnologia para o desenvolvimento de módulos aplicativos. O Shell consiste de módulos reutilizáveis e pode ser preenchido por materiais tutores prontos para criar um novo módulo aplicativo. O Toolkit é utilizado para facilitar o desenvolvimento de módulos aplicativos de acordo com a Tecnologia proposta.

STIs (ou módulos aplicativos) desenvolvidos nesta base são capazes de realizar planejamento dinâmico de diálogo tutorial e tutoriar de modo adaptativo. Eles permitem aos alunos escolherem (e mudarem em qualquer passo):

- as origens da aprendizagem;

- os objetivos da aprendizagem;

- um modo de funcionamento do módulo aplicativo. 
Este sistema contém todos os módulos típicos de outros STIs, mas em favor da simplicidade, os seguintes melhoramentos chaves acrescentam:

- a ausência do solucionador de problema (sistema especialista) no domínio sob estudo;

- utilização de material tutorial pré-armazenado sem a sua geração automática;

- uma extensão de uma camada Student Model tradicional com Modelo de Distribuição de Conhecimento, Modelo de Origem de Conhecimento e Modelo de Manifestação de Conhecimento.

Este modelos adicionais são declarativos e fáceis de construir por profissionais dentro de um tema concreto. Livram profissionais do projeto de procedimentos difíceis propensos a erros, planos ou regras de funções de STIs. Isto torna-se possível porque o Sistema pode dinamicamente planejar e executar automaticamente.

\subsubsection{Ferramentas com Finalidade Específica}

Ferramentas que prezam a generalização têm o poder de suportar o desenvolvimento de uma variedade de aplicações. No entanto, ferramentas de finalidade genérica geralmente impõem limitações no modo de interação nas aplicações, oferecem pouco suporte ao desenvolvimento e contam com modelos genéricos de instrução. Além disso, exigem uma enorme extensão de conhecimento para suportar o desenvolvimento.

Uma forma alternativa de superar isso é através da criação de ferramentas de finalidade específica ao invés de genérica, que devem ser construídas sobre um modelo definido de instrução. Uma ferramenta deste tipo deve ser capaz de suportar uma rica interação e ser capaz de proporcionar melhor orientação durante o desenvolvimento. Assim, uma ferramenta específica pode ser menos flexível permitindo desenvolver um número mais reduzido de aplicações, porém mais poderosa no seu escopo limitado.

A ferramenta GBS Builder (Goal Based Scenario Builder), para construção de cenários baseados em objetivos, permite criar ambientes onde se aprende fazendo (técnica de learning by doing, apresentada em [Sch97]). Esta ferramenta é baseada na subclasse Investigar \& Decidir dos Cenários Baseados em Objetivos. A ferramenta conta tanto com um modelo abstrato, quanto com um exemplo: o Sickle Cell Conselor, desenvolvido por Bell, Bareiss \& Beckwith. Além disso, guia o projetista durante o processo de instanciar cada fase do modelo.

Apesar das vantagens de ferramentas específicas, tais como a facilidade na codificação do conhecimento, a interface mais específica de acordo com a tarefa, entre outros, ferramentas muito específicas podem perder a sua utilidade. Uma tendência parece ser permitir que as ferramentas genéricas ofereçam meios de proporcionar formas de customização com mínimo esforço. Assim, inicialmente o GBS Builder tinha a finalidade de ser uma ferramenta específica, porém com a necessidade de se incluir conhecimento além do que foi representado no modelo inicial, foi desenvolvido o IMAP. Sua finalidade é personalizar o GBS Builder para utilizar em domínios de experimento em laboratório. Os esforços em se construir ferramentas 
genéricas continuarão, enquanto aquelas mais específicas servirão para personalizar as genéricas.

\subsubsection{TRAINER: o Sistema Baseado em Casos}

TRAINER é uma ferramenta flexível para desenvolvimento de STIs baseado na poderosa ferramenta D3, que permite classificações baseadas em casos e estatísticas, entre outros. Além disso, possui bases de conhecimento para domínios médicos, como reumatologia e neurologia, assim como para problemas técnicos como diagnóstico de erros em impressão de jornais. Em [RS91], é apresentado o sistema TRAINER com uma base de conhecimento de reumatologia.

Este sistema é bastante flexível no que diz respeito a superar um dos maiores problemas encontrados na construção de ferramentas para STIs: encontrar uma maneira para suportar mais de um domínio, sendo que domínios diferentes usam métodos de ensino e utilização de lingüística diferentes, dificultando a decisão sobre como a interface dos STIs deve parecer. A flexibilidade se deve ao fato de que existe um diálogo de configuração que permite levar em consideração a interface e a estratégia de ensino.

Uma das principais decisões é em relação ao nível de interação entre o sistema e o aluno. No TRAINER, existem duas maneiras de conduzir o aluno através do caso. Primeiro, o especialista pode dividir os sintomas em grupos numa base de conhecimento médico (histórico, exames e testes técnicos de laboratório). Cada grupo é apresentado seqüencialmente pelo sistema, e em cada um deles o aluno deve selecionar um diagnóstico. A outra maneira é apresentar alguns sintomas inicias e deixar o aluno decidir quais exames fazer no paciente, podendo o sistema criticar tanto o exame quanto o motivo apresentado pelo aluno. Desta maneira, os alunos podem aprender tanto a interpretar textos quanto a selecionar testes.

\subsubsection{Ferramentas Baseados em Hipermídia}

Peter Brusilovsky e o seu grupo do Moscow State University and International Center for Scientific and Technical Information têm estudado, durante anos, o problema de se criar ambientes de aprendizado inteligentes integrados. De acordo com a experiência acumulada nesse tempo, propôs o que, segundo ele, representa uma maneira natural e confiável de se desenvolver ferramentas para construção de STIs.

1. Projetar um certo número de Ambientes de Aprendizado por Instrução baseados no mesmo conceito, permitindo identificar quais fases são semelhantes para os diferentes sistemas.

2. Separar componentes reutilizáveis das partes dependentes do domínio, gerando um kit de ferramentas para uso interno com a finalidade de facilitar o desenvolvimento de novos sistemas.

3. Desenvolver ferramentas de criação que utilizem o kit de ferramentas. 
A partir deste ponto, a tecnologia pode ser considerada um produto, e pode ser denominada "ferramenta", por permitir a utilização por pessoas externas ao grupo de desenvolvimento.

Baseados nesses passos, sistemas como o ITEM/IP [Bru95], ISIS e ITEM/PG foram desenvolvidos pelo grupo, integrando componentes hipermídia por todo o ambiente.

Um recurso que tem sido muito utilizado com a finalidade de ser fonte de aquisição de conhecimento conceitual é a WWW. Uma ferramenta para desenvolvimento baseado em hipermídia na WWW foi proposta por Brusilovsky em [BSW96]. Na maioria dos casos, a WWW é utilizada como uma ferramenta de suporte ao aprendizado para cursos a distância quando um professor qualificado não está disponível. Como resultado o sistema deve ser completo e auto-suficiente, ou seja, tem que suportar a aquisição tanto do conhecimento procedural como do conceitual.

A hipermídia provou ser uma boa ferramenta para suportar a aquisição de conhecimento conceitual. É também o paradigma principal para a estruturação de conteúdo na WWW. Neste sentido, um STI baseado em hipermídia que seja uma integração de um STI ou AAI com um material de curso estruturado em hipermídia fornece um bom modelo para projetar um STI auto-suficiente para a WWW. Peter Brusilovsky, Elmar Schwarz e Gerhard Weber desenvolveram uma ferramenta que simplifica o processo de criação de componentes hipermídia para STIs na WWW [BSW96]. Esta ferramenta ajuda o autor de um STI baseado em LISP a transferir um livro texto normal existente em forma eletrônica em um livro texto parte de um componente hipermídia de um STI. Além disso, proporciona o máximo de suporte para os autores no desenvolvimento dos componentes. Entretanto, como a ferramenta não é um sistema, pode ser utilizada com flexibilidade em contextos com alguma diferença. Assim, uma das características notáveis é a reusabilidade, já que a ferramenta não está relacionada a nenhum STI específico.

Além das ferramentas e sistemas desenvolvidos pelo grupo de Brusilovsky, existem vários outros com aplicações diversas, dentre os quais podemos destacar o sistema CALAT, desenvolvido com a finalidade de permitir o treinamento de funcionários da NTT, empresa japonesa que presta serviços na área de telecomunicações. Devido à frequêencia no treinamento de pessoal, seja por motivos de novas contratações, ou pela chegada de novas tecnologias, verificou-se a necessidade de se poder contar com um treinamento adaptável de acordo com as habilidades dos funcionários, através de um sistema que ofereça facilidade de se criar novos treinamentos, não necessariamente por profissionais de computação [Kiy97].

Embora possamos verificar inúmeras outras tentativas de se desenvolver ferramentas para construção de STIs ao longo da última década, como por exemplo: IDE, ID Expert, COCA, GTE, RIDES, citados em [Mur96], a maioria deles não saiu dos laboratórios ou não se viu muito uso em múltiplos domínios. Alguns dos motivos podem ser:

1. O fato desses sistemas serem baseados em instruções de abordagem específica.

2. Os domínios de aplicação serem limitados, devido aos sistemas terem sido modelados a partir de um tutor inteligente construído para uma tarefa específica, e generalizado para domínios semelhantes. 
3. Os sistemas serem muito complexos por basearem-se principalmente em aspectos teóricos ou em técnicas de IA.

4. Proporcionarem ferramentas para estruturar e utilizar o conhecimento, mas não para criar interfaces ou ambientes de aprendizado atraentes aos usuários. De um modo geral, embora algumas ferramentas sejam poderosas e genéricas, a maioria não aborda os aspectos práticos encontrados quando educadores realmente utilizam esses sistemas. O COCA é uma exceção, pois passou por testes de usuários.

\subsection{Avaliação}

\subsubsection{Medidas de Software}

Segundo [Press95], métricas de software referem-se a uma ampla variedade de medidas de software de computador, e dentro do contexto de gerenciamento de projetos de software, as medidas de produtividade e de qualidade são determinantes. citar:

Existem inúmeras razões pelas quais um software é medido, dentre as quais podemos

1. Indicar a qualidade do produto.

2. Avaliar a produtividade das pessoas que desenvolvem o produto.

3. Avaliar os benefícios (em termos de produtividade e qualidade) derivados de novos métodos e ferramentas.

Medidas diretas determinadas pelo custo e pelos esforços aplicados na construção de um software são relativamente fáceis de se obter, porém as medidas indiretas que incluem funcionalidade, qualidade, eficiência e capacidade de manutenção, dentre outras, são mais dificeis de serem avaliadas.

A qualidade pode ser medida ao longo do processo de desenvolvimento do sistema, de maneira a oferecer uma base quantitativa para se tomar decisões referentes ao projeto e aos testes, ou então pode ser medida após a finalização do sistema, proporcionando uma indicação da efetividade do mesmo.

\subsubsection{Avaliação de Sistemas Tutores Inteligentes}

À medida em que questões sobre STIs são pesquisadas e novos sistemas são desenvolvidos, considerações sobre metodologias de avaliação têm ganho maior importância [Mark91]. Pesquisadores, desenvolvedores de sistemas e educadores trabalhando com STIs têm sido envolvidos em avaliações de STIs.

Mark [Mark91] propõe dois métodos de avaliação: 
- Avaliação formativa, onde os pesquisadores examinam o sistema em desenvolvimento, a fim de identificar problemas e orientar modificações.

- Avaliação a posteriori, que tem a finalidade de considerar reclamações relacionadas à construção, comportamento ou resultados associados ao sistema finalizado.

Um método semelhante à avaliação formativa é também abordada por [Kem], segundo o qual a avaliação deve ocorrer durante os estágios iniciais do desenvolvimento do sistema, a fim de verificar se o esquema é viável e também para determinar quais as prováveis reações dos usuários. Embora a criação de protótipos seja muito comum quando se trata de STIs, [Kem95] afirma que este não é o melhor método, uma vez que os protótipos podem não possuir algumas características chaves do sistema final, tornando impossivel a avaliação exata.

Diferentes metodologias são apropriadas para diferentes tipos de avaliações, algumas focando em considerações internas, como arquitetura e comportamento, e outras focando em considerações externas, como o impacto educacional [Mark91].

Segundo [Kem95], testar qualquer esquema educacional é problemático. Ultimamente, o fator mais importante tem sido a melhora no desempenho do aluno como resultado da utilização do esquema. [Maj95] afirma que a grande maioria das avaliações de STIs têm sido baseadas na satisfação do usuário, seja ele um professor ou um aluno. Essas avaliações que têm demonstrado duros fatos sobre a performance dos STIs têm considerado experimentos controlados e têm medido o sucesso em termos da melhora no desempenho do aluno. Porém, [Kem95] aponta uma certa dificuldade no processo de avaliação, já que aspectos como entusiasmo, efeito da novidade, compromisso e conhecimento do professor, experiência do aluno, etc não devem ser considerados. Além disso, deve-se definir como qualquer melhora no desempenho deve ser medida.

A incorporação de IA em tutores ou em qualquer outro domínio tem a finalidade de fazer com que o computador faça algo de maneira inteligente [Lin95]. Os pesquisadores em tutores consideram-se bem sucedidos, então, se seus programas tornam o computador inteligente de alguma maneira que possa ser útil para o ensino e o aprendizado.

Quando pesquisadores de instruções (ou de tutores) aplicam inteligência computacional ao tutor, seus resultados são medidos em termos de aprendizado do aluno. Seu padrão de sucesso é que alunos aprendam melhor do que quando a partir de processos alternativos de instrução [Lin95].

Para se avaliar teorias de instrução e descobrir se professores ou pesquisadores (neste caso, quais pesquisadores) são realmente os especialistas em educação, o desempenho do aluno deve ser utilizado em condições experimentais. $\mathrm{Na}$ indústria, uma boa medida é determinar quanto tempo o usuário leva para aprender um certo conteúdo, se comparado ao treinamento normal. Este tipo de medida tem relação direta com o custo de treinamento e permite verificar se o sistema está se pagando. 


\section{Avaliação de Ferramentas}

Entretanto, na avaliação das ferramentas para desenvolvimento de STIs, existem outras medidas a serem consideradas. De acordo com [Maj95], em sérias avaliações de ferramentas de autoria e shells de STIs, o desempenho do aluno deve ser utilizado como uma medida, o que não somente permitirá comparar os sistemas, mas também comparar a IA com outros métodos de ensino. Além disso, a satisfação do professor é muito importante nesta avaliação, assim como o tempo de uma tarefa. Esta razão entre tempo de autoria e tempo de instrução tem sido utilizada para avaliação do processo de instrução. [Murb98] propõe ainda algumas outras medidas apropriadas para determinar o sucesso de uma ferramenta:

- Diversidade (em termos de área do domínio e/ou estilos de ensino) de STIs que uma ferramenta permite construir.

- Viabilidade econômica da utilização das ferramentas para construção de STIs.

- Profundidade ou sofisticação dos STIs criados através das ferramentas.

- Facilidade com que as ferramentas podem ser utilizadas.

Embora estas medidas representem uma forma de determinar o sucesso dos STIs, ainda é cedo para se avaliar a eficiência global das ferramentas de desenvolvimento, já que a maioria dos dados atuais relacionados a essas medidas são limitadas ou informais.

O surgimento de novas ferramentas, de modo geral, contribuem para diminuir o tempo e os esforços exigidos no desenvolvimento de novos sistemas, o que conseqüentemente leva à redução de custos e proporciona maior facilidade na criação de aplicações, se comparados aos STIs construídos a partir do zero. Essas vantagens contam favoravelmente ao sistema no momento de uma avaliação.

Algumas medidas finais de flexibilidade são ainda propostas por [Maj95]. Segundo o autor, estas medidas poderiam verificar qual extensão de comportamentos de ensino poderia ser implementada. Uma lista de conferência contendo estratégias padrões poderia ser construída, e cada sistema de autoria ou shell poderia indicar sua habilidade para implementar uma certa porcentagem dessas estratégias.

Embora medidas de avaliação diferentes tenham sido propostas por diversos autores, de uma maneira geral, não é comum encontrarmos informações sobre avaliação dos STIs disponíveis. Sistemas como o LEAP [BMDS96], por exemplo, não foram formalmente avaliados devido ao fato do sistema não ter sido disponibilizado amplamente, limitando-se à versão inicial que foi descontinuada. Muitos outros sistemas acabam seguindo este caminho, e desta forma, freqüentemente se verifica a ausência de qualquer tipo de avaliação, principalmente no caso de protótipos.

Por outro lado, quando a avaliação ocorre, a falta de um modelo que determine um padrão com os parâmetros necessários para a avaliação tanto das ferramentas de desenvolvimento quanto dos sistemas construídos a partir delas, acaba por limitar os dados da avaliação (quando ela ocorre) ao modelo determinado pelo autor de cada sistema. Isto acaba 
inviabilizando a comparação entre o desempenho de diferentes sistemas, embora não impeça a verificação da eficiência de cada sistema isoladamente. Dentre os sistemas estudados, o CALAT demonstrou possuir o maior número de aplicações desenvolvidas e ainda em uso, provavelmente devido a sua disponibilidade comercial, aliado ao fato de que a sua utilização como ferramenta de treinamento dentro da própria NTT demonstrou sua eficiência nas diversas aplicações. A avaliação apresentada em [Kiy97] baseia-se na análise do desempenho dos usuários do sistema em relação ao tempo consumido no processo de aprendizagem.

Como pudemos observar, os métodos de avaliação propostos ainda divergem quanto à forma de analisar a eficiência e o desempenho dos STIs e suas ferramentas de desenvolvimento. Embora tenhamos relacionado os pontos que consideramos importantes para a avaliação, podemos assumir que nas condições atuais, qualquer método pode ser considerado eficiente, desde que seu resultado comprove a real eficiência de um sistema, de acordo com os objetivos a que ele se propõe a atingir e de acordo com os usuários a que ele se destina. De uma certa forma, o resultado deste tipo de avaliação pode até justificar os investimentos financeiros envolvidos no desenvolvimento de um STI, comprovando o retorno deste mesmo investimento.

Espera-se que o crescimento na área de STIs leve à determinação de padrões e métodos de avaliação, à medida em que novos sistemas forem surgindo e cada vez mais dados sobre performance estiverem disponíveis, a fim de contribuir para o estabelecimento dos meios mais eficientes de avaliação. 


\section{Capítulo 7}

\section{Conclusão}

Os Sistemas Tutores Inteligentes surgiram como forma de superar as limitações dos sistemas tradicionais de ensino, mostrando-se capazes de interagir com o usuário e se adaptar às suas necessidades. Desta forma, têm demonstrado serem cada vez mais eficientes em ambientes onde algum conhecimento, habilidade ou experiência precisa ser adquirido. $\mathrm{O}$ crescimento nesta área se deve, em grande parte, à disponibilidade de recursos como hipermídia, multimídia e hardware mais acessíveis, que tem viabilizado a criação de aplicações mais completas, permitindo que os sistemas se assemelhem cada vez mais aos instrutores humanos na forma como conduzem o ensino. Os inúmeros STIs destinados ao ensino acadêmico e os mais recentes voltados ao treinamento de funcionários em empresas, principalmente em ambientes simulados, comprovam que há demanda por este tipo de instrução baseada em computador, como forma de adquirir o conhecimento e as habilidades necessárias.

Neste trabalho, apresentamos uma abordagem geral da área de STIs a partir da sua origem e sua evolução pela incorporação de técnicas de Inteligência Artificial e de Sistemas Especialistas. Exemplificamos a sua utilização em ambientes acadêmicos, enumerando alguns sistemas. Apresentamos também a arquitetura básica de um STI e algumas variações na arquitetura, geralmente determinadas pela incorporação de recursos como multimídia e hipermídia, entre outros. Sendo o nosso enfoque voltado para aplicações em empresas, realizamos um estudo da área de treinamento de uma maneira geral, a partir do qual observamos a importância que tem sido atribuída ao treinamento tanto por parte de funcionários, que buscam uma maior capacitação profissional, quanto por parte de empresas, que visam adquirir vantagens competitivas. Isto justifica os recursos financeiros que têm sido investidos nesta área, demonstrando que há cada vez mais espaço para os STIs.

Embora não sejam muitos os sistemas disponiveis para treinamento em empresas, apresentamos alguns deles e identificamos as suas áreas de aplicação. Metodologias e aspectos que determinam a melhor maneira de se construir STIs ainda estão em estudo, porém, 
reunimos neste trabalho alguns dos que consideramos ser importantes para viabilizar a construção de sistemas mais eficientes, a custos mais reduzidos e com consumo menor de tempo de desenvolvimento, contribuindo para o avanço da área.

O objetivo principal desta dissertação foi apresentar um estudo dos STIs e identificar ferramentas de desenvolvimento para aplicações em empresas, assim como apresentar sistemas implantados para fins de treinamento, alguns dos quais encontram-se em uso atualmente. Além disso, procuramos determinar os aspectos importantes que devem ser considerados ao desenvolver-se STIs ou ferramentas de desenvolvimento. Apresentamos algumas medidas que permitem avaliar seus desempenhos, com o intuito de comprovar a eficiência quanto à finalidade a que se destinam, e assim, justificar os esforços dispensados no seu desenvolvimento.

\subsection{Considerações Finais}

Ao longo das nossas pesquisas, buscamos aprofundar-nos nos estudos sobre as aplicações de STIs em empresas, uma vez que identificamos uma demanda por meios mais eficientes de treinamento de pessoal, comparados aos recursos utilizados atualmente.

Nos Estados Unidos e no Japão, pudemos verificar casos bem sucedidos de utilização de STIs para treinamento, alguns dos quais apresentaram projetos bem documentados. No Brasil, porém, podemos considerar que as pesquisas sobre aplicações nesta área encontram-se no início, uma vez que STIs voltados para treinamento não são facilmente encontrados. Durante o desenvolvimento deste trabalho, a nossa distância em relação aos grandes centros de pesquisas em STIs dificultou o nosso acesso a materiais mais específicos e, embora tenhamos tentado contato com diversos autores e empresas com trabalhos relacionados aos STIs neste meio, obtivemos pouco retorno.

Porém, pudemos constatar que apesar da cultura de incorporação de sistemas baseados em computador para fins de treinamento ser ainda pouco difundida, o sucesso da utilização dos STIs no meio acadêmico comprova a eficiência destes sistemas como ferramenta de ensino e abre o caminho para a sua entrada nos meios corporativos. Embora esta entrada esteja ocorrendo lentamente, acreditamos que os STIs serão uma grande promessa também como ferramentas de treinamento. 


\section{Bibliografia}

[AECF96] - A. Arruarte, J. A. Elorriaga, I. Fernández-Castro, B. Ferrero. Knowledge Reusability: Some Experiences in Intelligent Tutoring System. Position Paper for ITS '96 Workshop on Architectures and Methods for Designing Cost-Effective and Reusable ITSs, Montreal, June $10^{\text {th }} 1996$. http://advlearn.lrdc.pitt.edu/its-arch/papers/arruarte.html

[AR94] - Ana Cláudia Noivo Arantes e Solange Rezende Rodrigues. Um Sistema Tutorial para ambiente que auxilia a construção de núcleos específicos de sistemas especialistas (ANSEsp) - Versão 1.0. Número 19, Relatórios Técnicos do Instituto de Ciências Matemáticas de São Carlos. Junho, 1994.

[BAH97] - Booz-Allen \& Hamilton. Booz-Allen Awarded a \$25-Million Intelligent Tutoring System Contract, 1997. http://www.bah.com/press/inteltutor.html

[Blo95] - Charles P. Bloom. Roadblocks to Successful ITS Authoring in Industry. http://www.pitt.edu/ al/aied/bloom.html

[Blu99] - Richard Blumenthal. Manuscrito: mensagens eletrônicas recebidas em outubro de 1999.

[BMDS96] - Richard Blumenthal, Lori Meiskey, Scott Dooley and Randall Sparks. Reducing Development Costs with Intelligent Tutoring System Shells. Position Paper for ITS '96 Workshop on Architectures and Methods for Designing Cost-Effective and Reusable ITSs, Montreal, June $10^{\text {th }}$ 1996. http://advlearn.Irdc.pitt.edu/its-arch/papers/blumenthal.html

[Bru95] - Peter Brusilovsky. Integrating Hypermedia and Intelligent Tutoring Technologies: From Systems to Authoring Tools. http://www.pitt.edu/ al/aied/brusilov.html 
[BSW96] - Peter Brusilovsky, Elmar Schwarz, and Gerhard Weber. A Tool for Developing Hipermedia-Based ITS on WWW. Position Paper for ITS '96 Workshop on Architectures and Methods for Designing Cost-Effective and Reusable ITSs, Montreal, June $10^{\text {th }} 1996$.

[Ca199] - Solange Calvo. O funcionário é a prioridade. Network Computing Brasil. No.8, pages 20-22, outubro de 1999.

[CGVD97] - Cristina Conati, Abigail S. Gertner, Kurt VanLehn and Marek J. Drudzel. OnLine Student Modeling for Coached Problem Solving Using Bayesian Networks, 1997.

[CV96] - Cristina Conati, Hurt VanLehn. POLA: A Student Modeling Framework for Probabilistic On-Line Assessment of Problem Solving Performance.

http://www.pitt.edu/ vanlehn/distrib/UM96-abstract.html

[Dir99] - Alexandre Direne. PROTTEL-D PROjeto de sistemas Tutoriais para TELefonia Digital. http://www.inf.ufpr.br/ alexd/

[Ek194] - John H. Eklund. Cognitive Modeling in Intelligent Tutoring: Individualising Tutorial Dialog. School of Educational Psychology, Measurement \& Technology. Faculty of Education - University of Sydney $2006 . \quad \mathrm{http}: / / \mathrm{mac}-$ 30.aded.uts.edu.au/staff/john_eklund/isr.html

[Eklb] - John H. Eklund. Adaptive Learning Environments: The Future for Tutorial Software? Faculty of Education - University of Sydney 2006.

http://nabil.vuse.vanderbilt.edu/Adaptive_Learning.htm

[FH96] - Jimmy L. leming and Carol Horowitz. Applications of the Rapid Intelligent Tutoring System Development Shell (RIDES). Position Paper for ITS '96 Workshop on Architectures and Methods for Designing Cost-Effective and Reusable ITSs, Montreal, June $10^{\text {th }} 1996$. http://advlearn.Irdc.pitt.edu/its-arch/papers/fleming.html

[Fin91] - Pamela K. Fink. The Tole of Domain Knowledge in the Design of na Intelligent Tutoring system. In Intelligent Tutoring Systems - Evolutions in Design. Lawrence Erlbaum Associates, Publishers, pages 195-224, 1991.

[For84] - Richard Forsyth. Expert Systems. Principles and case studies.. Chapman and Hall Computing, 1984. 
[FPL87] - Nelson L. Duarte Filho, Tarcísio H. Pequeno, J. Cabral Melo Lima. Uma Técnica de Modelagem do Estudante para Uso em Programs Educativos Inteligentes. Anais $-4^{\circ}$ Simpósio Brasileiro de Inteligência Artificial, 1987.

[GH97] - Meike Gonschorek and Christian Herzog. Research Group Informatics I Programming, distributed programming. InTuSys Project Description, 1997. http://www.informatik.tu-muenchem.de/projekte/intusys/intusys_eng.html

[Gir97] - Lucia Maria Martins Giraffa. Seleção e adoção de Estratégias de Ensino em Sistemas Tutores Inteligentes. Exame de Qualificação. 1997.

[Good96] - Vladimir A. Goodkovsky. "Intelligent Tutor": Shell, Toolkit \& Technology. Position Paper for ITS '96 Workshop on Architectures and Methods for Designing CostEffective and Reusable ITSs, Montreal, June $10^{\text {th }} 1996$.

[Hsi95] - Patricia Yee Hsieh. Workshop: Authoring Shells for Intelligent Tutoring Systems. http://www.pitt.edu/ al/aied/hsieh.html

[ITSa96] - Intelligent Tutoring Systems (ITSs) [Expert Model] [Student Model] [Instructional Model] [ITS Feedback Formats] [Application] [References]

-- http://www.ott.sc.ist.ucf.edu/1_2/1_2_1/

[ITSb96] - Intelligent TutoringSystems (obtido através de busca no Altavista) http://lexus.gslis.utexas.edu/ palmquis/courses/project/txtifits.html

[ITSc96] - An Overview of Intelligent Tutoring Systems - Intelligent Tutoring Systems \{This document has been constructed from edited excerpts of MITRE Technical Report 92B0000200, Warren, et al.\}

--http://www.mitre.org/resources/centers/advanced_info/g04a/its.html

[JK96] - Menachem Jona and Michael Korkuska. Same Architecture New Domain (SAND): An Alternative Methodology for Building High-Quality Reusable Tutoring Systems. http://www.ils.nwu.edu/ korcuska/Articles/ITS96Sand/Jona-IT96.html

[Jon95] - Menachem "Kemi" Jona. Representing and Re-using General Teaching Strategies: A Knowledge-Rich Approach to Building Authoring Tools for Tutoring Systems. http://www.pitt.edu/ al/aied/jona.html 
[Jon99] - Menachem "Kemi" Jona. Manuscrito: mensagem recebida em novembro de 1999, com referência a http://www.cognitivearts.com

[Kar95] - Even-André Karlsson. Software Reuse - A Holistic Approach. Wiley Series in Software Based systems, 1995.

[Kas94] - Alex Kass. The Casper Project: Integrating Simulation, Case Presentation, and Socratic Tutoring to Reach Diagnostic Problem-Solving in Complex Domains. The Intitute for the Learning Sciences, Northwstern University. Evanston, Illinois. March, 1994.

[KB91]- Alex Kass, Eli Blevis. Learning Through Experience: An Intelligent Learning-ByDoing Environment for Business Consultants. Reprinted from Proceedings of the Intelligent Computer Aided Trainng Conference. Houston,TX, 1991.

[Kem95] - R. H. Kemp. Towards Intelligent Authoring Systems for Interactive Learning Environments. Department of Computer Science. Massey University. Palmerston North New Zealand. http://www.pitt.edu/ al/aied/kemp.html

[Kiy97] - Minoru Kiyama, Satomi Ishiuchi, Kayo Ikeda, Masahiko Tsujimoto, and Yoshimi Fukuhara. Authoring Methods for the Web-Based Intelligent CAI System CALAT and its Application to Telecommunicatios Service. In Intelligent Tutoring System Authoring Tools, Pages 44-52. Papers from the 1997 AAAI Fall Symposium. Technical Report FS-97-10. AAAI Press.

[Kiy99]Minoru Kiyama. Manuscrito: mensagem recebida em novembro de 1999, com referência a http://www.calat.com/calat_e/about/index.html.

[KR95] - Randy Kaplan and Denny Rock. New Directions for Intelligent Tutoring in AI Expert Magazine of Artificial Intelligence in Practice, pages 31-40. February 1995.

[LBSM95] - John Liddle, Keith Brown, Alan Slater and Sean MacDonnchadha. Utilising Multiple Training Strategies whithin Intelligent Industrial Training Systems.

http://www.pitt.edu/ al/aied/liddle.html

[LC92] - Jill H. Larkin, Ruth W. Chabay. Computer-Assisted Instruction and Intelligent Tutoring Systems - Shared Goals and Complementary Approach. Lawrence Erlbaum Associates, Inc., Publishers. Hillsdale, New Jersey, 1992. 
[LDE86] - Robert I. Levine, Diane E. Drang, Barry Edelson. Inteligência Artificial e Sistemas Especialistas. Aplicações e Exemplos Práticos. McGraw-Hill, 1986.

[Lin95] - Frank Linton. ITS Research Stages and ITS Authoring Tools, 1995. http://www.pitt.edu/ al/aied/linton.html

[LN97] - Mirla Eliane Pereira Leite, Maria das Graças Volpe Nunes. Sistema Inteligente de Apoio ao Treinamento e ao Ensino (SIATE): proposta de uma arquitetura. http://www.icmc.sc.usp.br/ mdgvnune/sti.html

[Lur96] - Mark Urban-Lurain. An Historic Review in the Context of the Development of Artificial Intelligence and Educational Psychology. http://web.cps.msu.edu/ urban/ITS.htm

[Maj95] - Nigel Major. How Generic Can Authoring Shells Become?

http://www.pitt.edu/ al/aied/major.html

[Mark91] - Mary A Mark. Publications

http://almons.srv.cs.cmu.edu/afs/cs/user/mmbt/www/professional/publications.html

[Mcd93] - John McDermid. Software Engineer's Reference Book. CRC Press, Inc., 1993

[Mur96] - Tom Murray. Having it All, Maybe: Design Tradeoffs in ITS Authoring Tools. http://www.cs.umass.edu/ tmurray/papers/tradeofs/tradeoffs.html

[Murb98] - Tom Murray. Expanding the Knowledge Acquisition Bottleneck for Intelligent Tutoring Systems.

http://www.cs.umass.edu/ tmurray/papers/IJAIEDSpecialIssue/IJAIED_SI_Intro Pt1 Murray .html

[Mur98] - Tom Murray. Authoring Knowledge Based Tutors: Tools for Content, Instructional Strategy, Student Model, and Interface Design. http://www.cs.umass.edu/ murray/papers/JLSEon/JLS96.html

[Mur99] - Tom Murray. Authoring Intelligent Tutoring Systems: An Analyses of the State of the Art. http://www.cs.umass.edu/ murray/papers/ATSummary/AuthTools.html

[Net98] - Clayton Netz. Não Rasgue Dinheiro. Os gastos com treinamento aumentaram dramaticamente no país. A questão: como evitar o desperdício? Exame, $n^{\circ} 12$, pages 122-132, junho de 1998. 
[NTM93] - M.G.V. Nunes, R.S. Takehara and M.D.C. Mendes. A Network-Based Model for Intelligent Tutoring Systems. Anais - X Simpósio Brasileiro de IA, 1993. Pages 277-288.

[NSB91] - Harold F. O'Neil, Jr., Dean A Slawson and Eva L. Baker. Design of a DomainIndependent Problem-Solving Instructional Strategy for Intelligent Computer-Assisted Instruction. In Intelligent Tutoring Systems - Evolutions in Design. Lawrence Erlbaum Associates, Publishers, pages 69-103, 1991.

[Press95] - Roger S. Pressman. Engenharia de Software. McGraw-Hill, 1995.

[RK96] - Steven Ritter and Kenneth R. Koedinger. Towards Lightweight Tutoring Agents. Position Paper for ITS '96 Workshop on Architectures and Methods for Designing CostEffective and Reusable ITSs, Montreal, June $10^{\text {th }} 1996$.

http://lexus.gslis.utexas.edu/ palmquis/courses/project/koedinger.html

[Rog95]-E. Rogers, Y. Kennedy, T. Walton, P. Nelms, I. Sherry. Intelligent Multimedia Tutoring for Manufactoring Education, 1995.

http://fre.www.ecn.purdue.edu/FrE/asee/fie95/4d1/4d12/4d12.htm

[Row95] - Kurt Rowley. Understanding Software Interoperability in a Technology-Supported System of Education. CAUSE/EFFECTIVE Magazine, Volume 18, Number 3, pages 2026,1995 .

[Row96] - Kurt Rowley. Increasing the Effectiveness of ITS Research and Developmente. Position Paper for ITS'96 Workshop on Architectures and Methods for Designing CostEffective and Reusable ITSs. Montreal, June $10^{\text {th }} 1996$. http://advlearn.Irdc.pitt.edu/itsarch/papers/rowley.html

[RS91] - Christopher K. Riesbeck and Roger C. Schank. From Training to Teaching: Techniques for Case-Based ITS. In Intelligent Tutoring Systems - Evolutions in Design. Lawrence Erlbaum Associates, Publishers, pages 177-193, 1991.

[SB82] - D. Sleeman and J. S. Brown. Intelligent Tutoring Systems. Academic Press, Inc. 1982.

[Sch] - Roger Schank. What We Learn When We Learn By Doing. ILS Technical Report. Number 60. http:// techreport.ils.nwu.edu/tr60.html 
[Sch97] - Roger Schank. Virtual Learning - A Revolutionary Approach to Building a Highly Skilled Workforce. McGraw-Hill, 1997.

[SKJ] - Roger C. Schank, Michael Korkuska and Menachem Jona. Multimedia applications for education and training: Revolution or Trojan Horse?

[SM95] - Luigi Sarti, Kris Van Marcke. Reuse in Intelligent Courseware Authoring. http://www.pitt.edu/ al/aied/sarti_vm.html

[Smi98] - Serengul Smith. Tutorial on, 1998.

http://www.cs.mdx.ac.uk/staffpages/serengul/table.of.contents.htm

[Spa99] - Randall Sparks. Manuscrito: mensagem eletrônica recebida em setembro de 1999.

[Swi91] - Kathleen M. Swigger. Managing Communicatoin Knowledge. In Intelligent Tutoring Systems - Evolution in Design. Lawrence Erlbaum Associates, Publishers, pages 1334,1991 .

[Szm93] - Ricardo Szmit. Programação Orientada para Objeto. Livros Técnicos e Científicos Editora, 1993.

[Tam96] - E. K. Tam, P. Allard, M. Faraj, M. Kaddoura, A. Mourad, H. Liu, A.S. Malowany, R.J. Marceau, L.Granger, J. Gagnon. WITS: A Reusable Architecutre for a VR-Based ITS. Position Paper for ITS'96. Workshop on Architecutres and Methods for Designing CostEffective and Reusable ITSs, Montreal, June $10^{\text {th }}$ 1996. http://advlearn.Irdc.pitt.edu/itsarch/papers/tam.html

[VG96] - Rosa Maria Viccari e Lucia Maria Martins Giraffa. Sistemas Tutores Inteligentes: abordagem tradicional $\mathrm{x}$ abordagem de agentes. XIII SBIA Simpósio Brasileiro de Inteligência Artificial. SBC - Sociedade Brasileira de Computação Tutorial - T6, 1996.

[Wu96] - Binghui Helen Wu. Towards Building Cost-Effective and Reusable ITS - A Computational Approach. Position Paper for ITS'96. Workshop on Architecutres and Methods for Designing Cost-Effective and Reusable ITSs, Montreal, June $10^{\text {th }} 1996$. http://www.eecs.lehigh.edu/ bhw2/

[WW95] - Pamela J. Woods and James R. Warren. Generating Tutoring Systems with Versatile Teaching Strategies. Advanced Computer Research Centre. http://www.pitt.edu./ al/aied/woods.html 
[WW96] - Pamela J. Woods and James R. Warren. Adapting Teaching Strategies in Intelligent Tutoring Systems. Position Paper for ITS'96 Workshop on Architectures and Methods for Designing Cost-Effective and Reusable ITS, 1996.

http://advlearn.Irdc.pitt.edu/its-arch/papers/woods.html

[YC96] - Kwok-Keung Yum, John R. Crawford. On the Feasability of na Interoperable Tutorial Machine to Support the Development and Delivery of Teaching. Position Paper for ITS'96 Workshop on Architectures and Methods for Designing Cost-Effective and Reusable ITSs, Montreal, June $10^{\text {th }} 1996$. http://advlearn.lrdc.pitt.edu/its-arch/papers/yum.html 